\title{
Assistência clínica materna e neonatal às diferentes condições obstétricas em bovinos da raça Holandesa
}

Dissertação apresentada ao Programa de Pós-Graduação em Reprodução Animal da Faculdade de Medicina Veterinária e Zootecnia da Universidade de São Paulo, para obtenção do título de Mestre em Medicina Veterinária

Departamento:

Reprodução Animal

Área de concentração:

Reprodução Animal

Orientadora:

Profa. Dra. Camila Infantosi Vannucchi 
Autorizo a reprodução parcial ou total desta obra, para fins acadêmicos, desde que citada a fonte.

DADOS INTERNACIONAIS DE CATALOGAÇÃO-NA-PUBLICAÇÃO

(Biblioteca Virginie Buff D’Ápice da Faculdade de Medicina Veterinária e Zootecnia da Universidade de São Paulo)

Rodrigues, Jaqueline Aguiar

FMVZ

Assistência clínica materna e neonatal às diferentes condições obstétricas em bovinos da raça Holandesa / Jaqueline Aguiar Rodrigues. São Paulo : J. A. Rodrigues, 2008.

$94 \mathrm{f}$ : : il.

Dissertação (mestrado) - Universidade de São Paulo. Faculdade de Medicina Veterinária e Zootecnia. Departamento de Reprodução Animal, 2008.

Programa de Pós-Graduação: Reprodução Animal.

Área de concentração: Reprodução Animal.

Orientador: Profa. Dra. Camila Infantosi Vannucchi.

1. Parto. 2. Distocia. 3. Bezerro. 4. Hemogasometria. 5. Ocitocina. I. Título. 


\section{UNIVERSIDADE DE SÃO PAULO \\ Faculdade de Medicina Veterinária e Zootecnia \\ Comissão Bioética}

\section{CERTIFICADO}

Certificamos que o Projeto intitulado "Assistência neonatal intra-parto em diferentes condições obstétricas na espécie bovina", protocolado sob o n¹033/2006, utilizando 60 (sessenta) bovinos, sob a responsabilidade da Profa. Dra. Camila Infantosi Vanucchi, está de acordo com os princípios éticos de experimentação animal da Comissão de Bioética da Faculdade de Medicina Veterinária e Zootecnia da Universidade de São Paulo e foi aprovado em reunião do dia 07/02/07".

(We certify that the Research "Bovine neonatal assistance of different obstetrical conditions of calving", protocol number 1033/2006, utilizing 60 (sixty) bovines, under the responsibility Profa. Dra. Camila Infantosi Vanucchi, agree with Ethical Principles in Animal Research adopted by Bioethic Commission of the School of Veterinary Medicine and Zootechny of University of São Paulo and was approved in the meeting of the day $02 / 07 / 2007)$.

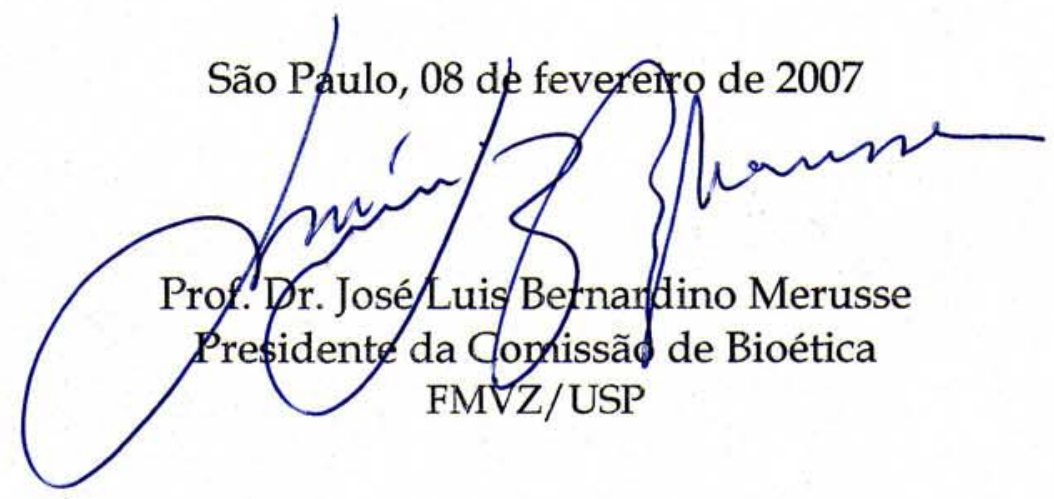




\section{FOLHA DE AVALIAÇÃO}

Nome: RODRIGUES, Jaqueline Aguiar

Título: Assistência clínica materna e neonatal às diferentes condições obstétricas em bovinos da raça Holandesa

Dissertação apresentada ao Programa de Pós-Graduação em Reprodução Animal da Faculdade de Medicina Veterinária e Zootecnia da Universidade de São Paulo para a obtenção do título de Mestre em Medicina Veterinária

Data:

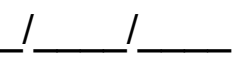

\section{Banca Examinadora}

Prof. Dr.

Instituição:

Assinatura: Julgamento:

Prof. Dr. Instituição:

Assinatura: Julgamento:

Prof. Dr. Instituição:

Assinatura: Julgamento: 


\section{AGRADECIMENTOS}

Gostaria de agradecer, acima de tudo, à minha Família. Mesmo estando cada um de nós em um lugar diferente, sei que estaremos sempre unidos. Mesmo não podendo conviver diariamente juntos, sei que nossos laços não se desfazem. Vocês são minha razão de viver, meus guias, meus alicerces e me conforto a cada día em tê-los ao meu lado e fazer parte de uma históría tão bonita.

Mãe, você é digna deste título. Me deu apoío, conselhos, ajuda; compreendeu certos momentos de ausência e ensinou a todos o que é superar os acontecimentos da vida com força, garra, coragem $e$ elegância. Mostrou-me o que é enfrentar o dia-a-día com segurança $e$ poder se emocionar nas horas tristes. A cada dia você nos surpreende, pois tem aflorado esse seu lado aventureiro, decidido e inteligente. Continue sempre assim, minha mãe!! Te amo muito.

Pai, teus ensinamentos, idéias, conselhos e programações foram essenciais nesta jornada. Você sempre me fez ter garra e vontade de batalhar pelo meu futuro. Tê-lo como exemplo de sucesso é um orgulho para mim. Nunca deixarei de te amar, mesmo longe. Obrigada por tudo que me ensinou e sei que agora posso seguir em frente.

Joana e Ju, vocês são írmãs maravilhosas. Amigas e companheiras eternas que me dão força no que for preciso. Sempre me apoiando ou aconselhando nos principais acontecimentos de nossas vidas. Obrigado pela experiêncía e dedicação de vocês. Tenho certeza que nossa unía continuará sempre, mesmo a distância. 
$\mathcal{F}$, você faz parte dessa família acima. $\mathcal{E}$ indescritivel todos os momentos que passamos juntos. Agradeço muito seu apoio não só durante o mestrado, mas durante toda a nossa uníão. Você me traz inspiração, alegria, força de vontade, me instiga a questionamentos, além de me ensinar muito. Sua inteligência, sinceridade e praticidade me contagiam a ser uma pessoa a cada dia methor. Obrigada por sempre estar por perto. Te amo muito!!! Gostaría de agradecer também à sua família (Sílvana, Orlando e Rafael) pela minha segunda casa. Obrigada.

Agradeço com muito carinho, sinceridade e respeito aos meus avós, em especíal minha vó Ida, meus tíos, tías e prímos pela grande família que vocês completam. Sem essa estrutura toda acho que não estaria por aquí.

Camila, não esqueço o día daquela nossa primeira conversa na escadaría do VRAA de Pirassununga. Naquele momento eu não podía imaginar quantas coisas iriam acontecer. O quão intenso sería essa nossa convivência e quanta experiência de vida eu iria adquirir. Além de todos os ensinamentos, não posso deixar de elogiar sua paixão pelo que faz. Você inspira todos ao seu redor; sua dedicação e sabedoría são surpreendentes. Muito obrigado pelos conselhos e por tudo!

Liege, Cris e Gi. Acho que é impossivel descrever tudo que passamos juntas!! Será que o livro ainda saí?!! Se começarmos a descrever todas as emoções e sentimentos vivenciados........ N Nossas conversas, nossa convivência, nossas rísadas e nossas experiências 
juntas ficarão eternamente guardadas comigo. Adoro vocês. Obrigada por toda a ajuda que vocês me deram durante esses anos. Vocês me farão muita falta.

Denise (Piranha) e Carol. Bom, com certeza vocês participaram de um dos melhores acontecimentos deste meu mestrado: almoçar todos os dias com vocês!!! Descobri amigas que farão parte eternamente da minha vida. Cada uma com seu jeitinho diferente, foram me conquístando e me convencendo até em almoçar no bandejão. As conversas e os consethos que vocês me deram foram essenciais para eu estar aquí. Amo vocês demaís...

Ju, Tati, Fer, Ana e Carol, foi muito bom partilhar algumas situações com vocês. $\mathcal{E}$ gratíficante vê-las evoluindo. Sucesso pra vocês sempre. Claudia e Adriano, o que sería de mím sem vocês? Quanta garra e entusiasmo. Muito obrigada pela ajuda. Sereí eternamente grata ao trabalho de vocês.

Gostaria de agradecer ao Prof. $\mathcal{E d} \mathcal{H}$ foffmann Madureira pelo apoio durante a fase de treinamento e conselhos durante todos esses anos. Ao Fernando Pardo pela árdua ajuda nas madrugadas frías de Pirassununga. Ao Henderson, pela indicação da Fazenda Agríndus.

Agradeço à Valéría, ao flávio (Chaguita), ao Marcílio Nichi e ao Zé Nélio pela colaboração nas análises estatísticas. $\mathcal{E}$ aos demais colegas e professores do Departamento de Reprodução Animal da

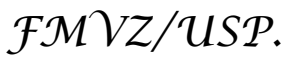


À Fazenda Agrindus: obrigada a todos os funcionários que de alguma forma me ajudaram na realização do experimento, em especial o Sr. Tonho. Obrigada pelas paçocas, refrigerantes e histórias mil.......Agradeço imensamente ao apoío do $\mathcal{M} . \mathcal{V}$. Carlos Alberto Rodrigues $(S \mathcal{A M} \mathcal{V E T})$ e ao Sr Roberto Jank Junior pela disponíbilização do local e dos animaís. Espero ter contribuído para o avanço de vocês.

À Universidade de São Paulo (USP) e à Faculdade de Medicina

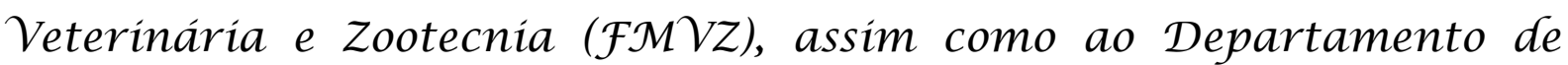
Reprodução Animal (VRA), pela oportunidade de estudo e crescimento. Muito obrígada ao Laboratório de Dosagens Hormonais (LDH-FMVZ/USP) e à Príscila V. Furtado pelas análises hormonaís.

$\grave{\mathcal{A}}$ Prefeitura do Campus $\mathcal{A}$ dministrativo de Pirassununga (PCAPS), pelo apoio e reestruturação necessáría à fase inicial do projeto.

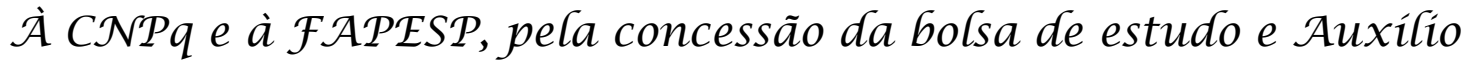
pesquisa.

Agradeço a todos aqueles que de alguma forma colaboraram e participaram na concretização deste trabalho. 
"A mente que se abre a uma nova idéia jamais voltará ao seu tamanho original"

ACbert Finstein

"Para fazer uma obra de arte não basta ter talento, não basta ter força, é preciso também viver um grande amor" 


\section{RESUMO}

RODRIGUES, J. A. Assistência clínica materna e neonatal às diferentes condições obstétricas em bovinos da raça Holandesa. [Maternal and neonatal clinical assistance under distinct obstetrical conditions in Holstein cattle]. 2008. $94 \mathrm{f}$. Dissertação (Mestrado em Medicina Veterinária) - Faculdade de Medicina Veterinária e Zootecnia, Universidade de São Paulo, São Paulo, 2008.

Com o avanço de novas biotécnicas da reprodução (TE, FIV e Clonagem), exige-se o controle mais acurado da gestação e do parto, em razão dos problemas obstétricos decorrentes do nascimento de produtos com crescimento exacerbado ou com menor vitalidade por disfunções placentárias. Desta forma, a redução da mortalidade neonatal justifica-se por acompanhar o aprimoramento na área, visando ao bem-estar materno e neonatal, como também aos interesses do mercado pecuário. As distocias podem comprometer o fluxo sangüíneo materno-fetal e a ocitocina utilizada como agente ecbólico nas atonias uterinas pode aumentar o estresse do parto. Os objetivos deste estudo foram: identificar alterações do escore Apgar de vitalidade neonatal, temperatura corpórea, hemogasometria arterial, glicemia e cortisol ao nascimento e 1 hora pós-parto de neonatos nascidos em distintas condições obstétricas e verificar modificações da pressão arterial (PA), freqüência cardíaca, eletrocardiograma, glicemia e cortisol de vacas no pré-parto, intra-parto, pós-parto imediato e após 1 hora. Foram utilizadas 30 fêmeas bovinas e 30 bezerros da raça Holandesa subdivididos em: Grupo Eutocia (G EUT; $n=10$ ); Grupo Distocia com extração fetal forçada moderada a intensa (G DIST; n=10) e Grupo Atonia ou hipotonia uterina com infusão de Ocitocina (50UI) (G OCT; n=10). As vacas apresentaram hiperglicemia de estresse apenas 1 hora pós-parto no G EUT e G OCT, no entanto, já no intra-parto no G DIST. A distocia também elevou os níveis de cortisol no pós-parto imediato. Houve acréscimo significativo da PA no intra-parto do GDIST, decorrente de contrações uterinas e abdominais mais intensas. Os traçados eletrocardiográficos denotaram ritmo sinusal normal em todos os períodos. Os resultados demonstram adaptação hemodinâmica materna frente às alterações do parto, mesmo com infusão exógena de ocitocina. Os neonatos do G DIST ao nascimento apresentaram menor vitalidade (escore Apgar) e maior estresse (nível de cortisol) em relação aos demais grupos. Os bezerros 
apresentaram normotermia, a despeito da redução da temperatura corpórea 1 hora pós-parto, e mantiveram-se normoglicêmicos. Ainda, os valores de base-excess, $\mathrm{HCO}_{3}{ }^{-}$e $\mathrm{pO}_{2}$ eram baixos, enquanto os níveis de Anion-gap e $\mathrm{pCO}_{2}$, elevados. No entanto, apenas no G DIST observou-se acidose mista (metabólica e respiratória) evidente $(\mathrm{pH}<7,20)$, indicando maior grau de sofrimento fetal e redução do suprimento sangüíneo durante o parto. Os bezerros do G OCT apresentaram $\mathrm{pCO}_{2}$ superior e $\mathrm{pO}_{2}$ inferior aos demais grupos ao nascimento. A infusão de ocitocina pode promover padrões de contração uterina diferenciados, comprometendo ainda mais a oxigenação fetal. A ocitocina alterou momentaneamente as variáveis hemodinâmicas maternas com possível efeito bradicárdico e hipotensor intra-parto, promovendo menor adaptabilidade respiratória neonatal e, portanto, impondo assistência mais criteriosa ao nascimento. Todos os bezerros apresentaram reduzidos valores de hematócrito e hemoglobina, em decorrência da eritropoiese imatura e intensa metabolização de eritrócitos fetais. Após 60 minutos de vida, os bezerros apresentaram recuperação satisfatória do desequilíbrio ácido-base e capacidade evidente de termorregulação e manutenção glicêmica. A condição obstétrica ao nascimento é crítica para o desempenho clínico do neonato, comprometendo sua vitalidade inicial e influenciando a circulação materno-fetal nos casos de distocias. As alterações circulatórias maternas ocasionadas pela ocitocina são consideradas momentâneas, reversíveis e não comprometeram o êxito neonatal.

Palavras-chave: Parto. Distocia. Bezerro. Hemogasometria. Ocitocina. 


\begin{abstract}
RODRIGUES, J. A. Maternal and neonatal clinical assistance under distinct obstetrical conditions in Holstein cattle. [Assistência clínica materna e neonatal às diferentes condições obstétricas em bovinos da raça Holandesa]. 2008. 94 f. Dissertação (Mestrado em Medicina Veterinária) - Faculdade de Medicina Veterinária e Zootecnia, Universidade de São Paulo, São Paulo, 2008.
\end{abstract}

The novel reproductive biotechnologies (ET, IVF and Cloning) require more accurate control of pregnancy and parturition, due to obstetrical problems as a result of the large offspring syndrome or reduced calf vitality associated with placental anomalies. Hence, the reduction in neonatal mortality is justifiable as research in this area progresses, aiming maternal and neonatal well-being and livestock economic concernment. Dystocia may compromise dam-fetal blood flow and induces severe hypoxia at birth. Oxytocin employed as ecbolic treatment for uterine inertia can enhance calving stress. Therefore, the aims of this study were to identify abnormalities in neonatal Apgar score, body temperature, arterial blood gas analysis, glucose and cortisol assay at birth and after 1 hour of calving under distinct obstetrical conditions and to verify the changes on blood pressure (BP), heart rate, electrocardiogram record, glucose and cortisol assay of cows during the first stage of labor, intra-partum, immediately after calving and 1 hour later. Thirty Holstein cows and 30 Holstein calves were grouped according to the obstetrical condition into: Eutocia Group (EUT G; n=10); Dystocia Group with mild to severe obstetric assistance (DIST G; n=10) and Uterine Inertia Group treated with oxytocin (50UI) (OCT G; n=10). EUT G and OCT G cows showed stress-induced hyperglycemia 1 hour after calving. On the other hand, DIST G presented hyperglycemia yet during intra-partum. Dystocia also increased cortisol levels shortly after calving. During labor, DIST G presented significantly higher BP, due to uterine and abdominal strengthened contractions. Electrocardiogram recordings denoted normal sinus rhythm at all time points. DIST G neonates presented lower vitality (Apgar score) and higher stress (cortisol level) at birth compared to other groups. Calves were normothermic, despite the significative decrease in body temperature after 1 hour of birth, and remained normoglycemic. Moreover, base-excess, $\mathrm{HCO}_{3}{ }^{-}$and $\mathrm{pO}_{2}$ results were low, while Anion-gap and $\mathrm{pCO}_{2}$ were high, comparing to standard values. 
However, mixed acidosis (metabolic and respiratory; $\mathrm{pH}<7,2$ ) was only noticeable in DIST G, suggesting higher fetal distress during calving and reduced blood supply (oxygenation). In addition, OCT G calves presented increased $\mathrm{pCO}_{2}$ and decreased $\mathrm{pO}_{2}$ at birth. Oxytocin infusion may cause a distinct pattern of uterine contraction, compromising neonatal hypoxia even more. The oxytocin infusion altered transitorily the maternal hemodynamic variables with a possible bradicardiac effect and intrapartum hypotension, causing lower neonatal respiratory adaptability, demanding more intensive care at birth. All newborns showed low hematocrit and hemoglobin concentration due to immature erythropoiesis and intense fetal erythrocyte metabolism. The present results indicate full maternal adaptation to labor's requirement. Calves showed stark acid-base recovery during the critical period of adaptation to ex utero life, with also evident thermoregulation and glucose maintenance 1 hour after birth. The obstetrical condition presented at birth was determinant to neonatal clinical demeanor. Dystocia mainly compromised blood flow and oxygen supply and ultimately interfered with newborn vitality. Ponctual maternal circulatory alterations caused by oxytocin infusion were reversible and did not compromise neonatal outcome.

Keywords: Calving. Dystocia. Calf. Blood gas analysis. Oxytocin. 


\section{LISTA DE ABREVIATURAS}

\begin{tabular}{|c|c|}
\hline $\mathrm{ADH}$ & Hormônio anti-diurético \\
\hline Apgar & Escore de vitalidade Apgar \\
\hline $\mathrm{BE}$ & Base Excess - Base-tampão total \\
\hline BUN & Uréia nitrogenada sangüínea \\
\hline $\mathrm{Cl}^{-}$ & Íon cloro \\
\hline $\mathrm{FC}$ & Freqüência cardíaca \\
\hline FR & Freqüência respiratória \\
\hline G DIST & Grupo distocia \\
\hline G EUT & Grupo eutocia \\
\hline G OCT & Grupo ocitocina \\
\hline $\mathrm{Hb}$ & Hemoglobina \\
\hline $\mathrm{HCO}_{3}^{-}$ & Íon bicarbonato \\
\hline $\mathrm{Ht}$ & Hematócrito \\
\hline $\mathrm{K}^{+}$ & ĺon potássio \\
\hline $\mathrm{Na}^{+}$ & Íon sódio \\
\hline${ }^{\circ} \mathrm{C}$ & Graus Celsius \\
\hline PA & Pressão arterial não-invasiva \\
\hline $\mathrm{pCO}_{2}$ & Pressão parcial de dióxido de carbono \\
\hline $\mathrm{pO}_{2}$ & Pressão parcial de oxigênio \\
\hline $\mathrm{SO}_{2}$ & Saturação de oxigênio \\
\hline $\mathrm{TCO}_{2}$ & Dióxido de carbono total \\
\hline Temp & Temperatura corpórea \\
\hline
\end{tabular}




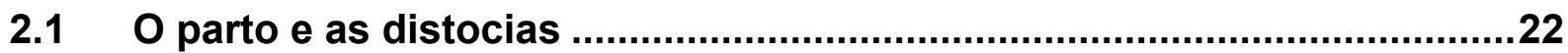

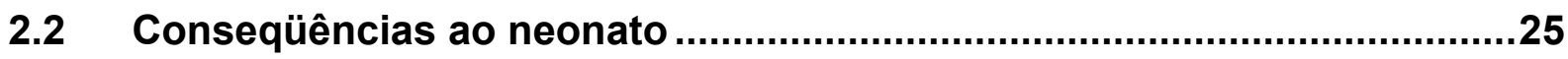

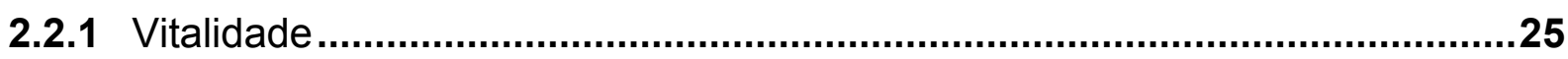

2.2.2 Hemogasometria e o equilíbrio eletrolítico...............................................28

2.3 Conseqüências maternas ........................................................................

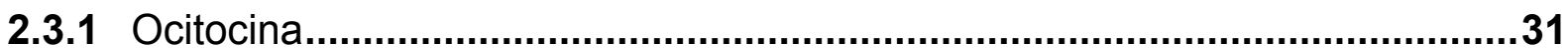

2.3.2 Efeitos Hemodinâmicos ..........................................................................33

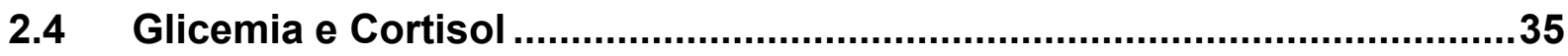

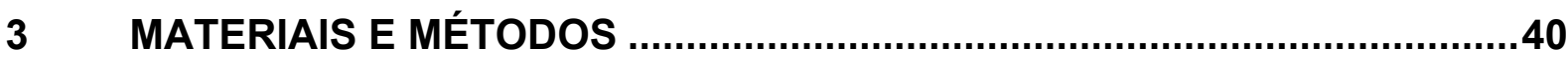

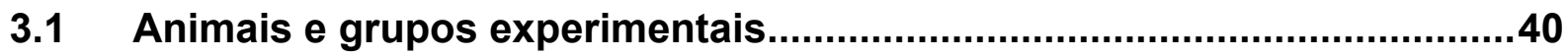

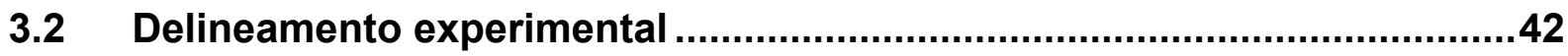

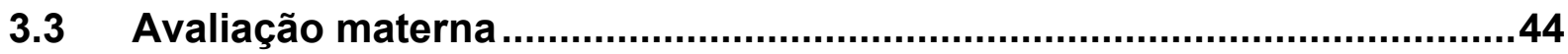

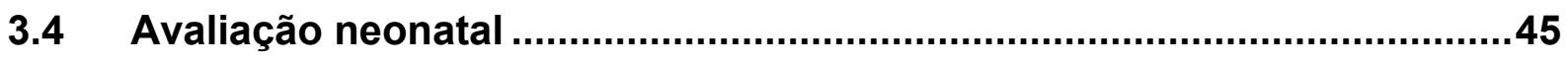

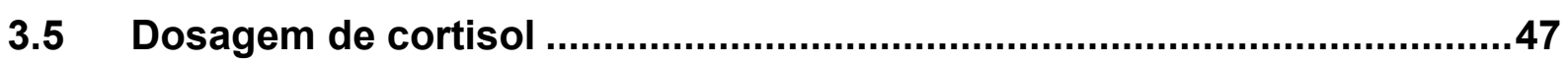

3.6 Valores de referência ......................................................................

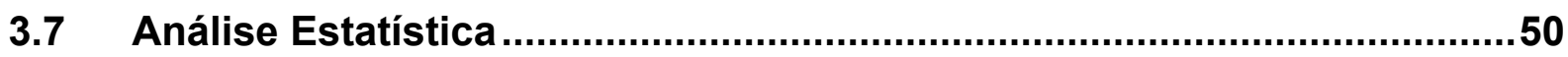

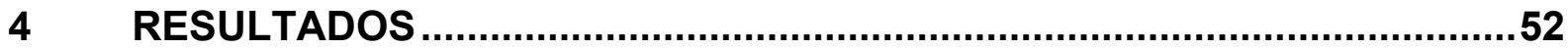

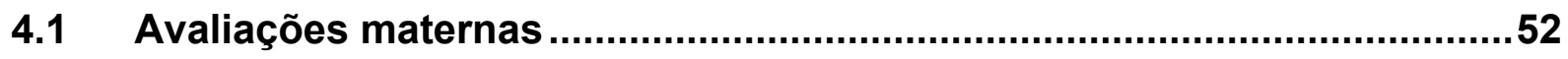

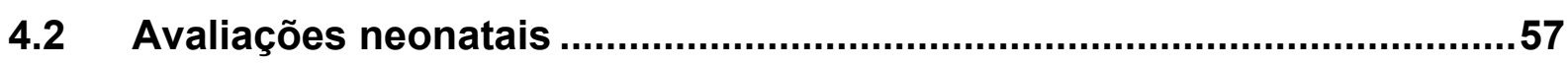

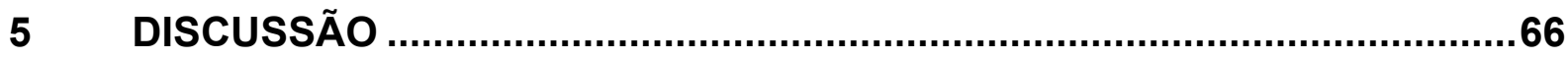


5.1 Alterações hemodinâmicas maternas .....................................................66

5.2 Vitalidade neonatal (Escore Apgar e Temperatura corpórea) ..................69

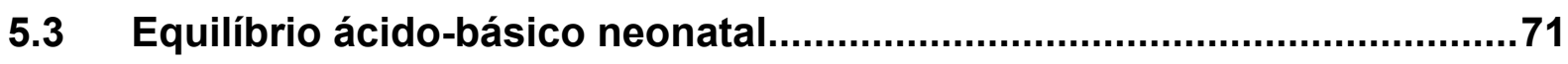

5.4 Glicemia e cortisol materno e neonatal ....................................................75

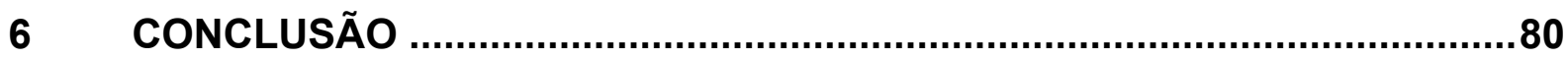

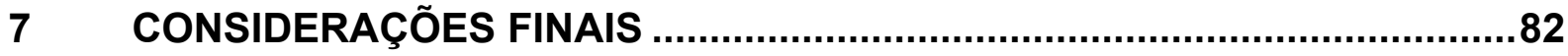

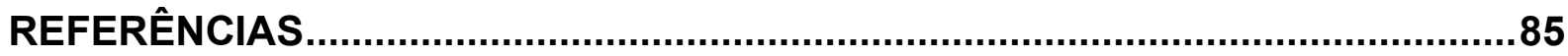


Introdução 


\section{INTRODUÇÃO}

A ciência que estuda as duas primeiras semanas de vida é a Neonatologia. Neste período, são necessárias constantes adaptações ao meio extra-uterino, já iniciadas ao final da gestação com a maturação fetal. Os neonatos quando possuem cuidados maternos direcionados, em geral, não requerem assistência médica específica. Entretanto, com o intuito de melhor controlar a higidez e a taxa de sobrevivência nesta fase transitória, faz-se necessária adequada supervisão. Porém, o paciente, neste contexto, possui características peculiares e em parte desconhecidas, as quais não podem ser negligenciadas frente aos avanços da Medicina Veterinária.

As espécies animais de produção podem gerar, em determinadas circunstâncias, exemplares de grande valor zootécnico, principalmente com o avanço das novas biotécnicas da reprodução. A transferência de embriões, fecundação in vitro e imprescindivelmente a clonagem e transgenia são técnicas para as quais é exigido o controle mais acurado da gestação e parto, em razão do nascimento de produtos com crescimento exacerbado ou de menor vitalidade por disfunções placentárias. Desta forma, o controle da mortalidade neonatal justifica-se como forma de acompanhar o aprimoramento na área, visando ao bem-estar materno e dos recém-nascidos, como também aos interesses do mercado pecuário.

De acordo com Davidson (2003), a mortalidade neonatal possui diferentes causas, entre elas: ambiente desfavorável, enfermidades infecciosas e parasitárias, defeitos congênitos ou genéticos, desnutrição, condições inadequadas de saúde materna, falhas de assistência ao parto, bem como distocias. O parto laborioso tem grande impacto nas produções comerciais, sendo responsável por $41 \%$ das perdas econômicas, principalmente por baixa fertilidade e morbidade da matriz, e mortalidade de bezerros (MEE, 2008).

Em obstetrícia bovina, o momento exato para proceder à assistência médica, com o intuito de preservar a vida fetal, é ainda indeterminado. A duração do segundo estágio do parto em vacas é variável e os sinais de distocia podem ser discretos e imperceptíveis clinicamente. A intervenção obstétrica precoce pode causar danos ao feto e ao canal do parto, por haver ainda inadequada dilatação cervical. No entanto, 
o retardo para o auxílio médico pode comprometer a vida fetal pelo estabelecimento de quadros de hipóxia, hipercapnia e acidose. A presença de mecônio e a perda de reflexos fetais são sinais de asfixia intra-uterina, mas são indícios tardios e imprecisos para estimar o grau de acidose fetal (BLEUL et al., 2008).

As principais alterações do período neonatal decorrem da hipóxia por alterações na circulação útero-placentária e distúrbios do cordão umbilical durante as contrações uterinas intensas e prolongadas (SIRISTATIDIS et al., 2003). A força das contrações e a pressão sobre a região pélvica criam um ambiente de acidose e hipóxia fetal, evitado por intervenções assistenciais, tais como a correção obstétrica manual ou mesmo a episiotomia. Tais condutas podem restabelecer as funções vitais respiratória, cardiovascular, termo-regulatória e metabólica dos neonatos (RICE, 1994). A asfixia prolongada ou intermitente in utero e durante o parto resulta em menor vitalidade do neonato e diminui sua capacidade de adaptação à vida extra-uterina (HERPIN et al., 1996). Os neonatos provenientes de partos laboriosos apresentam maiores riscos de seqüelas neurológicas posteriores, em função da acidose decorrente do metabolismo anaeróbio durante a hipóxia (NORÉN et al., 2003).

A distocia materna por deficiências de contração uterina em bovinos é normalmente corrigida por manobras obstétricas. A extração forçada instituída nestas situações pode auxiliar a expulsão fetal, mas é considerada um procedimento obstétrico com riscos tanto para mãe como para o bezerro. Uma das principais abordagens para indução de contrações nos casos de inércia uterina é a administração parenteral de agentes ecbólicos, principalmente a ocitocina (JOHNSTON et al., 2001). Por outro lado, Mukaddam-Daher et al. (2001) demonstraram que a ocitocina participa também de regulações endócrinas e neuroendócrinas de órgãos como o coração e rins. Portanto, partos induzidos com a administração de ocitocina exógena podem levar ao comprometimento fetal por hipotensão e bradicardia materna, além de potencializar o estresse durante o parto.

As alterações da gasometria sangüínea em neonatos nascidos sob diferentes condições obstétricas ainda não foram plenamente determinadas em Medicina Veterinária, embora seja um recurso diagnóstico utilizado rotineiramente para a acidose neonatal em Medicina. Ainda, em Neonatologia Humana, a vitalidade dos recém-nascidos é avaliada pelo escore Apgar (OLIVEIRA, 1999), porém este possui 
poucas referências de aplicação em espécies animais.

Em face do exposto, foram objetivos deste estudo:

1) Verificar os efeitos da distocia corrigida por manobras obstétricas ou por emprego da ocitocina para indução de contrações uterinas sobre variáveis hemodinâmicas maternas (pressão arterial não-invasiva; freqüência cardíaca e eletrocardiograma).

2) Identificar alterações clínicas e subsidiárias de neonatos nascidos em distocia assistida ou da administração de ocitocina.

3) Comparar as distintas condições obstétricas (eutocia, distocia com correção manual e distocia com tratamento ecbólico) em relação ao grau de estresse materno e neonatal gerado no momento do parto.

4) Estabelecer parâmetros laboratoriais ainda inexistentes para sangue arterial de bezerros nascidos em eutocia e clinicamente hígidos. 
Revisão de Literatura 


\section{REVISÃO DE LITERATURA}

Ao se comparar com os progressos da medicina preventiva e curativa nas mais diversas áreas da Medicina Veterinária, a neonatologia tem sido minimamente estudada. Explica-se tal situação por limitações médicas frente à rápida evolução clínica das afecções neste período e pela dificuldade na obtenção e interpretação de exames complementares.

Nas espécies domésticas, excluindo-se eventuais distúrbios durante o parto, os neonatos sobrevivem à fase transitória sem aprimorada assistência médica (NOAKES, 2001). Todavia, sob condições ambientais adversas e especialmente em neonatos debilitados, são de extrema importância a adequada supervisão e assistência durante o período neonatal. A correta conduta médica durante o periparto, principalmente frente a complicações, também é determinante para as diferentes causas de mortalidade neonatal e natimortalidade. Nos últimos anos, o avanço tecnológico dos sistemas produtivos tem ocorrido rapidamente, em detrimento das adaptações animais. Por exemplo, estudos das afecções de parto na espécie bovina são minimamente conduzidos, em comparação às pesquisas clínicas de maior prevalência nos rebanhos (MEE, 2008) e ao emprego dos métodos de seleção de reprodutores.

\subsection{O parto e as distocias}

O parto é definido como um processo fisiológico no qual o feto e seus envoltórios são eliminados do útero gravídico pela dilatação das vias de expulsão fetal e por meio do desencadeamento de contrações uterinas e abdominais (LANDIM-ALVARENGA, 2006). A eutocia ou parto normal é um processo espontâneo, que ocorre no momento apropriado da gestação (MEE, 2008) e compreende 3 fases ou estágios. O primeiro é denominado pródromos e inicia-se com as contrações uterinas de baixa freqüência e amplitude e dilatação cervical, podendo durar cerca de 6 a 16 horas. O segundo estágio tem início com a 
insinuação de apêndices fetais no canal de parto, culminando com a ruptura da bolsa alantoideana e/ou amniótica. Desta forma, são desencadeados reflexos para as contrações abdominais, as quais aumentam em força e freqüência até a expulsão fetal. A fase expulsiva pode durar de 1 a 3 horas em bovinos, podendo chegar a 6 horas nas primíparas. O terceiro estágio envolve a expulsão dos anexos fetais por até aproximadamente 8 horas (LANDIM-ALVARENGA, 2006).

O parto assistido é aquele para o qual é necessário auxílio externo, sem necessariamente resultar em complicações posteriores (MEE, 2008). A intervenção ou assistência ao parto deve ocorrer respeitando critérios pré-estabelecidos: prolongamento do primeiro estágio do parto; segundo estágio em progresso lento ou ausente após 2 horas; protusão da bolsa amniótica não acompanhada de expulsão fetal após 2 horas e membranas fetais retidas por 8 a 12 horas (MORTIMER; TOOMBS, 1993).

A distocia é definida como parto difícil ou laborioso, resultando em parturição prolongada ou extração fetal forçada (MEE, 2008) e reduzida viabilidade do neonato ou danos maternos (RICE, 1994). A ocorrência de distocia está relacionada à inabilidade para expulsão fetal por alterações maternas ou fetais. A distocia de origem materna pode apresentar diferentes causas funcionais: distúrbios de contrações, vícios pélvicos, estenoses vaginais e vulvares, alterações morfológicas do colo uterino e deslocamentos uterinos (JOHNSTON et al., 2001). A distocia de origem fetal é ocasionada geralmente por alteração na estática fetal, gigantismo ou hidropsia fetal, anomalias do cordão umbilical, resistência das membranas fetais ou retrações musculares (NOAKES, 2001).

Mundialmente, a incidência de distocia em rebanhos bovinos leiteiros é menor do que $5 \%$, mas a taxa de partos assistidos varia entre 10 a $50 \%$ (MEE, 2008). Segundo levantamento de Esslemont e Peeler (1993), a taxa de distocia pode alcançar 9,5\%. A distocia em fêmeas da espécie bovina é responsável por $40 \%$ da mortalidade neonatal durante as primeiras 24 horas de vida (PATTERSON et al., 1987) e reduz para apenas $85 \%$ a taxa de sobrevivência até o desmame (ARTHUR et al., 2000). De acordo com Riley et al. (2004), bezerros nascidos em distocia são mais fracos ao nascimento e tem probabilidade de óbito 13 vezes maior antes do desmame.

Nos rebanhos de corte, a incidência de distocia em primíparas é de $17 \%$ e em 
pluríparas, apenas 4\%. Destes índices, menos de 1\% tem como causa os distúrbios da estática fetal, $28 \%$ exigem leve tração manual e 69\% necessitam de intensa força de extração. Aproximadamente $3 \%$ das fêmeas são submetidas à cesariana e destas, metade dos neonatos apresenta êxito letal (NIX et al., 1998). Segundo dados de Arthur et al. (2000), a incidência de distocia em novilhas Angus é de 7\% e implica em mortalidade de $1 \%$ dos bezerros, acarretando perda econômica significativa para o produtor.

Em rebanhos de corte norte-americanos, a taxa de mortalidade neonatal relatada é de $4,5 \%$, tendo como principais causas: as distocias $(17,5 \%)$, natimortalidade $(12,4 \%)$, hipotermia $(12,2 \%)$, diarréia $(11,5 \%)$ e infecções respiratórias (7,6\%) (WITTUN et al., 1993). De acordo com Wikse et al. (1994), a mortalidade neonatal pode variar de 5 a $10 \%$ antes da primeira mamada. Entre 50 a $70 \%$ da mortalidade neonatal ocorre nos primeiros 3 dias de vida, sendo a distocia, inanição e hipotermia responsáveis por 50 a 60\% destas perdas (PATTERSON et al., 1987).

As alterações do período periparto acarretam custos adicionais ao produtor, representados por gastos médicos, horas extras de trabalho, medicamentos e o próprio valor da carcaça do animal. A magnitude dos efeitos subseqüentes da distocia na produtividade do rebanho está relacionada a sua incidência e severidade. As principais conseqüências maternas evidenciadas posteriormente são a redução da produção leiteira e diminuição do desempenho reprodutivo pós-parto, com diminuição na taxa de concepção (ARTHUR et al., 2000; VAALA et al., 2006).

Em relação ao índice total de mortalidade em bezerros, 59\% dos casos decorrem do parto de fêmeas primíparas (PATTERSON et al., 1987). Segundo Cain e Dennis (1987), a maior incidência de distocia é realmente no primeiro parto de novilhas, sendo a incompatibilidade feto-pélvica a causa mais comum. Normalmente, as novilhas de reposição de plantel ainda não atingiram a estrutura corpórea ideal necessária ao parto espontâneo (ODDE, 1988). As principais causas de distocia em primíparas são: desproporção feto-pélvica, estática fetal anormal e estenose vulvar. Nas pluríparas, as distocias decorrem majoritariamente de alterações na estática fetal, seguida de incompatibilidade materno-fetal, múltiplos fetos, inércia uterina, torção uterina e estenose cervical (MEE, 2008).

A taxa de mortalidade neonatal nas primeiras 24 horas após o parto é influenciada principalmente pelo grau de dificuldade no parto e a paridade das 
fêmeas (MANGURKAR et al., 1984; NIX et al., 1998). Os bezerros machos predispõe ao nascimento sob condições de distocia e, portanto, são responsáveis por taxas de mortalidade $4 \%$ maior que as fêmeas (RILEY et al., 2004). Ainda, sabese que bezerros nascidos por assistência são significativamente mais pesados do que aqueles nascidos sem auxílio (NIX et al., 1998; ARTHUR et al., 2000). O peso ao nascimento do bezerro é um dos mais importantes fatores que predizem o risco de distocia e sofre influência do período gestacional, número de partos da matriz, gênero dos bezerros, fenótipo dos reprodutores, nutrição materna e uso de biotécnicas reprodutivas (MEE, 2008).

\subsection{Conseqüências ao neonato}

A distocia materna ou fetal está intrinsecamente relacionada ao alto índice de mortalidade neonatal (NOAKES, 2001), pois reduz o suprimento sangüíneo à musculatura, tecido adiposo e órgãos vitais, bem como diminui a capacidade de termorregulação dos neonatos (BELLOWS; LAMMOGLIA, 2000). Segundo Richardson et al. (1993), durante a distocia, há redistribuição da perfusão sangüínea em favor do coração, cérebro e adrenais do feto, em detrimento dos sistemas gastro-intestinal, renal e músculo-esquelético. A distocia grave pode prolongar o período de contrações uterinas e agravar o quadro de hipóxia fetal fisiológico e transitório no parto espontâneo. A hipóxia prolongada acarreta mudanças nos níveis circulantes de glicose e cortisol sérico, reduz o metabolismo da termorregulação e causa danos ao sistema nervoso central e simpático dos recém-nascidos (BELLOWS; LAMMOGLIA, 2000).

\subsubsection{Vitalidade}

A estimativa da higidez dos recém-nascidos é uma grande ferramenta de predição da sobrevivência neonatal (DIESCH et al., 2004). A maioria das afecções do período peri-parto é de aparecimento súbito e sinais clínicos de baixa 
especificidade, tais como: inatividade, fraqueza, retardo em se levantar ou mamar, hipotermia, batimentos cardíacos e movimentos respiratórios com freqüência variável. Os bezerros comprometidos tornam-se fracos e menos responsivos com o passar do tempo, pois os níveis sistêmicos de catecolaminas diminuem após 15 a 30 minutos do parto (LANDIM-ALVARENGA et al., 2006).

Os neonatos são suscetíveis a flutuações da temperatura ambiente e apresentam dificuldade para a homeotermia, pois possuem maior superfície corpórea em relação a sua massa, concomitantemente à evaporação de líquido amniótico da pele e trato respiratório e a limitadas reservas calóricas. A termoneutralidade é, então, mantida pelo reflexo de tremor $(60 \%)$ e pelo metabolismo da gordura marrom (40\%) (VAALA et al., 2006). Os neonatos bovinos nascidos em eutocia ou sob diferentes graus de distocia apresentam reflexo para manter o tremor preservado, mesmo após exposição prolongada ao frio (BELLOWS; LAMMOGLIA, 2000). A resposta de tremor consiste na contração involuntária e periódica dos músculos esqueléticos corpóreos. As camadas musculares adquirem um tônus capaz de manter o balanço térmico, sem a necessidade de movimentos físicos, os quais podem levar à perda de calor. Portanto, bezerros mais fortes e que se levantam rapidamente após o parto tem maior capacidade termorregulatória (CARSTENS, 1994).

Por outro lado, o estresse gerado para manter a homeotermia por longos períodos leva à depleção dos estoques energéticos, indução de fraqueza física e atraso na absorção de imunoglobulinas (CARSTENS, 1994). Portanto, a verificação da temperatura retal ao nascimento é um procedimento clínico de grande valia para prevenção da hipotermia e, conseqüentemente, das altas taxas de mortalidade observadas neste período.

Desenvolvido na Medicina, um dos métodos para a avaliação clínica de recém-nascidos é o sistema Apgar. Primeiramente proposto em 1953, baseia-se na pontuação da freqüência cardíaca e respiratória, tônus muscular, atividade reflexa e coloração de pele ou mucosas, realizada nos primeiros minutos após o parto. 0 escore Apgar é uma ferramenta semiológica de uso rotineiro, pois permite avaliar as principais funções vitais do neonato nos primeiros minutos de vida e indicar a necessidade de medidas preventivas ou curativas. Segundo Yeomans et al. (1985), o escore Apgar pode auxiliar na diferenciação de neonatos hígidos dos severamente 
comprometidos, porém não é sensível suficiente para diferenciar o comprometimento neonatal menos aparente. Tal avaliação pode ser usada para detectar sinais precoces de asfixia periparto e é melhor realizada até 10 a 15 minutos do parto (VAALA et al., 2006).

Em Medicina Veterinária, as referências do sistema Apgar para as diferentes espécies animais são escassas. Benesi (1992) utilizou a adaptação do escore Apgar para neonatos bovinos, a qual julgava por pontos a reação da cabeça, reação ao banho com água fria, reflexo palpebral e interdigital, respiração e coloração de mucosas. Outras adaptações sugerem a avaliação do batimento cardíaco, atividade respiratória, tônus muscular, coloração de mucosas e vocalização ao nascimento (MOON et al., 2001; MOON-MASSAT, 2002). Ainda a auscultação torácica é um importante preditor da higidez dos bezerros, pois a perda do murmúrio cardíaco e ruído respiratório alto são os primeiros sinais de comprometimento neonatal (LANDIM-ALVARENGA et al., 2006). É importante ressaltar que os componentes do escore de vitalidade ou Apgar estimam a sobrevivência neonatal, pois o êxito dos recém-nascidos também está relacionado à sua habilidade termorregulatória e à ingestão de colostro no momento adequado (HERPIN et al., 1996).

Nos bezerros, a tentativa de permanecer em decúbito esternal deve ocorrer em poucos minutos após o parto e possui relação direta com presença de tônus muscular e reflexos podais, indicativos de adequada oxigenação. Por outro lado, a cianose de mucosas pode indicar hipóxia e acidose, com prognóstico de vitalidade ruim (LANDIM-ALVARENGA et al., 2006). Os bezerros em hipóxia são inicialmente alertas, mas não sustentam o decúbito esternal, apresentam reflexo de sucção deprimido ou ausente, retardo na tentativa de permanecer em estação, atividade mental deprimida e bradipnéia (VAALA et al., 2006).

Andres et al. (1999) constataram alta correlação entre as avaliações de neonatos humanos pelo escore Apgar nos primeiros minutos de vida com a hemogasometria. Em recém-nascidos da espécie suína, observou-se maior escore de vitalidade quando as variáveis da hemogasometria e do equilíbrio ácido-base eram favoráveis (HERPIN et al., 1996). 
2.2.2 Hemogasometria e o equilíbrio eletrolítico

Para a completa compreensão dos mecanismos complexos do equilíbrio ácido-básico nos sistemas corpóreos, alguns conceitos fundamentais são necessários. $\mathrm{O} \mathrm{pH}$ é a medida para expressar a concentração de íons $\mathrm{H}^{+}$nos fluidos orgânicos e quando além dos limites compatíveis com a vida $(7,0$ a 7,8$)$, resulta em alterações nas cargas elétricas e mudança na estrutura e função molecular das proteínas. Para a regulação do $\mathrm{pH}$ plasmático existem três mecanismos básicos interdependentes e simultâneos: o tamponamento químico (bicarbonato, hemoglobina, proteínas plasmáticas e fosfato); o equilíbrio respiratório (controle do $\mathrm{H}_{2} \mathrm{CO}_{3}$ e eliminação de $\left.\mathrm{CO}_{2}\right)$; e a excreção renal seletiva de íons $\left(\mathrm{H}^{+}\right.$e $\left.\mathrm{HCO}_{3}{ }^{-}\right)$. O sistema bicarbonato $\left(\mathrm{HCO}_{3}{ }^{-}\right)$consiste na relação entre o ácido carbônico $\left(\mathrm{H}_{2} \mathrm{CO}_{3}\right)$ e sua base conjugada. $\mathrm{O} \mathrm{CO}_{2}$, neste contexto, dá origem ao ácido carbônico (LISBÔA, 2000).

A pressão parcial de oxigênio $\left(\mathrm{pO}_{2}\right)$ e de dióxido de carbono $\left(\mathrm{pCO}_{2}\right)$ indicam suas concentrações no sangue, dissolvidos no plasma ou mesmo ligados à hemoglobina. Desta maneira, o pH sangüíneo pode ser o resultado do equilíbrio entre $\mathrm{O}_{\mathrm{HCO}_{3}}^{-}$e a $\mathrm{pCO}_{2}$ no sangue. Convencionou-se a utilização de dois componentes no balanço dos íons $\mathrm{H}^{+}$: respiratório $\left(\mathrm{pCO}_{2}\right)$ e o metabólico ou básico $\left(\mathrm{HCO}_{3}{ }^{-}\right)$.

No entanto, outras medidas devem ser acrescentadas ao fator metabólico. $O$ bicarbonato sofre influência direta do $\mathrm{CO}_{2}$, podendo ser calculado a partir do $\mathrm{TCO}_{2}$ (dióxido de carbono total). Tal medida refere-se à reserva alcalina, levando-se em consideração que $95 \%$ do conteúdo de $\mathrm{CO}_{2}$ pode ser encontrado nas moléculas de $\mathrm{HCO}_{3}{ }^{-}$. Outra medida metabólica é a do excesso ou déficit de bases (Base excess BE) no sangue, pois representa o acúmulo de ácidos ou bases fortes necessário para o equilíbrio do pH (LISBÔA, 2000). O Anion-Gap considera a diferença entre as concentrações dos principais cátions (sódio e potássio) e ânions (cloreto e bicarbonato) no sangue. Também auxilia na análise dos desequilíbrios ácido-básicos metabólicos que se neutralizam, sem reflexo no $\mathrm{pH}$ sangüíneo. Ainda, possibilita a estimativa da concentração dos chamados ânions não medidos, tais como as proteínas do plasma com cargas negativas (KANETO et al., 2004). 
A acidose ou alcalose metabólica caracterizam-se pela proporção de bases conjugadas a seus ácidos fracos. Já os distúrbios ácido-básicos que envolvem primariamente o aumento ou diminuição anormais da $\mathrm{pCO}_{2}$, provocados por alterações respiratórias, são denominados acidose ou alcalose respiratória, respectivamente (SWENSON; REECE, 1996).

As intensas contrações uterinas durante o parto causam compressão das artérias uterinas e do cordão umbilical, acarretando redução drástica da circulação útero-placentária e umbilical (SIRISTATIDIS et al., 2003). Em partos normais, um curto período de asfixia ocorre, porém resulta em hipercapnia e acidemia transitórias ao neonato (MASSIP, 1980). A redução fisiológica do fluxo sangüíneo da mãe para o feto diminui a pressão de oxigênio $\left(\mathrm{pO}_{2}\right)$ fetal e reflexamente há vasodilatação cerebral e vasoconstrição periférica. Porém, quando a saturação de $\mathrm{O}_{2}$ permanece cronicamente abaixo de $30 \%$, os fetos geralmente não mantém adequada resposta reflexa, em função do metabolismo anaeróbio e da queda no pH sangüíneo (SIRISTATIDIS et al., 2003).

Após o nascimento, o quadro de hipóxia mantém-se no neonato, principalmente por atelectasia pulmonar, reduzido esforço respiratório, adaptação da circulação pulmonar, mistura de sangue venoso e arterial no coração e má difusão de gases nos alvéolos (LANDIM-ALVARENGA et al., 2006). A asfixia fetal é resultante da isquemia do cordão umbilical. Já a asfixia neonatal é decorrente das inadequadas trocas gasosas por imaturidade pulmonar ou do centro respiratório (BLEUL et al., 2007).

Em Neonatologia Humana, a determinação do $\mathrm{pH}, \mathrm{pO}_{2}$ e $\mathrm{pCO}_{2}$, a partir da veia e artéria umbilicais do recém-nascido, são avaliações rotineiras que permitem determinar o grau de acidose metabólica e respiratória e, ainda, predizer a necessidade de cuidados intensivos e correção imediata do distúrbio metabólico (SIRISTATIDIS et al., 2003). Ainda, a mensuração de fatores metabólicos (BE e bicarbonato) permite a identificação de neonatos com maiores riscos para o desenvolvimento de seqüelas da asfixia intra-uterina (ANDRES et al., 1999). A asfixia neonatal impede a troca de gases sangüíneos, levando à progressiva hipoxemia e hipercapnia. A resultante acidose respiratória e metabólica estão associadas à morbidade e morte neonatal (ANDRES et al., 1999).

A saturação de oxigênio abaixo de $30 \%$ induz à glicólise anaeróbia dos tecidos fetais, produzindo como principal metabólito o lactato (LUTTKUS et al., 
2003). Abitbol et al. (1986) verificaram que as alterações nos parâmetros sangüíneos ocorrem posteriormente às teciduais, desta forma, sugerindo que a gravidade do distúrbio metabólico é ainda maior em órgãos nobres como coração, fígado, rins e cérebro.

O componente respiratório da acidose é dificilmente avaliado em sangue venoso. Um dos recursos utilizados para avaliar a função pulmonar é a determinação de $\mathrm{pO}_{2}$ e $\mathrm{pCO}_{2}$ arteriais. Poucos estudos foram conduzidos em bezerros no período neonatal imediato utilizando-se a análise de sangue arterial e a condição obstétrica em questão (BLEUL et al., 2007). Em leitões, a forma de apresentação fetal no canal de parto tem relação direta com o grau de asfixia. A apresentação posterior determina acréscimo na concentração de lactato sangüíneo e acidose quando comparada à apresentação anterior, além da intensa condição de estresse durante o parto (HERPIN et al., 1996).

Os eletrólitos participam de funções teciduais e da composição de fluidos corporais. Os íons sódio, potássio e cloreto são essenciais aos sistemas orgânicos, pois atuam na condução de estímulos nervosos, na contração muscular, manutenção e controle da volemia, no equilíbrio ácido-básico e em múltiplas reações metabólicas (COELHO, 2002). O sódio é o principal cátion do fluido extra-celular e participa ativamente do equilíbrio ácido-básico. Sua principal via de excreção é a renal, o que regula o volume plasmático normal, essencial para a perfusão adequada dos tecidos. O potássio é o principal cátion intra-celular, podendo ser reabsorvido ou excretado via renal na dependência de íons $\mathrm{H}^{+}$e do estado ácidobase. Já os cloretos acompanham os teores de sódio para a manutenção do equilíbrio hídrico corporal. Com relação aos desequilíbrios ácido-básicos, são proporcionais e opostos às taxas de bicarbonato sangüíneo (COELHO, 2002).

A uréia nitrogenada sangüínea é a forma atóxica da amônia, gerada pelo catabolismo de aminoácidos no fígado e pela microflora intestinal, sendo excretada pelos rins via filtração glomerular. Em bezerros, o teor de uréia no sangue tende a ser baixo, pois observa-se intenso anabolismo em sua curva de crescimento. A produção de uréia é influenciada pela baixa perfusão renal, degradação tissular, desequilíbrios hidro-eletrolíticos por hipovolemia associada a hemorragia ou desidratação e enfermidades hepáticas (COELHO, 2002). 
A avaliação hematológica neonatal representa um recurso diagnóstico de grande valia, pois a incidência de anemia em diferentes graus é relativamente alta em bezerros da raça Holandesa (LISBÔA, 2000). Mohri et al. (2007) afirmam haver relação entre a disponibilidade de ferro para os neonatos e a concentração de hemoglobina e o hematócrito. A hemoglobina fetal tende a desaparecer e ser substituída pela adulta logo ao nascimento. Os eritrócitos adultos são de menor tamanho e necessitam de menores quantidades de hemoglobina, sem necessariamente relacionar-se aos níveis sangüíneos de ferro. Adams et al. (1993) verificaram redução do número de hemácias em neonatos nascidos em distocia, contribuindo para maior taxa de morbidade/mortalidade. Contudo, o eritrograma não se altera conforme a higidez ou a disfunção respiratória em bezerros (BENESI, 1992).

\subsection{Conseqüências maternas}

\subsubsection{Ocitocina}

As primeiras contrações uterinas durante o pródromos do parto são irregulares e pouco intensas, posteriormente, tornam-se rítmicas e enérgicas. Considera-se que o número de contrações inferior a 4 por período denotam deficiência de contratilidade uterina, podendo alterar a evolução normal do parto (LANDIM-ALVARENGA, 2006).

A inércia uterina ocorre quando as contrações miometriais são insuficientes para expulsão fetal, mesmo com a cérvice totalmente dilatada. Em rebanhos leiteiros, corresponde a $10 \%$ dos casos de distocia em pluríparas. Em novilhas com sobre-peso, a inércia uterina ocorre por redução na disponibilidade de magnésio e cálcio, levando ao prolongamento do segundo estágio do parto (MEE, 2008). A inércia uterina primária tem como causas a deficiência de cálcio, magnésio e selênio (miodegeneração), senescência, debilidade, falta de exercícios e prematuridade. A inércia uterina pode ser secundária à exaustão pelo prolongamento do segundo estágio, alterações na estática fetal e gemelaridade (NOAKES et al., 2001). 
Usualmente, as deficiências de contração uterina na espécie bovina não são conduzidas com o uso de agentes ecbólicos. Entretanto, sabe-se que a extração fetal com força intensa pode causar sérios danos como fraturas e luxações nos bezerros e paralisia de nervos maternos (RICE, 1994). Portanto, para a indução de contrações uterinas, a administração de ocitocina pode ser preconizada. Taverne et al. (2001) afirmam que o miométrio de vacas prenhes é responsivo a doses exógenas de ocitocina, com maior atividade miometrial após a luteólise pré-parto. Contudo, pouco se sabe acerca da ação direta ou indireta deste hormônio sobre o feto. A administração de ocitocina como auxiliar ao parto é rotineira em eqüinos, mas são relatados efeitos adversos aos potros neonatos (MACPHERSON et al., 1997).

A ocitocina é um hormônio neuropeptídico sintetizado em diversos sítios do hipotálamo (supra-ótico e paraventricular), sendo estocada e liberada pela neurohipófise. Possui uma série de ações fisiológicas, entre elas: contração uterina, reflexo da ejeção do leite e indução do comportamento sexual e maternal. Sabe-se, ainda, que a ocitocina influencia a excreção renal de eletrólitos com aumento na taxa de filtração glomerular e natriurese e expressa receptores em vários tecidos como os rins, hipófise, glândula mamária, cérebro, vasos e coração (GUTKOWSKA et al., 2000). Mukaddam-Daher et al. (2001) demonstraram que a ocitocina participa também de regulações endócrinas e neuroendócrinas de órgãos como o coração, com efeito parassimpático inotrópico e cronotrópico negativo. A liberação de acetilcolina age em receptores muscarínicos, diminuindo a freqüência e força de contração do coração. A atividade cardíaca da ocitocina manifesta-se pela presença de receptores no átrio direito e na parede dos vasos, promovendo alterações da pressão arterial (hipotensão), acompanhadas de bradicardia e diminuição do rendimento cardíaco. Segundo Gutkowska et al. (2000), a ocitocina também pode ser sintetizada no coração e em grandes vasos. Com base em tais informações, sugere-se que os partos induzidos com a administração da ocitocina exógena podem levar ao comprometimento fetal pela hipotensão e bradicardia materna.

A ocitocina durante o parto pode funcionar como um fator agravante do estresse, pois verificou-se aumento dos níveis circulantes de ACTH em mulheres com partos induzidos por tal hormônio (OCHEDALSKI et al., 2001). De fato, infusões parenterais de ocitocina nos quadros de distocia materna em mulheres acarretam bradicardia fetal, por diminuição do fluxo sangüíneo uterino e hipotensão materna (CABBAD et al., 1985). Desta forma, acredita-se que este hormônio possa 
intensificar o estresse durante o parto e agir diretamente sob a circulação placentária e fetal.

Durante períodos de estresse ou durante o parto, é de extrema importância haver homeostase nos níveis circulantes de glicose. Além dos clássicos efeitos da ocitocina, há evidências da importante atuação no acréscimo plasmático de glucagon, insulina e glicose em cães adultos (WALLIN et al., 1989). Ainda, em ovelhas, observou-se que a hipóxia crônica acarreta reduzida resposta do miometro à ocitocina, por diminuição do número de receptores miometriais (DUCSAY, 1998). As endorfinas liberadas durante a algesia e o estresse do parto possuem papel inibidor do efeito ecbólico da ocitocina no útero. O estímulo contrátil com doses exógenas excessivas de ocitocina também pode levar ao espasmo uterino (GILBERT et al., 1992).

\subsubsection{Efeitos Hemodinâmicos}

As alterações hemodinâmicas decorrentes da ação dos hormônios sexuais e glicocorticóides durante a gestação em mulheres priorizam o aumento de volume sangüíneo e débito cardíaco, além da redistribuição do fluxo sangüíneo para útero, rins, mucosas nasais e mamas (HORWITZ; HORWITZ, 1982). Em mulheres, o débito cardíaco pode aumentar $20 \%$ no período que precede o trabalho de parto (PONTES JR.; ANDRADE, 2000). Em ovelhas, tal acréscimo pode alcançar $30 \%$ e está associado ao aumento do volume sangüíneo circulante e da freqüência cardíaca (LANDIM-ALVARENGA, 2006). Embora ocorram mudanças hemodinâmicas significativas de origem anatômica, hormonal e metabólica, observase ainda a diminuição resistência vascular periférica (PONTES JR.; ANDRADE, 2000).

A força exercida pelo sangue nas paredes arteriais durante a sístole cardíaca corresponde à pressão arterial sistólica. A pressão arterial diastólica é o reflexo da contração vascular anterior, durante o relaxamento do músculo cardíaco (HAMLIN, 1988). A pressão arterial média é influenciada pela freqüência cardíaca e resistência vascular sistêmica. Para predizer os efeitos cardiovasculares sistêmicos, a pressão de pulso é um potente indicador, pois fornece o índice de rigidez da parede arterial, 
além de indiretamente relacionar-se à contração cardíaca, rigidez das grandes artérias e à própria freqüência do coração (SOUSA et al., 2004).

O controle hormonal e nervoso da pressão e volume sangüíneo ocorre principalmente por meio de dois reflexos: os barorreceptores arteriais e do receptor de volume atrial. A queda na pressão arterial sistêmica sensibiliza os barorreceptores e, por estimulação simpática e inibição parassimpática, há vasoconstrição reflexa, aumento da contratilidade e freqüência cardíacas e conseqüente aumento da resistência vascular periférica e débito cardíaco. Ainda, a redução do volume sangüíneo estimula o sistema renina-angiotensina-aldosterona e o hormônio anti-diurético (ADH) para diminuir a excreção renal de sódio e aumentar a reabsorção de água (STEPHENSON, 2004).

Além da ação do sistema nervoso simpático, alguns hormônios participam da homeostasia do sistema circulatório, tais como a vasopressina, a angiotensina-Il e os glicocorticóides. No entanto, pouco se sabe acerca da atuação hormonal nos barorreceptores durante a gestação e trabalho de parto nos animais domésticos. Segundo Brooks et al. (1994), a diminuição do reflexo hipertensor em cadelas gestantes e a menor habilidade em manter a pressão arterial ocorre por insuficiência dos hormônios reguladores da homeostasia. A dor aguda causada pelo parto promove alterações cardio-circulatórias, tais como hipertensão e taquicardia. Simultâneamente, a analgesia endógena compensatória é modulada por $\beta$ endorfinas hipofisárias, bem como a liberação do hormônio adrenocorticotrófico (ACTH) (MOORE, 2006).

A mensuração da freqüência cardíaca pode ser utilizada como indicador de estresse em bovinos, por apresentar mudanças rápidas e de fácil detecção. No entanto, é preciso cautela quanto à promoção de estresse de contenção. O aumento das concentrações sangüíneas de catecolaminas pode ser empregado alternativamente como marcador de situações de estresse, mas é um reflexo considerado lento e progressivo (LEFCOURT et al., 1999).

O eletrocardiograma (ECG) é um recurso cardiológico que permite a detecção, em diferentes níveis, do processo de despolarização cardíaca e do ritmo cardíaco. Os eletrodos posicionados na superfície corpórea são capazes de detectar o campo elétrico ao redor do coração durante a despolarização e repolarização. A excitação elétrica normal no coração, por meio de vias especializadas de condução 
intra-cardíacas, são essenciais para coordenar a contração e o relaxamento do miocárdio. O controle deste mecanismo homeostático altera a freqüência cardíaca no intuito de manter o débito cardíaco apropriado, possivelmente afetando o ritmo do coração (PATTESON, 1999).

Nenhum sistema de derivações eletrocardiográficas é universalmente aceito para uso em grandes animais. Em bovinos, o sistema de Purkinje cardíaco penetra profundamente e a despolarização ventricular ocorre explosivamente em muitas direções (DEROTH, 1980). Tais particularidades contribuem para a inaparência da formação de ondas ou complexos no eletrocardiograma. Por esta razão, o EGC é principalmente usado, em grandes animais, para o acompanhamento do ritmo cardíaco e a detecção de possíveis arritmias (REEF; MCGUIRK, 2006).

\subsection{Glicemia e Cortisol}

A glicemia das fêmeas bovinas sofre influência de diversos fatores de variação como idade, raça, níveis de energia na dieta, produção de leite e fatores climáticos como umidade e temperatura ambiental. O estresse térmico eleva a freqüência respiratória e requer rápida mobilização de glicose sangüínea pelos músculos respiratórios e conseqüente queda da glicemia (POGLIANI, 2006). De acordo com Fagliari et al. (1998), há redução dos teores plasmáticos de glicose no puerpério de vacas Holandesas, atribuída ao balanço energético negativo e à alta demanda de glicose para a lactação. Portanto, os níveis energéticos e a quantidade de precursores gliconeogênicos na dieta oferecida devem ser adequados para a produção de glicose neste período (MARQUES JUNIOR et al., 1996). Por outro lado, segundo Diesch et al. (2004), o escore de condição corporal materno no momento do parto não influencia a higidez neonatal.

Durante a gestação, os carboidratos provenientes da circulação materna são estocados nos tecidos fetais na dependência da atividade adrenal. Por exemplo, a produção de ACTH ou corticosteróides fetais eleva o estoque de glicogênio hepático (LANDIM-ALVARENGA, 2006). Os teores de glicose em bezerros logo ao nascimento, na ausência da ingestão de colostro, estão relacionados ao metabolismo hepático e de glicogênio muscular, os quais respondem principalmente 
à ação de catecolaminas, como a noradrenalina e adrenalina (CHAN et al., 1993).

Os neonatos de baixo peso ou submetidos à hipoxemia durante a distocia, sepsis ou toxemia são predispostos à hipoglicemia. Nestes casos, são evidenciados sinais clínicos como incoordenação motora, flacidez, fraqueza e coma (MOON et al., 2001). A maioria dos neonatos debilitados também são hipoglicêmicos, principalmente por ocorrer depleção dos estoques de glicogênio e, ainda, imaturidade hepática (MACINTIRE, 1999). Salhab et al. (2004) observaram que a hipoglicemia é um fator de risco adicional à injúria cerebral, principalmente em neonatos deprimidos por hipóxia, isquemia e asfixia ou submetidos a manobras de ressuscitação.

O estresse climático extremo consome drasticamente as reservas energéticas para a produção de calor por bezerros ao nascimento, acarretando em hipoglicemia mais intensa. Neste contexto, a hipoglicemia cerebral pode ocorrer por distribuição de reservas de glicose para os tecidos periféricos (VAALA et al., 2006). A tolerância relativa dos recém-nascidos à hipóxia também é atribuída às concentrações de glicogênio no músculo cardíaco. A manutenção dos batimentos cardíacos em situações de hipóxia ocorre por glicólise anaeróbica reflexa. No entanto, o cérebro não possui reservas de glicogênio e necessita dos teores circulantes de glicose (LANDIM-ALVARENGA, 2006).

Os bezerros nascidos sob auxílio obstétrico apresentaram glicemia aos 30 minutos do parto maior do que aqueles provenientes de cesariana ou parto normal (BELLOWS; LAMMOGLIA, 2000). Segundo Massip (1980), o aumento transitório da glicose sangüínea neste momento ocorre por aumento da glicogenólise hepática direta. Tal processo ocorre como resposta ao estresse do parto e do ambiente extrauterino, denominado hiperglicemia de estresse.

Certas condições ambientais e de manejo (transporte, parto, desmama, vacinação, entre outros) ativam o eixo hipotalâmico-pituitário-adrenal e o eixo simpático-adrenal para a liberação de cortisol, sendo portanto considerados fatores de estresse. Muitos estudos também relacionam os níveis circulantes de cortisol a ações negativas sobre o sistema imune (MUNIZ, 2001). Em bovinos, durante o estresse do trabalho de parto e a passagem do feto pelo canal vaginal, os níveis de glicocorticóides maternos elevam-se significativamente, pois também são essenciais para o estabelecimento da lactogênese (LANDIM-ALVARENGA, 2006). A incidência 
de distocia também está associada à condição de estresse antes e durante o parto. $\mathrm{O}$ aumento do cortisol circulante e a duração do parto são riscos potenciais para a ocorrência de distocia e natimortalidade (BURTON et al., 2006).

O cortisol é um hormônio corticosteróide produzido pelo córtex das glândulas adrenais, estimulado pelo hormônio adrenocorticotrófico (ACTH) da adeno-hipófise. Este, por sua vez, é regulado pelo hormônio liberador de corticotropina (CRH), produzido no núcleo paraventricular do hipotálamo. Em geral, as concentrações de glicocorticóides diminuem no início da gestação e permanecem baixas por longo período. Entretanto, durante o parto, na maioria das espécies, suas concentrações atingem o nível máximo (MUNIZ, 2001). O cortisol pode atravessar a barreira placentária apenas quando em níveis elevados e em situações extremas de estresse. Porém, o perfil de glicocorticóides em bezerros não deve ser estabelecido sem que se considere as concentrações maternas, por ocorrer aumento significativo no periparto (HUNTER et al., 1977). Os níveis plasmáticos de cortisol fetal aumentam 7 dias antes do parto (aproximadamente $20 \mathrm{ng} / \mathrm{mL}$ ), seguidos por rápida e significativa elevação $(50 \mathrm{ng} / \mathrm{mL}) 3$ horas antes do nascimento, atingindo valores extremos (100 ng/mL) imediatamente após o parto (HUNTER et al., 1977).

O período neonatal é um desafio aos recém-nascidos e a sobrevivência depende da capacidade de adaptação ao estresse de múltiplas origens imposto pelo ambiente extra-uterino. O recém-nascido deve estar apto a assumir quase que instantaneamente as funções vitais antes exercidas pela placenta. O sistema endócrino é um dos principais participantes deste processo de homeostase orgânica, frente aos novos confrontos vivenciados (BENESI, 1992).

O início da função ou maturação hipotalâmica fetal ocorre por estímulos no desenvolvimento de sinapses no núcleo paraventricular, permitindo evolução da função neuroendócrina. Desta forma, o hipotálamo fetal passa a responder aos efeitos de hormônios placentários como estrógeno, progesterona, prostaglandina $\mathrm{E} \mathrm{e}$ dos fatores de liberação de corticotrofinas. Ademais, fatores estressantes como a hipóxia, mudanças na pressão sangüínea e disponibilidade de glicose podem levar ao aumento na secreção de cortisol pela adrenal do feto (LANDIM-ALVARENGA, 2006). Tal eixo endócrino é ativado aproximadamente 2 semanas antes do parto, porém o aumento significativo do cortisol fetal ocorre 2 a 3 dias antes do nascimento (RICE, 1994). Além da resposta reflexa ao estresse, a produção de cortisol exerce importante função na maturação de órgãos fetais (pulmões, fígado, pâncreas e pele) 
e no disparo do mecanismo de parto (DUCSAY, 1998). O cortisol fetal atua na placenta diminuindo a concentração local de progesterona e aumentando a secreção de estrogênio, mecanismo que promove a síntese e liberação de prostaglandina F2 $\alpha$ (PGF2 $\alpha$ ) e estímulo das contrações uterinas (SWENSON; REECE, 1996; PINEDA, 2003).

A capacidade do feto em inibir o eixo hipotálamo-hipófise-adrenal é tão importante quanto sua ativação, pois a manutenção de elevados níveis de glicocorticóides por longos períodos pode promover efeitos deletérios (DUCSAY, 1998). A elevação de glicocorticóides durante a gestação induz a efeitos catabólicos como lipólise, glicogenólise e catabolismo protéico, resultando em aumento dos níveis séricos de glicose (MUNCK et al., 1984). O pico de cortisol, na circulação fetal, ocorre alguns dias antes do parto e declina apenas 7 a 10 dias após 0 nascimento (LANDIM-ALVARENGA, 2006).

Hoyer et al. (1990) observaram elevação da concentração plasmática de glicocorticóides em neonatos bovinos nos primeiros seis dias de vida, em especial os que sofreram asfixia no período perinatal. O referido perfil hormonal pode ser interpretado como resposta do neonato ao novo ambiente extra-uterino e a reduzida capacidade de metabolização hormonal do bezerro. Em casos de distocia grave, sabe-se que a sobrevivência neonatal é menor, pois o aumento da força de tração fetal eleva os níveis de cortisol plasmático. 
Materiais e Métodos 


\section{MATERIAIS E MÉTODOS}

As condições de utilização dos animais neste experimento estavam em concordância com as normas éticas, segundo julgamento da Comissão de Bioética da Faculdade de Medicina Veterinária e Zootecnia da Universidade de São Paulo.

\subsection{Animais e grupos experimentais}

O presente estudo foi realizado durante o período de julho de 2007 a fevereiro de 2008 na Fazenda Santa Rita - Agrindus S/A, localizada no município de Descalvado (SP). Trata-se de uma propriedade produtora de leite tipo A, com matrizes bovinas da raça Holandesa de alta produção. No período compreendido entre janeiro e agosto de 2007, a fazenda apresentou os seguintes índices zootécnicos: 1003 partos, 8,6\% de natimortalidade, 6\% de abortamento, 22\% de retenção placentária e $39 \%$ de distocia (representada principalmente pela categoria das fêmeas primíparas). A temperatura e umidade ambientais médias na região da fazenda durante o período experimental foram de 17,6 a $23,5^{\circ} \mathrm{C}$ e 68,3 a $79,7 \%$, respectivamente (PCAPS-USP).

Foram utilizados 30 neonatos e 30 fêmeas bovinas da raça Holandesa, primíparas e pluríparas, clinicamente sadias, sem histórico de alterações reprodutivas (ciclicidade) e anatômicas. Os animais pertenciam a lotes controlados sanitária e nutricionalmente, evitando-se afecções metabólicas e epidemias enzoóticas.

A partir do início do período seco (não-lactantes), as fêmeas gestantes permaneceram em um piquete maternidade, no qual recebiam concentrado a base de minerais, farelo de soja ( $46 \%$ de proteína bruta), poupa cítrica, silagem de milho ( $34 \%$ de matéria seca) e tifton ( $23 \%$ de matéria seca) três vezes ao dia. Com a proximidade da data estimada para o parto (277 dias a partir da última IA), as fêmeas foram monitorizadas diariamente e de acordo, principalmente, com aumento de volume do úbere, eram transferidas à maternidade. Neste local, as vacas permaneceram em 10 baias individuais com forração de areia e cobertura superior 
(Figura 1) e recebiam a mesma alimentação descrita anteriormente. Após o parto, os bezerros foram retirados das mães e transferidos a galpões semi-abertos com baias individuais (fêmeas) ou coletivas (machos) forradas com feno.

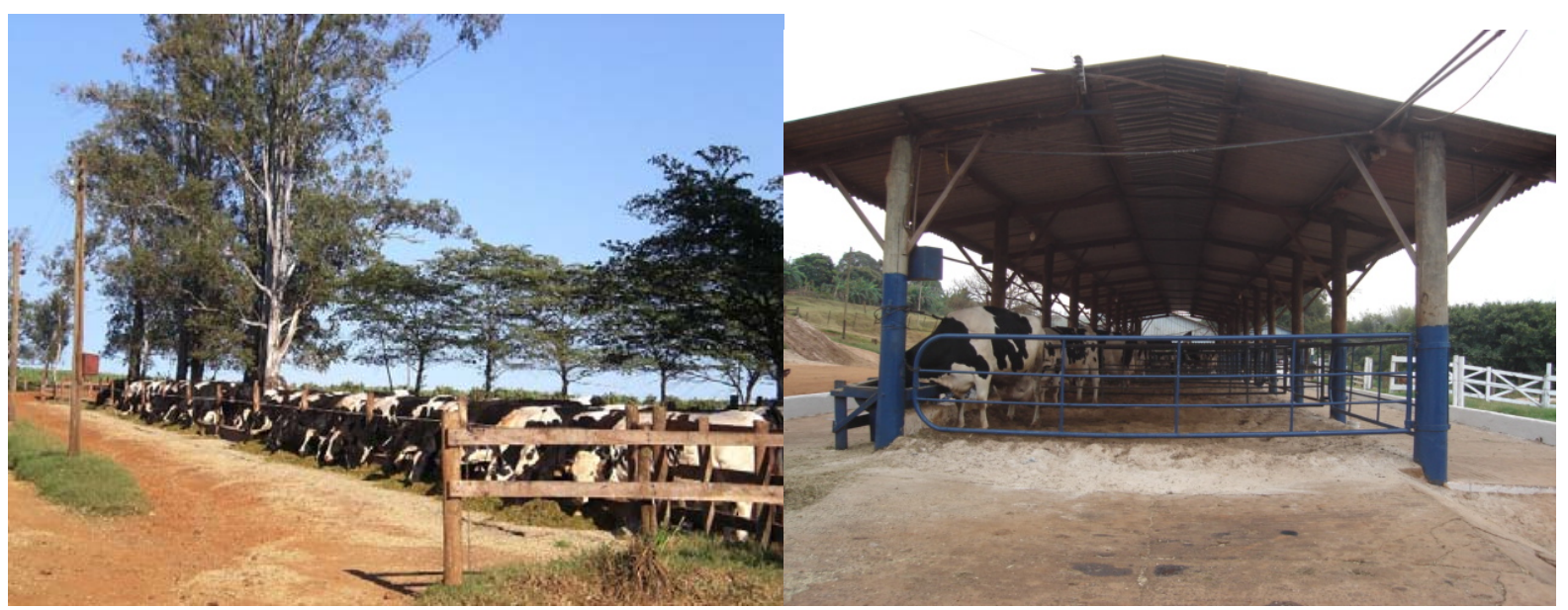

Figura 1 - Fêmeas gestantes no piquete maternidade e nas baias de parição da Fazenda Santa Rita - Agrindus S/A - São Paulo - 2008.

Os grupos experimentais foram determinados segundo a condição obstétrica das fêmeas bovinas:

GRUPO EUT (G EUT): eutocia, considerada como o parto sem assistência externa ou com leve auxílio manual e duração da fase expulsiva inferior a 2 horas Este grupo foi composto por 5 primíparas e 5 pluríparas $(n=10)$ e por 6 bezerros machos e 4 fêmeas $(n=10)$.

GRUPO DIST (G DIST): distocia para a qual foi necessária intervenção obstétrica por meio da extração fetal forçada moderada a intensa e duração da fase expulsiva superior a 2 horas. Constituiu-se de 10 fêmeas primíparas $(n=10)$ e de 7 bezerros machos e 3 fêmeas $(n=10)$.

GRUPO OCT (G OCT): distocia por inércia uterina para a qual foi instituído o protocolo de indução de contrações uterinas com ocitocina e duração da fase expulsiva superior a 2 horas. Este grupo foi composto por 9 fêmeas pluríparas e 1 primípara $(n=10)$ e por 6 bezerros machos e 4 fêmeas $(n=10)$.

O parto foi assistido desde sua fase prodrômica até a expulsão completa dos envoltórios fetais. O diagnóstico de distocia foi estabelecido com base na duração da 
fase expulsiva, iniciada a partir da ruptura das membranas fetais. Ainda, a classificação da distocia e a definição diagnóstica foram determinadas pelo exame obstétrico externo e interno. Por meio da palpação vaginal, avaliou-se a via fetal mole e óssea, considerando a estática fetal e disposições anatômicas da fêmea. Para as fêmeas do Grupo DIST, a distocia decorreu principalmente de incompatibilidade de diâmetros por causa fetal (dimensões do feto) ou materna (estreitamento pélvico). A assistência ao parto no Grupo DIST foi realizada com o auxílio de correntes obstétricas, após prévia higienização e assepsia, e consistiu da extração forçada fetal de grau moderado a intenso, para a qual foi necessária a força de tração executada por no máximo dois ou três indivíduos, respectivamente.

No Grupo OCT, foram consideradas apenas as fêmeas com diagnóstico de atonia ou hipotonia uterina, distocia materna caracterizada também por prolongamento da fase expulsiva (superior a 2 horas), porém de progresso fetal no conduto pélvico lento ou ausente associado à ausência de contrações abdominais evidentes e relaxamento uterino. A terapia foi instituída com a infusão lenta de $50 \mathrm{UI}$ de ocitocina (Orastina ${ }^{\circledR}$ ) e $11,62 \mathrm{~g}$ de gluconato de cálcio (Glucafós ${ }^{\circledR}$ ), diluídos em $100 \mathrm{~mL}$ de solução fisiológica a 0,9\%. Os animais foram mantidos em estação após contenção e a veia jugular ou mamária cateterizada (cateter Intracath 22G) para a infusão lenta da solução (em aproximadamente 30 minutos). Após a terapia ecbólica, as fêmeas foram liberadas e a evolução do parto, assistida. Para as fêmeas do G OCT, nenhuma ou leve assistência médica foi realizada para a expulsão fetal.

\subsection{Delineamento experimental}

A determinação das variáveis maternas e neonatais seguiu um padrão de repetições ao longo do tempo, em períodos previamente definidos. As análises experimentais, bem como os respectivos momentos nos quais foram realizadas estão sumariadas no quadro 1. 


\begin{tabular}{|l|c|}
\hline \multicolumn{1}{|c|}{ Procedimento } & Período \\
\hline \multicolumn{2}{|c|}{ MÃE } \\
\hline Pressão arterial não-invasiva & Pré-parto \\
Freqüência cardíaca (auscultação torácica) & Intra-parto \\
Eletrocardiograma & Pós-parto \\
Dosagem de cortisol & 1h pós-parto \\
Glicemia & NEONATO \\
\hline & Ao nascimento e 60 minutos \\
\hline Hemogasometria arterial & \\
Glicemia & Ao nascimento, 5 e 60 minutos \\
Dosagem de cortisol & \\
\hline Temperatura corpórea & \\
Escore Apgar & \\
\hline
\end{tabular}

Quadro 1 - Procedimentos maternos e neonatais e seus respectivos momentos de execução - São Paulo - 2008

Como critério de execução das avaliações maternas, os seguintes momentos foram adotados:

- Pré-parto: período das 48 horas anteriores à ruptura dos envoltórios fetais, considerado também como a fase preparatória do parto ou pródomos, de acordo com sinais clínicos evidentes de desconforto abdominal, elevação da cauda, reflexos constantes de micção e defecação e eliminação de muco vaginal.

- Intra-parto (IP): após a ruptura da membrana alantoidiana até a expulsão fetal completa. As avaliações maternas foram realizadas em momento pontual e aleatório deste período, simultaneamente às contrações abdominais quando possível.

- Pós-parto (PP): até aproximadamente 20 minutos após a expulsão fetal.

- Uma hora pós-parto (1hPP): decorrida 1 hora da avaliação anterior (pós-parto).

Para estabelecer os momentos das avaliações neonatais, os seguintes critérios foram adotados:

- Ao nascimento (0’): até, no máximo, 15 minutos após a expulsão do bezerro. 
- Aos cinco minutos (5'): após 5 minutos da avaliação anterior (ao nascimento).

- Aos sessenta minutos (60'): decorridos 60 minutos da avaliação ao nascimento.

\subsection{Avaliação materna}

Com vistas a identificar alterações hemodinâmicas durante a eutocia, distocia e administração de ocitocina, foram realizados controle da pressão arterial e monitoramento cardíaco. As fêmeas bovinas foram contidas na própria baia de parição e permaneciam em estação, exceto no período intra-parto, momento no qual algumas vacas encontravam-se em decúbito esternal. Optou-se por não alterar drasticamente o posicionamento das vacas durante o parto, a fim de evitar eventuais interferências do estresse de manipulação sobre as variáveis estudadas.

Os procedimentos maternos consistiram da auscultação torácica para medida da freqüência cardíaca (FC), mensuração da pressão arterial não invasiva (PA) e controle eletrocardiográfico (ECG), as duas últimas avaliações realizadas com auxílio de Monitor Modular Multiparamétrico Dixtal® Modelo DX-2021 (Figura 2). A PA foi mensurada através de um manguito inflável aplicado confortavelmente à base da cauda do animal, em topografia da artéria coccígea ventral. Os resultados da PA foram calculados pela média de 3 mensurações sucessivas, as quais constavam as pressões sistólica, diastólica e média.

Para o acompanhamento eletrocardiográfico, foram fixados eletrodos diretamente na pele do animal de acordo com a derivação II ou basoapical na velocidade de $25 \mathrm{~mm} / \mathrm{s}$. Os eletrodos foram umedecidos com álcool etílico hidratado $92,8 \%$ para melhor propagação do sinal elétrico. Os traçados eletrocardiográficos foram fotografados digitalmente para posterior descrição do ritmo cardíaco.

Para a determinação do cortisol sérico e glicemia, aproximadamente $5 \mathrm{~mL}$ de sangue total foi colhido através da veia coccígea ou mamária e destinados a tubos sem anticoagulante, com gel, estéril ou diretamente ao glicosímetro (Monitor Advantage - Roche®). Para a obtenção das amostras de soro, os tubos com sangue foram imediatamente centrifugados no local da colheita a 1500 xg por 10 minutos. $O$ 
soro assim obtido foi aliquotado em microtubos plásticos e acondicionado em freezer a $-20^{\circ} \mathrm{C}$ até o processamento.

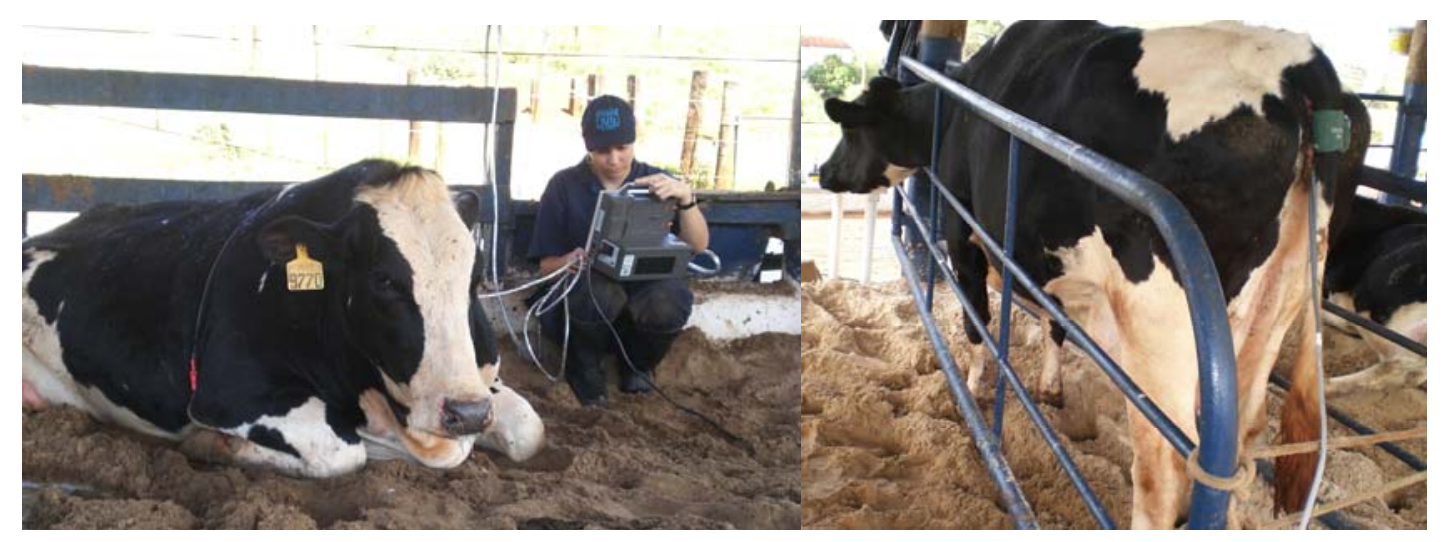

Figura 2 - Avaliação eletrocardiográfica e mensuração da PA em fêmeas Holandesas no periparto - São Paulo - 2008

\subsection{Avaliação neonatal}

A vitalidade neonatal foi verificada por meio do sistema Apgar (Figura 3), a partir do qual foram avaliadas, por auscultação torácica, a freqüência e ritmo cardíacos (1) e a freqüência e esforço respiratórios (2). Ainda, foi determinado o grau de tonicidade muscular (3) do neonato, por observação principalmente da capacidade de manter-se em decúbito esternal e movimentos de cabeça. A irritabilidade reflexa (4) foi estimada por responsividade do neonato à manipulação durante o exame. E, por fim, a coloração das mucosas (5) ocular e gengival foi inspecionada, verificando-se a presença de palidez ou cianose. Cada uma das 5 variáveis descritas foi pontuada com notas de 0,1 ou 2 e a somatória final do escore (0-10), considerada a medida de vitalidade (Quadro 2). Em períodos equivalentes à determinação do escore Apgar, a temperatura retal dos neonatos foi aferida (Figura 3). 


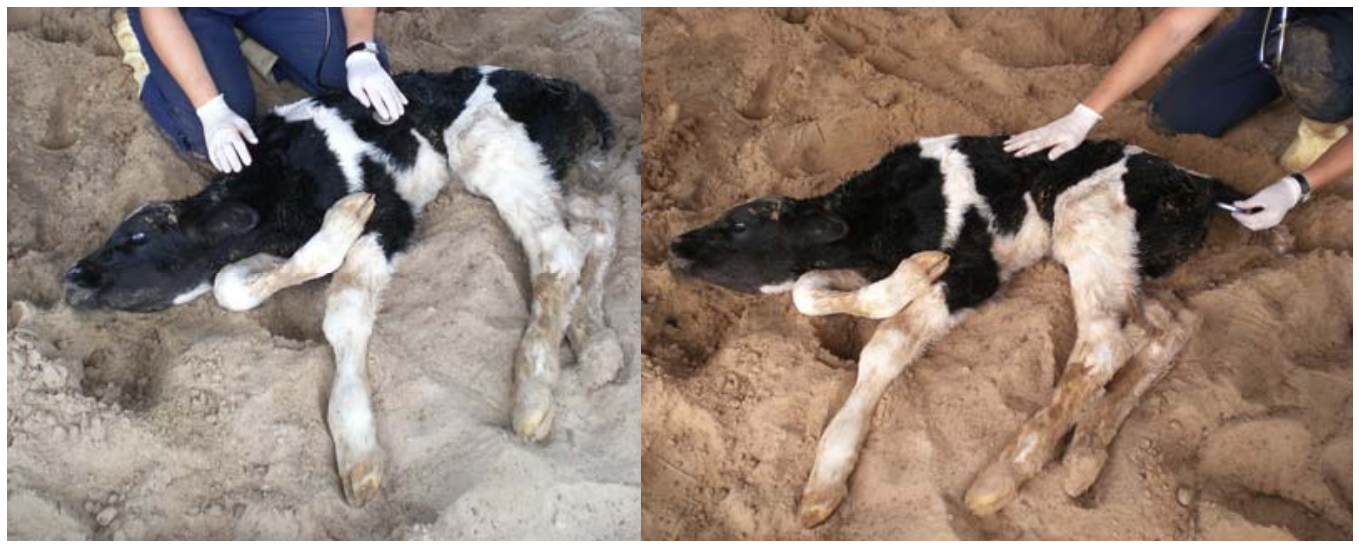

Figura 3 - Avaliação do escore Apgar de vitalidade neonatal e da temperatura corpórea de bezerros Holandeses ao nascimento - São Paulo - 2008

\begin{tabular}{|l|ccc|}
\hline \multicolumn{1}{|c|}{ Variáveis } & \multicolumn{3}{c|}{ Valores } \\
\hline & $\mathbf{0}$ & $\mathbf{1}$ & $\mathbf{2}$ \\
\hline Freqüência cardíaca & Ausente & Bradicardia / Irregular & Normal / Regular \\
\hline Esforço respiratório & Ausente & Irregular & Regular \\
\hline Tônus muscular & Flacidez & Alguma flexão & Flexão \\
\hline Irritabilidade reflexa & Ausente & Algum movimento & Hiperatividade \\
\hline $\begin{array}{l}\text { Coloração de } \\
\text { mucosas }\end{array}$ & Cianóticas & Hipocoradas & Normocoradas \\
\hline
\end{tabular}

Quadro 2 - Escore Apgar para avaliação de vitalidade neonatal. Fonte: Oliveira (1999), modificada - São Paulo - 2008

Dos neonatos, $3 \mathrm{~mL}$ de sangue foi colhido por punção da veia jugular para determinação do cortisol sérico e processado de maneira semelhante a descrita para a avaliação materna. Para análise hemogasométrica, bioquímica e hematológica dos bezerros, $1 \mathrm{~mL}$ de sangue arterial foi colhido por punção da artéria femural ou coccígea em seringas de $3 \mathrm{~mL}$ previamente heparinizadas e imediatamente depositado no analisador clínico portátil i-STAT (Abbott®). A partir das amostras de sangue arterial foram determinados: $\mathrm{pH}, \mathrm{pO}_{2}$ (pressão de oxigênio - mmHg), $\mathrm{pCO}_{2}$ (pressão de dióxido de carbono - $\mathrm{mmHg}$ ), $\mathrm{TCO}_{2}$ (dióxido de carbono total - $\mathrm{mmol} / \mathrm{L}$ ), $\mathrm{HCO}_{3}{ }^{-}$(bicarbonato - mmol/L), BE (base excess - mmol/L), anion gap ( $\left.\mathrm{mmol} / \mathrm{L}\right)$ e $\mathrm{SO}_{2}$ (saturação de oxigênio - \%), glicemia ( $\mathrm{mg} / \mathrm{dL}$ ), concentração de hemoglobina 
$(\mathrm{g} / \mathrm{L})$, hematócrito $(\%)$, uréia nitrogenada $\left(\mathrm{mg} / \mathrm{dL}\right.$ ) e os íons $\mathrm{Na}^{+}$(sódio $-\mathrm{mmol} / \mathrm{L}$ ), $\mathrm{Cl}^{-}$ (cloro - $\mathrm{mmol} / \mathrm{L}$ ) e $\mathrm{K}^{+}$(potássio - $\mathrm{mmol} / \mathrm{L}$ ). Os valores foram corrigidos de acordo com a temperatura corpórea do animal (Figura 4).

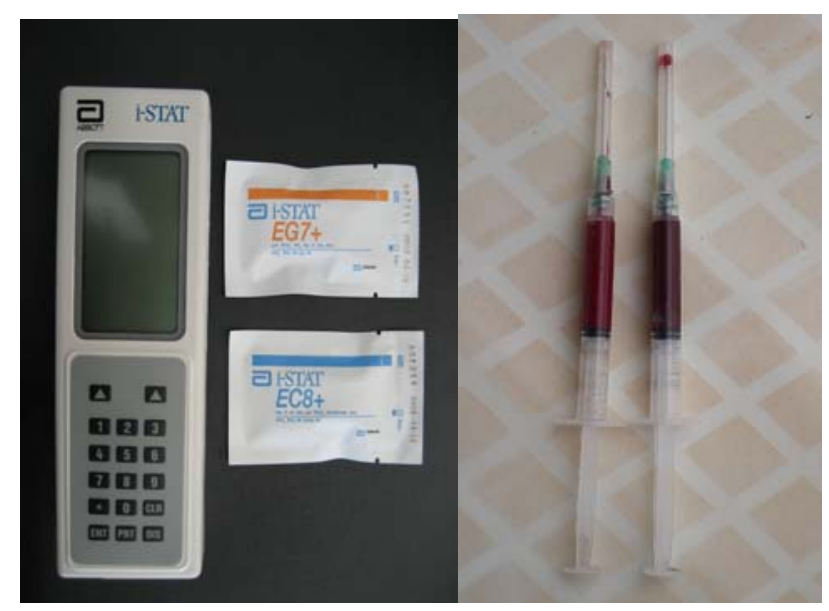

Figura 4 - Analisador clínico portátil i-STAT (Abbott $囚)$, cartuchos e seringas de $3 \mathrm{~mL}$ com respectivos sangues arterial e venoso de bezerros neonatos - São Paulo - 2008

\subsection{Dosagem de cortisol}

A dosagem do cortisol sérico foi realizada no Laboratório de Dosagens Hormonais do Departamento de Reprodução Animal da Faculdade de Medicina Veterinária e Zootecnia da USP. A partir do soro, foram determinadas as concentrações de cortisol, utilizando-se técnica comercial de radioimunoensaio (RIE), por método de quantificação em fase sólida, com base na competição do cortisol com o hormônio marcado com radioatividade. O kit comercial de cortisol empregado foi o Cortisol Coat-A-Count (DPC®) e os valores expressos em $\mu \mathrm{g} / \mathrm{dL}$, após conversão, com auxílio da curva de calibração preparada conjuntamente. Posteriormente, os dados foram convertidos para a unidade $\mathrm{ng} / \mathrm{mL}$. Para o controle de qualidade do RIE foram aferidos os coeficientes intra-ensaio, inter-ensaio e a sensibilidade mínima detectada (Tabelas 1 e 2). 
Tabela 1 - Controle de qualidade do radioimunoensaio para dosagem de cortisol coeficiente de variação inter-ensaio - São Paulo - 2008

\begin{tabular}{|c|c|c|c|c|c|c|c|c|c|}
\hline & \multicolumn{4}{|c|}{ Controle } & \multirow{2}{*}{$\begin{array}{c}\text { CPM } \\
\text { ponto } \\
0\end{array}$} & \multirow{2}{*}{$\begin{array}{l}\text { CPM } \\
\text { total }\end{array}$} & \multirow{2}{*}{$\begin{array}{c}\text { Cap } \\
\text { Lig. } \\
\text { B/B0 }\end{array}$} & \multirow{2}{*}{$\begin{array}{c}\text { L.N.E. } \\
\text { CPM }\end{array}$} & \multirow{2}{*}{$\begin{array}{r}\text { L.N.E. } \\
(\%)\end{array}$} \\
\hline Ensaio & C1 & $\mathrm{C} 2$ & C3 & C4 & & & & & \\
\hline 1 & 0,88 & 20,89 & 0,89 & 19,33 & 20776 & 35353 & $59 \%$ & 84,00 & 0,24 \\
\hline 2 & 1,74 & 23,98 & 1,79 & 23,70 & 20438 & 35169 & $58 \%$ & 89,00 & 0,25 \\
\hline \multicolumn{10}{|l|}{ CV } \\
\hline $\begin{array}{l}\text { Inter- } \\
\text { ensaio }\end{array}$ & 1,314 & 22,435 & 1,337 & 21,516 & & & & & \\
\hline
\end{tabular}

Tabela 2 - Controle de qualidade do radioimunoensaio para dosagem de cortisol coeficiente de variação intra-ensaio e sensibilidade. São Paulo, 2008.

\begin{tabular}{cccc}
\hline & $\begin{array}{c}\text { Sensibilidade } \\
\text { Ensaio }\end{array}$ & CV Intra & CV Intra \\
\hline $\mathbf{1}$ & $93(0,04)$ & Baixo & Alto \\
\hline $\mathbf{2}$ & $94(0,05)$ & $0,27 \%$ & $5,48 \%$ \\
CV Inter-ensaio & & $1,77 \%$ & $0,83 \%$ \\
\hline
\end{tabular}

\subsection{Valores de referência}

Os parâmetros utilizados como referência para as variáveis estudadas estão representados na tabela 3 (neonatais) e na tabela 4 (maternos). 
Tabela 3 - Valores de referência de bezerros ao nascimento - São Paulo - 2008

\begin{tabular}{|c|c|c|}
\hline Parâmetro (unidade) & Valor & Referência \\
\hline Temperatura corpórea $\left({ }^{\circ} \mathrm{C}\right)$ & $37-38$ & Vaala et al., 2006 \\
\hline Glicemia (mg/dL) & $65,00 \pm 21,66$ & Adams et al., 1993 \\
\hline Hemoglobina (g/dL) & $13,18 \pm 1,52$ & Benesi, 1992 \\
\hline Hematócrito (\%) & $40,67 \pm 4,29$ & Benesi , 1992 \\
\hline $\mathrm{pH}$ & $>7,20$ & Bleul et al., 2007 \\
\hline $\mathrm{pO}_{2}(\mathrm{mmHg})$ & $>70$ & Vaala et al., 2006 \\
\hline $\mathrm{pCO}_{2}(\mathrm{mmHg})$ & $<50$ & Vaala et al., 2006 \\
\hline $\mathrm{HCO}_{3}^{-}(\mathrm{mmol} / \mathrm{L})$ & $24,65-30,33$ & Bleul et al., 2007 \\
\hline $\mathrm{BE}(\mathrm{mmol} / \mathrm{L})$ & $(-) 1,41-5,07$ & Bleul et al., 2007 \\
\hline $\mathrm{TCO}_{2}(\mathrm{mmol} / \mathrm{L})$ & $18-36$ & Grupo Eutocia \\
\hline $\mathrm{SO}_{2}(\%)$ & $>50$ & Grupo Eutocia \\
\hline Anion-Gap & $6,81 \pm 3,78$ & Kaneto et al., 2004 \\
\hline BUN (mg/dL) & $2-14$ & Adams et al., 1993 \\
\hline $\mathrm{Na}^{+}(\mathrm{mmol} / \mathrm{L})$ & $130-148$ & Coelho, 2002 \\
\hline $\mathrm{K}^{+}(\mathrm{mmol} / \mathrm{L})$ & $4,3-6,1$ & Coelho, 2002 \\
\hline $\mathrm{Cl}^{-}(\mathrm{mmol} / \mathrm{L})$ & $93-107$ & Coelho, 2002 \\
\hline
\end{tabular}

Tabela 4 - Valores de referência maternos adotados - São Paulo - 2008

\begin{tabular}{lcc}
\hline \multicolumn{1}{c}{ Parâmetro (unidade) } & Valor & Referência \\
\hline $\begin{array}{l}\text { Pressão arterial diastólica - } \\
\text { sistólica }(\mathrm{mmHg})\end{array}$ & 50 a $85-100$ a 140 & \\
Cortisol $(\mathrm{ng} / \mathrm{mL})$ & $4,5-7,5$ & Radostits et al., 2002 \\
Glicemia $(\mathrm{mg} / \mathrm{dL})$ & $45-75$ & \\
Freqüência cardíaca $(\mathrm{bpm})$ & $50-85$ & \\
\hline
\end{tabular}




\subsection{Análise Estatística}

Os dados foram analisados por meio do programa Statistica ${ }^{\circ}$ 5. As variáveis foram submetidas às premissas estatísticas quanto à normalidade de distribuição dos resíduos pelo teste de Kolmogorov Smirnov. Logo, utilizou-se estatística paramétrica para tal procedimento.

Utilizou-se análise de variância para medidas repetidas no tempo (MANOVA), sendo os grupos obstétricos considerados como amostras independentes e as diversas variáveis maternas e neonatais e suas repetições, como amostras dependentes. Esta análise permitiu a comparação das diferentes variáveis entre os três tipos de parto (Grupos EUT, DIST e OCT) ao longo dos períodos avaliados (préparto, intra-parto, pós-parto e $1 \mathrm{~h}$ pós-parto nas parturientes ou ao nascimento, $5 \mathrm{e}$ 60 minutos nos neonatos). O Teste Newman-Keuls foi realizado como teste de comparações múltiplas complementar à ANOVA para identificação da origem das diferenças.

As variáveis também foram submetidas à análise de correlação de Pearson pelo programa SAS System for Windows (SAS, 2000). Foram consideradas diferenças significativas as comparações cujos níveis de significância foram iguais ou menores do que 0,05 ( $p \leq 0,05$ ). 
Resultados 


\section{RESULTADOS}

\subsection{Avaliações maternas}

O período gestacional das fêmeas deste experimento foi, em média, de 278 dias. No Grupo EUT, o tempo médio da segunda fase do parto (ruptura de anexos fetais até a expulsão completa fetal) foi de 2 horas. No Grupo DIST, a fase de expulsão fetal foi, em média, de 3 horas e 30 minutos e no Grupo OCT esta fase foi de 3 horas e 50 minutos. A intervenção obstétrica no Grupo DIST foi iniciada aproximadamente em 3 horas e 30 minutos após a ruptura dos anexos fetais, e a expulsão fetal completa ocorreu em no máximo 5 minutos após o início do procedimento. A terapia ecbólica com ocitocina resultou na expulsão fetal imediata em 2 casos. Nos demais (8) houve necessidade de leve auxílio manual, com expulsão fetal em até 30 minutos do término da infusão.

Todos os grupos apresentaram elevada freqüência cardíaca, com valores médios entre $87 \pm 16 \mathrm{bpm}$ a $111 \pm 23 \mathrm{bpm}$ (Tabela 5). A freqüência cardíaca no Grupo OCT foi estatisticamente superior no pós-parto em relação ao período préparto. Não houve diferença significativa entre os demais períodos e grupos analisados (Tabela 5).

Tabela 5 - Média e desvio-padrão da freqüência cardíaca (bpm) em vacas Holandesas no periparto - São Paulo - 2008

\begin{tabular}{cccc}
\hline & GRUPO EUT & GRUPO DIST & GRUPO OCT \\
\hline Pré-parto & $107 \pm 19$ & $105 \pm 10$ & $94 \pm 11^{\mathrm{b}}$ \\
Intra-parto & $106 \pm 12$ & $103 \pm 17$ & $91 \pm 21^{\mathrm{ab}}$ \\
Pós-parto & $97 \pm 16$ & $103 \pm 14$ & $111 \pm 23^{\mathrm{a}}$ \\
1h pós-parto & $87 \pm 16$ & $104 \pm 12$ & $90 \pm 10^{\mathrm{ab}}$ \\
\hline a,b diferença significativa na mesma coluna $(\mathrm{p} \leq 0,05)$ &
\end{tabular}


Com relação à pressão arterial não invasiva (PA), as fêmeas bovinas permaneceram normotensas durante todo o período de avaliação e não houve diferença estatística segundo a condição obstétrica.

No Grupo DIST, a PA sistólica no intra-parto foi estatisticamente mais elevada, comparando-se a 1 hora pós-parto (Tabela 6). Com relação à PA diastólica, o intra-parto dos Grupos EUT e DIST foi estatisticamente superior ao pré-parto. Entretanto, nos Grupos DIST e OCT, houve queda significativa da PA diastólica no pós-parto imediato em relação ao intra-parto (Tabela 6).

Tabela 6 - Média e desvio-padrão da pressão arterial sistólica $(\mathrm{mmHg})$ e diastólica $(\mathrm{mmHg})$ em vacas Holandesas no periparto - São Paulo, - 2008

\begin{tabular}{lcccc}
\hline & & GRUPO EUT & GRUPO DIST & GRUPO OCT \\
\hline \multirow{2}{*}{ PA sistólica } & Pré-parto & $109 \pm 21$ & $111 \pm 18^{\mathrm{ab}}$ & $125 \pm 33$ \\
& Intra-parto & $117 \pm 37$ & $138 \pm 34^{\mathrm{a}}$ & $124 \pm 20$ \\
& Pós-parto & $117 \pm 28$ & $112 \pm 23^{\mathrm{ab}}$ & $98 \pm 23$ \\
& 1h pós-parto & $107 \pm 25$ & $102 \pm 12^{\mathrm{b}}$ & $114 \pm 22$ \\
\hline \multirow{2}{*}{ PA diastólica } & Pré-parto & $46 \pm 11^{\mathrm{b}}$ & $51 \pm 10^{\mathrm{b}}$ & $68 \pm 18^{\mathrm{ab}}$ \\
& Intra-parto & $70 \pm 19^{\mathrm{a}}$ & $83 \pm 19^{\mathrm{a}}$ & $83 \pm 13^{\mathrm{a}}$ \\
& Pós-parto & $61 \pm 16^{\mathrm{ab}}$ & $55 \pm 14^{\mathrm{b}}$ & $56 \pm 12^{\mathrm{b}}$ \\
& 1h pós-parto & $60 \pm 19^{\mathrm{ab}}$ & $65 \pm 13^{\mathrm{ab}}$ & $65 \pm 17^{\mathrm{ab}}$ \\
\hline a,b diferença significativa na mesma coluna $(\mathrm{p} \leq 0,05)$ & &
\end{tabular}

No G EUT, as PA médias foram: $70 \pm 16$; $82 \pm 26$; $84 \pm 14$ e $71 \pm 15 \mathrm{mmHg}$, respectivamente no pré-parto, intra-parto, pós-parto e 1hora pós-parto (Gráfico 1). No Grupo DIST, a PA média intra-parto $(101 \pm 24 \mathrm{mmHg})$ foi significativamente superior às demais avaliações $(71 \pm 11 ; 72 \pm 16$ e $76 \pm 10 \mathrm{mmHg}$, respectivamente no pré-parto, pós-parto e 1hora pós-parto). Já no Grupo OCT, a PA média intra-parto $(97 \pm 12 \mathrm{mmHg})$ foi estatisticamente superior ao pós-parto $(70 \pm 14 \mathrm{mmHg})$, não 
havendo diferença com as demais repetições $(88 \pm 25 \mathrm{mmHg}$ no pré-parto e $81 \pm 18 \mathrm{mmHg}$ após 1 hora do parto).

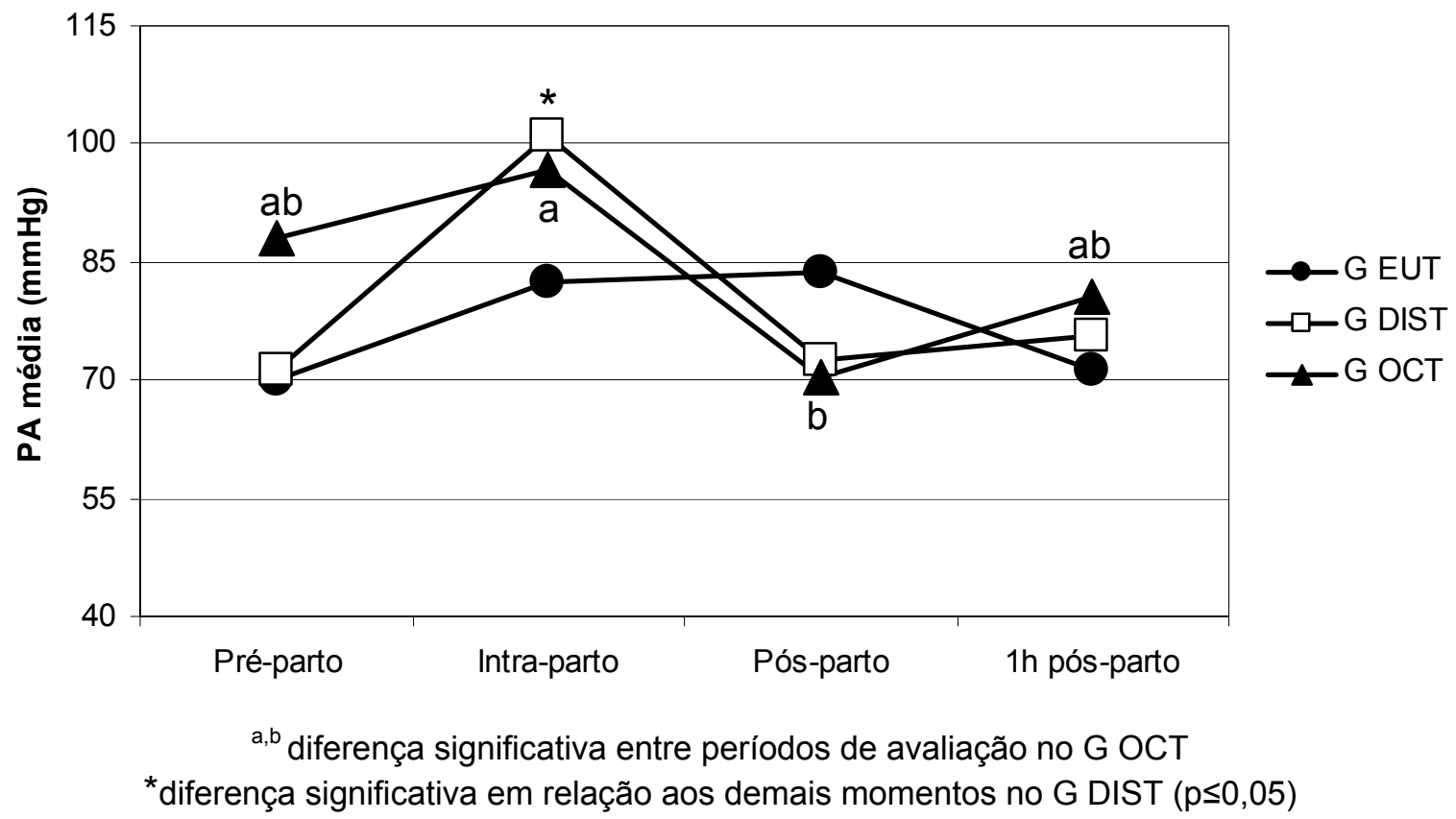

Gráfico 1 - Pressão arterial média de vacas Holandesas no periparto - São Paulo 2008

Os traçados eletrocardiográficos demonstraram ritmo sinusal normal durante as diferentes condições de parto (eutocia, distocia e infusão com ocitocina) e não diferiram durante os períodos de avaliação (Figuras 5 e 6).

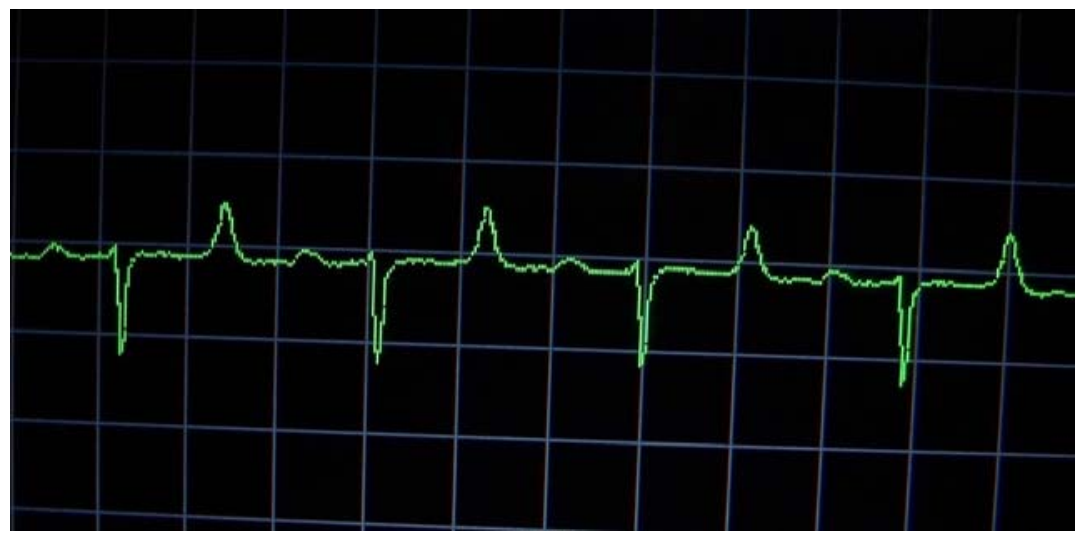

Figura 5 - Ritmo sinusal normal em derivação II 1 hora pós-parto em vaca Holandesa do Grupo DIST 


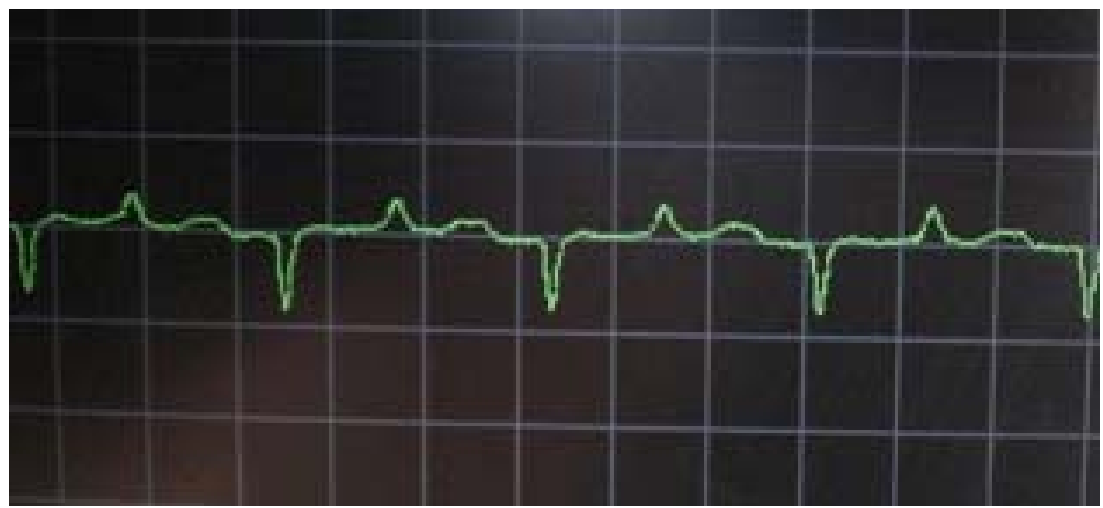

Figura 6 - Ritmo sinusal normal em derivação basoapical pré-parto em vaca Holandesa do Grupo OCT

Em relação à dosagem de glicose sangüínea, os resultados do Grupo OCT 1h pós-parto foram estaticamente inferiores aos dos Grupos EUT e DIST. No intraparto, o Grupo DIST apresentou superioridade estatística ao Grupo EUT (Tabela 7).

Tabela 7 - Média e desvio-padrão da glicemia $(\mathrm{mg} / \mathrm{dL})$ e cortisol ( $\mathrm{ng} / \mathrm{mL}$ ) em vacas Holandesas no periparto - São Paulo - 2008

\begin{tabular}{ccccc}
\hline & GRUPO EUT & GRUPO DIST & GRUPO OCT \\
\hline \multirow{2}{*}{ Glicemia } & Pré-parto & $60,56 \pm 10,76^{\mathrm{b}}$ & $63,70 \pm 10,61^{\mathrm{c}}$ & $51,44 \pm 10,77^{\mathrm{c}}$ \\
& Intra-parto & $60,56 \pm 7,06^{\mathrm{Bb}}$ & $76,80 \pm 9,50^{\mathrm{Abc}}$ & $63,90 \pm 14,86^{\mathrm{ABbc}}$ \\
& Pós-parto & $71,70 \pm 19,96^{\mathrm{b}}$ & $83,80 \pm 13,68^{\mathrm{ab}}$ & $73,89 \pm 10,88^{\mathrm{ab}}$ \\
& 1h pós-parto & $92,50 \pm 25,04^{\mathrm{Aa}}$ & $94,44 \pm 8,00^{\mathrm{Aa}}$ & $79,40 \pm 15,89^{\mathrm{Ba}}$ \\
\hline \multirow{3}{*}{ Cortisol } & Pré-parto & $16,38 \pm 3,36^{\mathrm{b}}$ & $15,36 \pm 6,45^{\mathrm{b}}$ & $13,06 \pm 8,36^{\mathrm{b}}$ \\
& Intra-parto & $29,64 \pm 11,68^{\mathrm{a}}$ & $21,28 \pm 6,71^{\mathrm{b}}$ & $19,87 \pm 7,04^{\mathrm{ab}}$ \\
& Pós-parto & $26,79 \pm 9,78^{\mathrm{Bab}}$ & $42,39 \pm 18,04^{\mathrm{Aa}}$ & $24,85 \pm 6,66^{\mathrm{Ba}}$ \\
& 1h pós-parto & $33,94 \pm 8,61^{\mathrm{a}}$ & $35,75 \pm 6,25^{\mathrm{a}}$ & $25,85 \pm 9,87^{\mathrm{a}}$ \\
\hline $\begin{array}{c}\text { A,B diferença significativa na mesma linha }(\mathrm{p} \leq 0,05) \\
\text { a,b,c } \text { diferença significativa na mesma coluna }(\mathrm{p} \leq 0,05)\end{array}$ & &
\end{tabular}


$\mathrm{Na}$ avaliação realizada $1 \mathrm{~h}$ pós-parto, o Grupo EUT apresentou resultados de glicemia estatisticamente superiores aos demais períodos. No Grupo DIST e OCT, a glicemia pós-parto e após 1 hora foram significativas e superiores à avaliação préparto. Os resultados, nestes dois grupos, aumentaram de forma gradativa. Nas distocias corrigidas por extração forçada (Grupo DIST), as vacas apresentaram hiperglicemia já durante o intra-parto, mantendo-se até 1 h pós-parto. Por outro lado, observou-se hiperglicemia apenas $1 \mathrm{~h}$ pós-parto no Grupo EUT e OCT (Tabela 7).

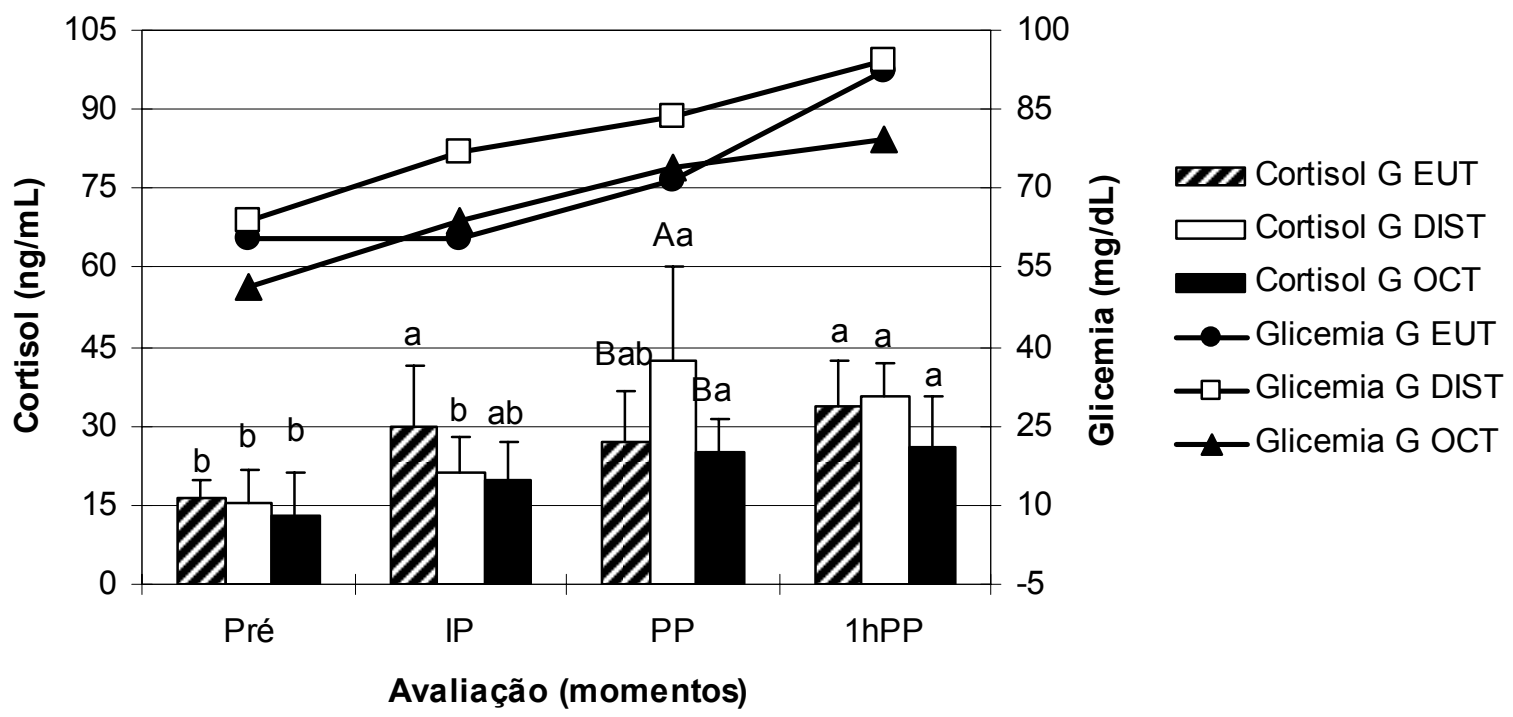

$A, B$ diferença significativa entre grupos dentro do mesmo momento de avaliação $(p \leq 0,05)$
$a, b$ diferença significativa entre momentos de avaliação no mesmo grupo $(p \leq 0,05)$

Gráfico 2 - Concentração de cortisol e glicose de vacas Holandesas no periparto São Paulo - 2008

As vacas do Grupo DIST no pós-parto imediato apresentaram níveis de cortisol estatisticamente mais elevados que os demais grupos (Tabela 7). 0 cortisol sérico durante o intra-parto no Grupo EUT foi estatisticamente superior apenas ao pré-parto; porém sem diferença significativa com os demais momentos. Já no Grupo DIST, a elevação significativa do cortisol ocorreu no pós-parto imediato, permanecendo $1 \mathrm{~h}$ pós-parto. No perfil de cortisol sérico do Grupo OCT, os resultados do pós-parto e $1 \mathrm{~h}$ pós-parto foram estatisticamente superiores ao préparto (Tabela 7 e Gráfico 2). 
Todos os grupos obstétricos apresentaram correlação linear de Pearson positiva entre as concentrações de glicemia e cortisol nos distintos momentos avaliados: Grupo EUT $(0,38 ; p=0,02)$, Grupo DIST $(0,59 ; p<0,01)$ e Grupo OCT $(0,30 ; p=0,06)$.

\subsection{Avaliações neonatais}

A temperatura corpórea de todos os bezerros permaneceu dentro dos padrões de normalidade ao nascimento $\left(39,67 \pm 0,4^{\circ} \mathrm{C} ; 39,83 \pm 0,4^{\circ} \mathrm{C}\right.$ e $39,77 \pm 0,5^{\circ} \mathrm{C}$ para os grupos EUT, DIST e OCT, respectivamente), aos 5 minutos $\left(39,40 \pm 0,7^{\circ} \mathrm{C} ; 39,61 \pm 0,5^{\circ} \mathrm{C}\right.$ e $39,65 \pm 0,6{ }^{\circ} \mathrm{C}$, respectivamente) e mesmo após significativa redução aos 60 minutos $\left(38,30 \pm 0,8^{\circ} \mathrm{C} ; 38,43 \pm 0,4^{\circ} \mathrm{C}\right.$ e $38,21 \pm 0,6^{\circ} \mathrm{C}$, respectivamente) (Gráfico 3).

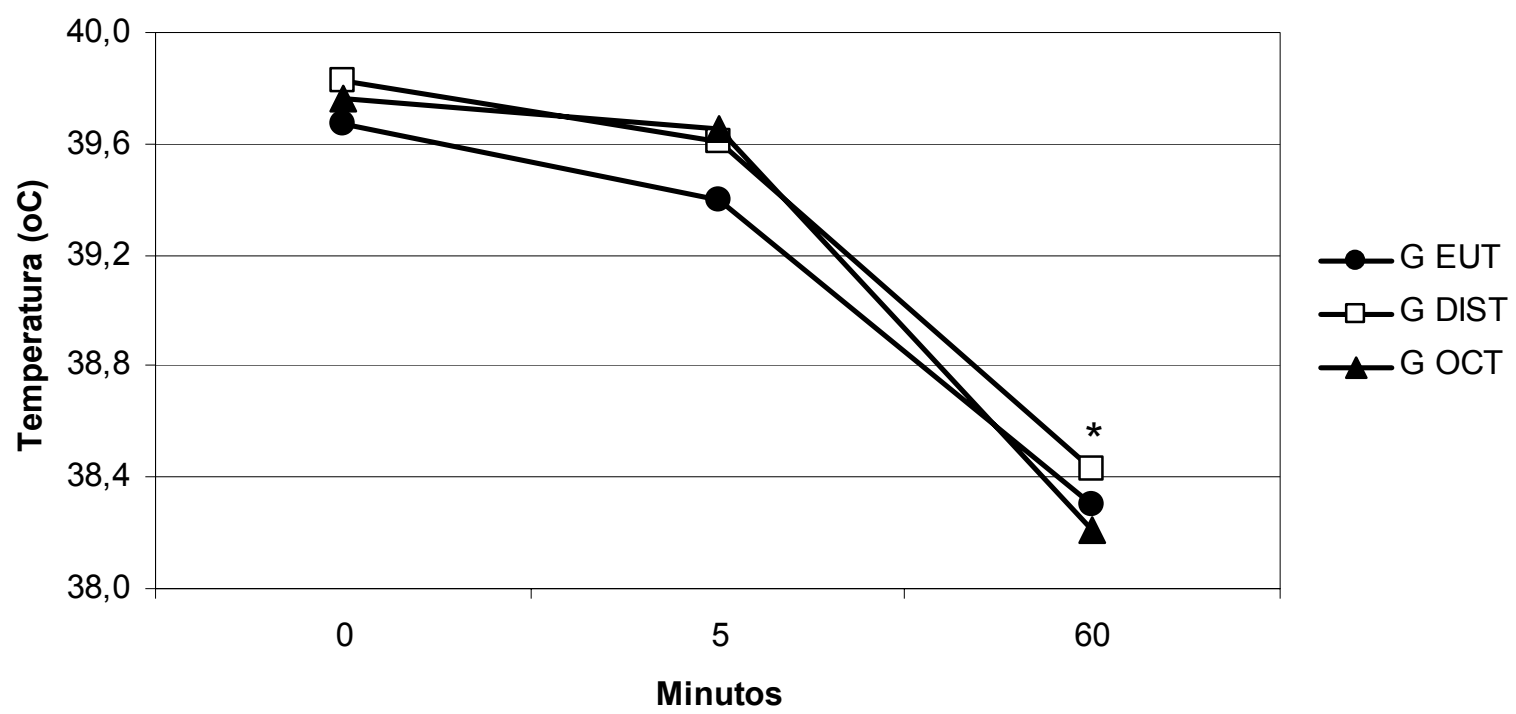

* diferença significativa em relação aos demais momentos em todos os grupos $(p \leq 0,05)$

Gráfico 3 - Temperatura corpórea $\left({ }^{\circ} \mathrm{C}\right)$ de bezerros Holandeses imediatamente após o parto, aos 5 e 60 minutos - São Paulo - 2008 
O Grupo DIST apresentou, estatisticamente, os menores escores de vitalidade Apgar ao nascimento $(4,7 \pm 0,7)$ e após 5 minutos $(7,3 \pm 1,4)$, comparando-se aos Grupos EUT (6,6 \pm 2,1 ao nascimento e 9,1 \pm 1,0 após 5 minutos) e OCT (6,1 \pm 1,9 ao nascimento e 9,0 $\pm 1,0$ após 5 minutos). Após 60 minutos do parto, todos os neonatos receberam notas Apgar semelhantes $(10,0 \pm 0,0 ; 9,3 \pm 1,1 ; 9,9 \pm 0,3$, respectivamente nos G EUT, G DIST e G OCT). Ao nascimento, o escore Apgar nos Grupos EUT e OCT foi estatisticamente inferior ao verificado após 5 e 60 minutos do parto. Entretanto, no Grupo DIST, os resultados diferiram nos três momentos, em ordem crescente a partir do nascimento (Gráfico 4). Os valores médios das freqüências respiratória e cardíaca mensuradas durante a avaliação do escore de vitalidade Apgar estão descritas na tabela 8.

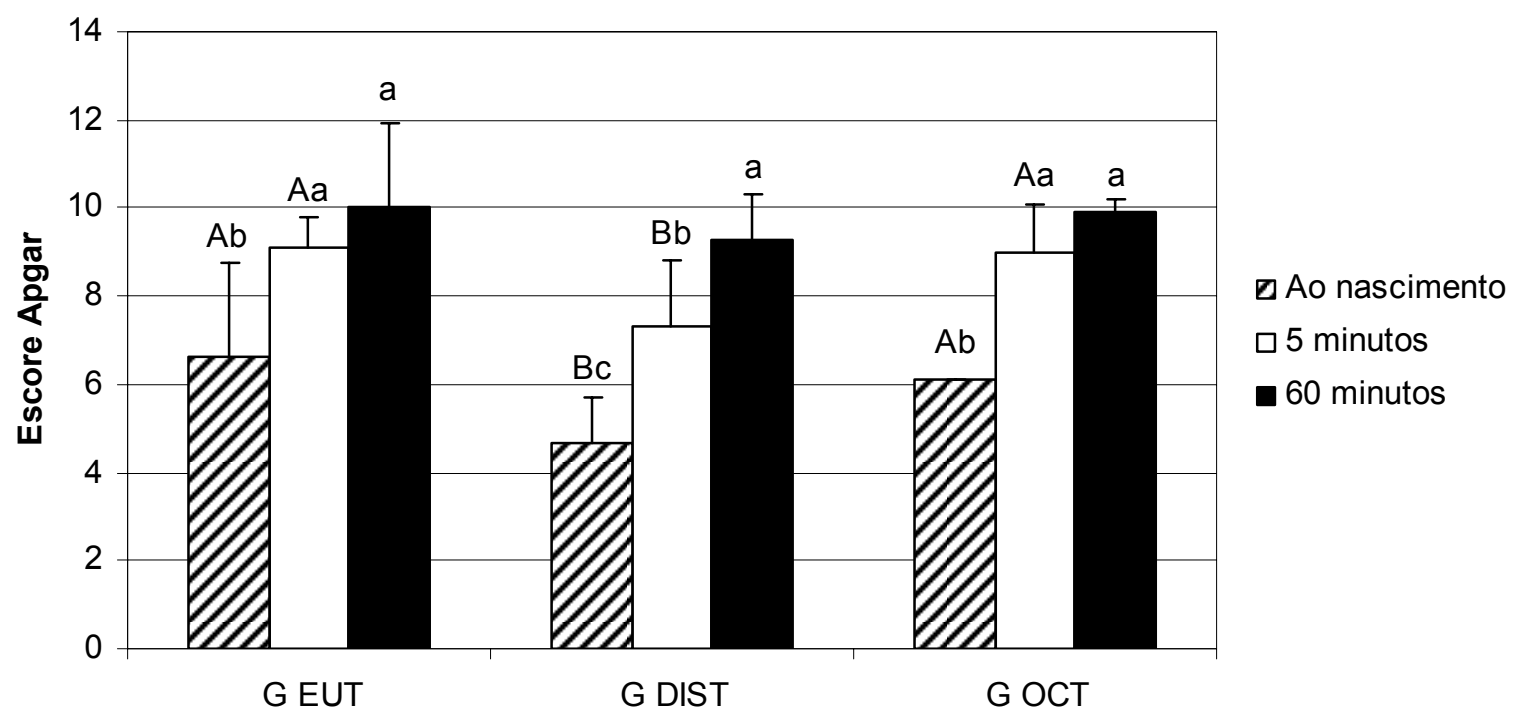

\footnotetext{
${ }^{A, B}$ diferença significativa entre grupos dentro do mesmo período de avaliação $(p \leq 0,05)$ ${ }^{a, b}$ diferença significativa entre períodos de avaliação no mesmo grupo $(p \leq 0,05)$
}

Gráfico 4 - Escore de vitalidade Apgar de bezerros Holandeses imediatamente após o parto, aos 5 e 60 minutos - São Paulo - 2008 
Tabela 8 - Média e desvio-padrão da freqüência respiratória ( $\mathrm{mpm}$ ) e cardíaca (bpm) em bezerros Holandeses ao nascimento e após 60 minutos - São Paulo $-2008$

\begin{tabular}{ccccc}
\hline & & GRUPO EUT & GRUPO DIST & GRUPO OCT \\
\hline $\begin{array}{c}\text { Freqüência } \\
\text { respiratória }\end{array}$ & Ao nascimento & $50,8 \pm 15,5$ & $40,0 \pm 13,1$ & $45,8 \pm 13,7$ \\
\hline $\begin{array}{c}\text { Freqüência } \\
\text { cardíaca }\end{array}$ & Ao nascimento & $133,6 \pm 47,3$ & $135,6 \pm 51,6$ & $123,2 \pm 34,5$ \\
\hline
\end{tabular}

Ao nascimento, o pH sangüíneo dos bezerros do Grupo DIST apresentou-se estatisticamente inferior em comparação aos Grupos EUT e OCT (Tabela 9). Também houve diferença estatística entre os grupos OCT e EUT. Após 60 minutos, não evidenciou-se diferença entre os grupos. Comparando-se os períodos de avaliação, nota-se que após 60 minutos os resultados de pH são estatisticamente superiores em todos os grupos experimentais avaliados (Tabela 9).

Em relação à $\mathrm{pCO}_{2}$ e $\mathrm{pO}_{2}$ ao nascimento, o Grupo OCT apresentou valores superiores e inferiores, respectivamente, ao Grupo EUT. Já os resultados de $\mathrm{HCO}_{3}$, $\mathrm{BE}$ e $\mathrm{TCO}_{2}$ ao nascimento foram estatisticamente inferiores no Grupo DIST em relação aos demais grupos e à avaliação realizada após 60 minutos. Não foram observadas diferenças significativas da $\mathrm{SO}_{2}$ e Anion Gap entre os grupos e momentos de avaliação (Tabela 9). 
Tabela 9 - Média e desvio-padrão da hemogasometria arterial em bezerros Holandeses ao nascimento e após 60 minutos - São Paulo - 2008

\begin{tabular}{|c|c|c|c|c|}
\hline & & GRUPO EUT & GRUPO DIST & GRUPO OCT \\
\hline \multirow{2}{*}{$\mathrm{pH}$} & Ao nascimento & $7,29 \pm 0,08^{A b}$ & $7,18 \pm 0,11^{\mathrm{Cb}}$ & $7,25 \pm 0,04^{\mathrm{Bb}}$ \\
\hline & 60 minutos & $7,34 \pm 0,03^{a}$ & $7,30 \pm 0,07^{a}$ & $7,32 \pm 0,04^{a}$ \\
\hline $\mathrm{pCO}_{2}$ & Ao nascimento & $51,88 \pm 7,9^{\mathrm{Ba}}$ & $53,42 \pm 8,4^{B}$ & $58,69 \pm 5,4^{\mathrm{Aa}}$ \\
\hline$(\mathrm{mmHg})$ & 60 minutos & $45,14 \pm 10,3^{\mathrm{Bb}}$ & $49,40 \pm 8,0^{A B}$ & $51,31 \pm 6,8^{A b}$ \\
\hline \multirow{2}{*}{$\begin{array}{c}\mathbf{p O}_{2} \\
(\mathrm{mmHg})\end{array}$} & Ao nascimento & $55,78 \pm 9,3^{A}$ & $50,80 \pm 18,2^{A B}$ & $37,29 \pm 9,7^{B}$ \\
\hline & 60 minutos & $52,60 \pm 17,5$ & $48,80 \pm 16,7$ & $41,33 \pm 9,1$ \\
\hline \multirow{2}{*}{$\begin{array}{c}\mathrm{HCO}_{3} \\
(\mathrm{mmol} / \mathrm{L})\end{array}$} & Ao nascimento & $21,84 \pm 5,0^{A}$ & $19,17 \pm 8,1^{\mathrm{Bb}}$ & $23,53 \pm 4,4^{\mathrm{A}}$ \\
\hline & 60 minutos & $23,22 \pm 5,5$ & $23,29 \pm 6,8^{a}$ & $25,52 \pm 2,5$ \\
\hline \multirow{2}{*}{$\begin{array}{c}\text { BE } \\
(\mathrm{mmol} / \mathrm{L})\end{array}$} & Ao nascimento & $-3,22 \pm 4,8^{A}$ & $-9,10 \pm 10,3^{\mathrm{Bb}}$ & $-1,67 \pm 3,7^{A}$ \\
\hline & 60 minutos & $-1,33 \pm 4,7$ & $-1,33 \pm 6,3^{a}$ & $-0,44 \pm 2,3$ \\
\hline \multirow{2}{*}{$\begin{array}{c}\mathrm{TCO}_{2} \\
(\mathrm{mmol} / \mathrm{L})\end{array}$} & Ao nascimento & $23,3 \pm 5,3^{A}$ & $20,6 \pm 8,3^{\mathrm{Bb}}$ & $25,14 \pm 4,2^{A}$ \\
\hline & 60 minutos & $24,5 \pm 5,7$ & $24,7 \pm 7,0^{a}$ & $26,8 \pm 2,6$ \\
\hline $\mathrm{SO}_{2}$ & Ao nascimento & $74,7 \pm 8,0$ & $60,3 \pm 19,2$ & $60,7 \pm 10,7$ \\
\hline$(\%)$ & 60 minutos & $77,3 \pm 11,3$ & $69,1 \pm 16,7$ & $70,2 \pm 16,3$ \\
\hline Anion & Ao nascimento & $12,0 \pm 5,4$ & $12,2 \pm 10,3$ & $11,4 \pm 6,3$ \\
\hline Gap & 60 minutos & $8,8 \pm 5,0$ & $12,2 \pm 7,3$ & $10,9 \pm 2,5$ \\
\hline
\end{tabular}

A concentração sangüínea de $\mathrm{Na}^{+}$no Grupo OCT foi estatisticamente superior ao Grupo DIST ao nascimento e ao Grupo EUT após 60 minutos (Tabela 10). As concentrações de $\mathrm{K}^{+}$não diferiram ao longo do tempo ou segundo a condição obstétrica. Em relação ao nível de $\mathrm{Cl}^{-}$, o Grupo OCT apresentou resultados estatisticamente superiores ao Grupo EUT nos dois momentos de avaliação (Tabela 10). 
Tabela 10 - Média e desvio-padrão da concentração de íons ( $\mathrm{mmol} / \mathrm{L})$ em bezerros Holandeses ao nascimento e após 60 minutos - São Paulo - 2008

\begin{tabular}{ccccc}
\hline & & GRUPO EUT & GRUPO DIST & GRUPO OCT \\
\hline $\mathbf{N a}^{+}$ & Ao nascimento & $132,6 \pm 4,1^{\mathrm{AB}}$ & $130,4 \pm 9,3^{\mathrm{B}}$ & $136,9 \pm 2,0^{\mathrm{A}}$ \\
& 60 minutos & $132,0 \pm 7,7^{\mathrm{B}}$ & $133,9 \pm 4,8^{\mathrm{AB}}$ & $138,5 \pm 1,8^{\mathrm{A}}$ \\
\hline $\mathbf{K}^{+}$ & Ao nascimento & $4,4 \pm 0,8$ & $4,5 \pm 0,9$ & $4,0 \pm 0,4$ \\
& 60 minutos & $4,7 \pm 1,4$ & $4,0 \pm 0,4$ & $3,8 \pm 0,3$ \\
$\mathbf{C l}^{-}$ & Ao nascimento & $102,1 \pm 4,0^{\mathrm{B}}$ & $104,4 \pm 3,2^{\mathrm{AB}}$ & $106,4 \pm 7,0^{\mathrm{A}}$ \\
\hline & 60 minutos & $102,4 \pm 3,4^{\mathrm{B}}$ & $103,3 \pm 2,6^{\mathrm{AB}}$ & $106,1 \pm 3,4^{\mathrm{A}}$ \\
\hline $\mathrm{A}, \mathrm{B}$ diferença significativa na mesma linha & & & &
\end{tabular}

Não foram observadas diferenças estatísticas na concentração de hemoglobina, hematócrito e uréia nitrogenada sangüínea entre os Grupos EUT, DIST e OCT, ao nascimento e após 60 minutos do parto (Tabela 11).

Tabela 11 - Média e desvio-padrão do hematócrito (\%), concentração de hemoglobina $(\mathrm{g} / \mathrm{dL})$ e uréia nitrogenada sangüínea $(\mathrm{mg} / \mathrm{dL})$ em bezerros Holandeses neonatos - São Paulo - 2008

\begin{tabular}{ccccc}
\hline & & GRUPO EUT & GRUPO DIST & GRUPO OCT \\
\hline \multirow{2}{*}{ Hematócrito } & Ao nascimento & $23,2 \pm 6,0$ & $24,4 \pm 9,2$ & $24,1 \pm 3,9$ \\
& 60 minutos & $24,5 \pm 5,8$ & $24,9 \pm 5,4$ & $26,8 \pm 4,9$ \\
\hline \multirow{2}{*}{$\begin{array}{c}\text { Hemog nascimento } \\
\text { Uréia }\end{array}$} & $7,89 \pm 2,0$ & $8,60 \pm 2,7$ & $8,19 \pm 1,3$ \\
nitrogenada & Ao nascimento & $9,3 \pm 3,7$ & $10,2 \pm 2,3$ & $10,9 \pm 4,0$ \\
sangüínea & 60 minutos & $9,5 \pm 3,1$ & $10,7 \pm 2,7$ & $10,4 \pm 3,8$ \\
\hline
\end{tabular}


Os neonatos bovinos apresentaram-se normoglicêmicos durante todo período de experimentação e não houve diferença estatística entre os grupos obstétricos ou momentos (Tabela 12 e Gráfico 5). O cortisol sérico dos bezerros do Grupo DIST foi estatisticamente superior aos Grupos EUT e OCT ao nascimento, não sendo observada diferença após 60 minutos. No G DIST, a concentração de cortisol ao nascimento apresentou-se estatisticamente mais elevada em relação à avaliação após 60 minutos (Tabela 12 e Gráfico 5).

Tabela 12 - Média e desvio-padrão da glicemia (mg/dL) e concentração de cortisol (ng/mL) em bezerros Holandeses neonatos - São Paulo - 2008

\begin{tabular}{ccccc}
\hline & & GRUPO EUT & GRUPO DIST & GRUPO OCT \\
\hline \multirow{2}{*}{ Glicemia } & Ao nascimento & $80,5 \pm 27,4$ & $81,9 \pm 20,2$ & $66,6 \pm 31,3$ \\
& 60 minutos & $62,4 \pm 22,3$ & $65,0 \pm 14,0$ & $53,8 \pm 12,4$ \\
\hline \multirow{2}{*}{ Cortisol } & Ao nascimento & $154,18 \pm 47,4^{\mathrm{B}}$ & $213,01 \pm 82,1^{\mathrm{Aa}}$ & $134,63 \pm 33,8^{\mathrm{B}}$ \\
& 60 minutos & $145,64 \pm 28,4$ & $160,17 \pm 23,7^{\mathrm{b}}$ & $147,06 \pm 53,4$ \\
\hline $\begin{array}{c}\mathrm{A}, \mathrm{B} \text { diferença significativa na mesma linha } \\
\text { a,b }\end{array}$ & $\begin{array}{c}\mathrm{1}(\mathrm{p} \leq 0,05) \\
\text { diferença significativa na mesma coluna }(\mathrm{p} \leq 0,05)\end{array}$ &
\end{tabular}

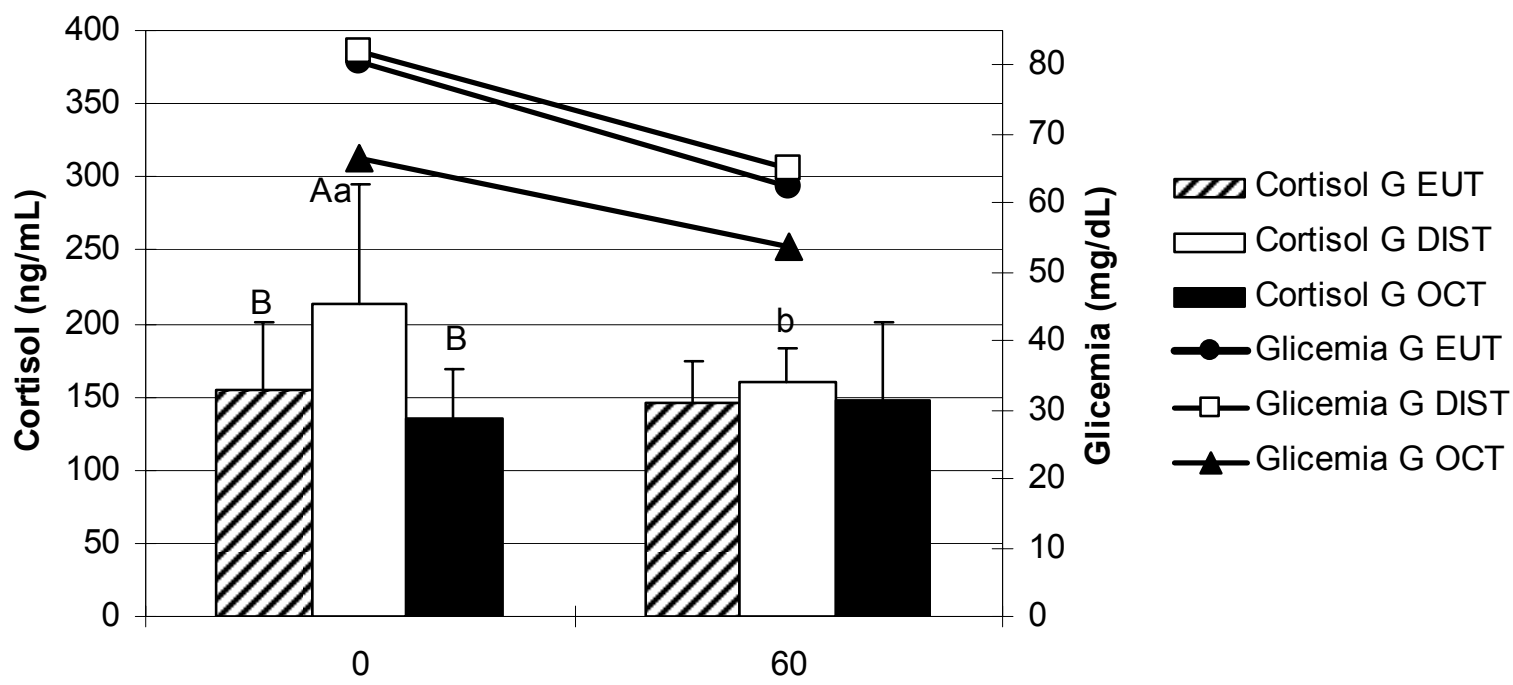

Minutos

$A, B$ diferença significativa entre grupos dentro do mesmo período de avaliação $(p \leq 0,05)$

${ }^{a, b}$ diferença significativa entre períodos de avaliação no mesmo grupo $(p \leq 0,05)$

Gráfico 5 - Concentração de cortisol $(\mathrm{ng} / \mathrm{mL})$ e glicose $(\mathrm{mg} / \mathrm{dL})$ de bezerros Holandeses ao nascimento e após 60 minutos - São Paulo - 2008 
Nos grupos EUT, OCT e DIST, as correlações existentes entre as variáveis neonatais estão descritas na tabela 13, 14 e 15, respectivamente.

Tabela 13 - Correlações de Pearson significativas $(p \leq 0,05)$ para neonatos Holandeses do G EUT até 60 minutos de vida - São Paulo - 2008

\begin{tabular}{cccc}
\hline & & $\mathbf{r}$ & $\mathbf{p}$ \\
\hline $\mathrm{Apgar}$ & $\mathrm{pCO}_{2}$ & $-0,516$ & 0,028 \\
$\mathrm{pH}$ & Anion gap & $-0,608$ & 0,007 \\
$\mathrm{pH}$ & $\mathrm{K}^{+}$ & 0,553 & 0,021 \\
$\mathrm{pCO}_{2}$ & $\mathrm{pO}_{2}$ & $-0,438$ & 0,054 \\
$\mathrm{pCO}_{2}$ & $\mathrm{~K}^{+}$ & $-0,663$ & 0,002 \\
$\mathrm{pO}_{2}$ & $\mathrm{SO}_{2}$ & 0,804 & 0,000 \\
$\mathrm{HCO}_{3}^{-}$ & $\mathrm{TCO}_{2}$ & 0,997 & 0,000 \\
$\mathrm{HCO}_{3}^{-}$ & $\mathrm{BE}^{-}$ & 0,972 & 0,000 \\
$\mathrm{BE}^{-}$ & $\mathrm{TCO}_{2}$ & 0,958 & 0,000 \\
$\mathrm{Hb}$ & $\mathrm{Ht}$ & 0,999 & 0,000 \\
\hline
\end{tabular}

Tabela 14 - Correlações de Pearson significativas $(p \leq 0,05)$ para neonatos Holandeses do G OCT até 60 minutos de vida - São Paulo - 2008

\begin{tabular}{cccc}
\hline & & $\mathbf{r}$ & $\mathbf{p}$ \\
\hline Apgar & $\mathrm{Temp}$ & $-0,416$ & 0,030 \\
$\mathrm{Apgar}$ & $\mathrm{pH}$ & 0,687 & 0,004 \\
$\mathrm{Apgar}$ & $\mathrm{pCO}_{2}$ & $-0,506$ & 0,045 \\
$\mathrm{pH}$ & $\mathrm{pCO}_{2}$ & $-0,690$ & 0,004 \\
$\mathrm{pCO}_{2}$ & $\mathrm{pO}_{2}$ & $-0,514$ & 0,041 \\
$\mathrm{pO}_{2}$ & $\mathrm{SO}_{2}$ & 0,927 & 0,000 \\
$\mathrm{HCO}_{3}^{-}$ & $\mathrm{TCO}_{2}$ & 0,996 & 0,000 \\
$\mathrm{HCO}_{3}^{-}$ & $\mathrm{BE}^{-}$ & 0,969 & 0,000 \\
$\mathrm{HCO}_{3}^{-}$ & $\mathrm{Cl}^{-}$ & $-0,513$ & 0,050 \\
$\mathrm{BE}^{-}$ & $\mathrm{TCO}_{2}$ & 0,952 & 0,000 \\
\hline
\end{tabular}


Tabela 15 - Correlações de Pearson significativas $(p \leq 0,05)$ para neonatos Holandeses do G DIST até 60 minutos de vida - São Paulo - 2008

\begin{tabular}{|c|c|c|c|}
\hline & & $\mathbf{r}$ & $\mathbf{p}$ \\
\hline Apgar & Temp & $-0,660$ & 0,000 \\
\hline Apgar & BE & 0,456 & 0,056 \\
\hline Apgar & Cortisol & $-0,481$ & 0,043 \\
\hline Glicemia & Temp & 0,576 & 0,010 \\
\hline $\mathrm{pH}$ & $\mathrm{BE}$ & 0,911 & 0,000 \\
\hline $\mathrm{pH}$ & $\mathrm{HCO}_{3}^{-}$ & 0,865 & 0,000 \\
\hline $\mathrm{pH}$ & $\mathrm{TCO}_{2}$ & 0,857 & 0,000 \\
\hline $\mathrm{pH}$ & Apgar & 0,549 & 0,022 \\
\hline $\mathrm{pH}$ & $\mathrm{Na}^{+}$ & 0,513 & 0,029 \\
\hline $\mathrm{pH}$ & $\mathrm{Ht}$ & 0,510 & 0,030 \\
\hline $\mathrm{pO}_{2}$ & $\mathrm{SO}_{2}$ & 0,823 & 0,000 \\
\hline $\mathrm{HCO}_{3}^{-}$ & $\mathrm{TCO}_{2}$ & 0,999 & 0,000 \\
\hline $\mathrm{HCO}_{3}{ }^{-}$ & $\mathrm{BE}$ & 0,993 & 0,000 \\
\hline $\mathrm{BE}$ & $\mathrm{TCO}_{2}$ & 0,991 & 0,000 \\
\hline $\mathrm{Hb}$ & $\mathrm{Ht}$ & 0,962 & 0,000 \\
\hline
\end{tabular}


Díscussão






\section{DISCUSSÃO}

\subsection{Alterações hemodinâmicas maternas}

Durante a gestação e parto, a adequada modulação cardíaca é necessária, uma vez que há maior demanda de oxigênio para os tecidos maternos e fetais, simultaneamente à redução do hematócrito por aumento da volemia materna. Ao final da gestação, a diminuição da resistência vascular periférica por ação de hormônios placentários impõe emergente mecanismo de compensação hemodinâmica com o intuito de preservar a pressão arterial (PONTES JR; ANDRADE, 2000). Exige-se, portanto, como requerimento fisiológico a elevação do débito cardíaco, maior volume de ejeção cardíaca e, conseqüentemente, aumento da freqüência cardíaca (PATTON et al., 1989). No presente experimento, observouse elevação da freqüência cardíaca durante o periparto em todos os grupos experimentais. Embora a manipulação das fêmeas durante o exame cardiológico possa alterar as variáveis estudadas, sabe-se que as modulações são momentâneas, não persistentes e sensíveis especialmente a situações de estresse intenso (LEFCOURT et al., 1999). Por este motivo, infere-se que a elevação do batimento cardíaco nas fêmeas avaliadas seja reflexo do mecanismo de compensação fisiológico às mudanças hemodinâmicas impostas pela gestação e parto.

Por outro lado, a freqüência cardíaca do Grupo OCT elevou-se estatisticamente no pós-parto imediato, em comparação ao pré-parto. A meia-vida da ocitocina sintética é curta, em função de sua natureza polipeptídica, com ação de aproximadamente 22 minutos em administrações intra-venosas (HOMEIDA et al., 1984). Por este motivo, os possíveis efeitos cronotrópicos e inotrópicos negativos da ocitocina foram evidentes apenas no intra-parto. Desta forma, acredita-se que a ocitocina exógena exerceu efeito bradicárdico no intra-parto, uma vez que logo após o término de sua ação a freqüência cardíaca elevou-se significativamente ao mensurado antes do parto.

Em mulheres gestantes, observa-se aumento da freqüência cardíaca, débito cardíaco, volume sangüíneo e diminuição da reserva cardíaca e volume celular, 
sem, entretanto, haver alterações na pressão arterial (GREENE, 1995). De forma semelhante, as fêmeas bovinas mantiveram-se normotensas durante todo período de experimentação, não obstante o decréscimo da resistência vascular periférica. Assume-se, portanto, que o aumento da freqüência cardíaca seja fundamental para a manutenção da PA em fêmeas bovinas no pré-parto.

Ao considerar as condições de parto, nota-se que as PAs durante o intraparto do Grupo DIST foram superiores aos demais momentos, especialmente a diastólica e média. Embora tais valores estivessem nos limites de referência, demonstram haver um reflexo tensional preservado para aumento na contração sistólica durante o parto. As forças expulsivas mais acentuadas pela distocia promovem aumento do débito cardíaco e volume sangüíneo circulante, desencadeando elevação da pressão diastólica. Quando o parto inicia-se, o débito cardíaco e o retorno venoso aumentam a cada contração uterina e abdominal, conforme o sangue é impulsionado para o exterior do compartimento uterino (LANDIM-ALVARENGA, 2006).

No momento da expulsão fetal, a pressão diastólica pode elevar-se agudamente, por haver compressão da aorta terminal e artérias ilíacas (PONTES; ANDRADE, 2000). De fato, a permanência fetal no conduto pélvico por tempo prolongado durante a distocia promoveu elevação significativa da PA diastólica no intra-parto das fêmeas do Grupo DIST. Por outro lado, observou-se queda significativa da PA diastólica e média nos grupos DIST e OCT logo após a expulsão fetal (pós-parto imediato). Nos referidos grupos, a expulsão fetal ocorreu abruptamente, seja por extração manual (Grupo DIST) ou ação ecbólica (Grupo OCT). Nestes casos, acredita-se haver descompressão vascular brusca e, portanto, drástica diminuição da resistência vascular periférica e conseqüente alteração pressórica. Já durante a eutocia, a expulsão fetal ocorre de forma lenta e progressiva, permitindo adequada adaptação cardiovascular, mesmo sob influência da intensa algesia.

Com relação à PA sistólica, o grupo DIST apresentou queda significativa apenas 1 hora após o parto, comparando-se à PA intra-parto. Após a descompressão brusca de vasos abdominais no parto, o débito cardíaco aumenta para manter a PA sistólica elevada. Após a expulsão fetal, portanto, a compensação necessária transcorre de forma lenta, observada apenas após 1 hora do parto.

Com base nesta análise global das alterações hemodinâmicas, preconiza-se 
estabelecer um protocolo de conduta para o auxílio obstétrico que tenha como base a higidez neonatal e a duração da assistência. As manobras de extração forçada fetal executadas de forma lenta podem promover asfixia fetal grave, embora permita melhor adaptação anatômica das vias fetais e hemodinâmica à descompressão abdominal. Já a rápida tração fetal exige adaptação hemodinâmica brusca e impõe a higidez cardiovascular das fêmeas bovinas.

Os efeitos cronotrópicos e inotrópicos negativos da ocitocina, verificados anteriormente por Mukaddam-Daher et al. (2001) em cães, foram pontualmente verificados neste estudo. A ação intrínseca direta da ocitocina em receptores cardíacos promove hipotensão por liberação de acetilcolina (MUKADDAM-DAHER et al., 2001). Durante o intra-parto, as fêmeas do Grupo OCT não apresentaram aumento significativo da PA diastólica em relação ao pré-parto, conforme observado nos Grupos EUT e DIST. Contrariamente, esperava-se evidenciar hipertensão arterial no intra-parto do Grupo OCT, em função da maior compressão vascular imposta pela ação ecbólica da ocitocina exógena. Portanto, é possível inferir que a ação hipotensora da ocitocina tenha evitado os efeitos vasculares secundários às contrações uterinas.

Nos traçados eletrocardiográficos (ECG), observou-se ritmo sinusal normal durante todo experimento. Não houve influência da condição obstétrica sobre o ritmo cardíaco das fêmeas bovinas no periparto. O ECG de bovinos é distinto do padrão humano ou canino, em função das características anatômicas e fisiológicas do coração bovino. Neste experimento, a aplicação de duas derivações nos eletrocardiogramas objetivou a visibilização do melhor padrão de transmissão de ondas elétricas. Segundo Claxton (1988), as arritmias na espécie bovina não são comuns e normalmente ocorrem secundariamente a alguma afecção, tais como arritmia sinusal, fibrilação atrial, contração ventricular prematura, flutter atrial e dissociação átrio-ventricular. A fibrilação atrial é a arritmia mais comum, podendo ser orgânica (endocardite, pericardite) ou funcional. A arritmia sinusal, comum em cães, e associada à respiração não é evidente em bovinos, como também não foram observada neste experimento. 


\subsection{Vitalidade neonatal (Escore Apgar e Temperatura corpórea)}

No presente estudo, todos os bezerros apresentaram normotermia, independente da condição obstétrica, mesmo em distintas temperaturas ambientais e após a redução significativa da temperatura corpórea aos 60 minutos de vida. Os neonatos possuem um mecanismo peculiar de termorregulação corpórea, por meio da produção de calor a partir da oxidação do tecido adiposo marrom de localização peri-renal (LANDIM-ALVARENGA, 2006). Os adipócitos deste particular tecido possuem gotas lipídicas multifocais que os distinguem do tecido adiposo branco ou comum, além da maior concentração de mitocôndrias e vasos sangüíneos (CARSTENS, 1994).

A manutenção da temperatura corpórea dos bezerros também pode ser alcançada pelo aumento da atividade metabólica, representada pela capacidade de tremor, e por controle vascular, para reduzir o fluxo sangüíneo para as extremidades e pele. A maturidade dos centros regulatórios e a plasticidade vascular ao nascimento regulam a homeotermia dos bezerros (BATCHELDER et al., 2007). Ademais, a densa pelagem ao nascimento funciona como uma barreira à entrada de ar e resistência às perdas de calor. Entretanto, alta umidade e ventilação excessiva rompem esta camada protetora e podem aumentar a transferência térmica (CARSTENS, 1994).

Bezerros nascidos em distocia apresentam menor habilidade em manter a temperatura corpórea após o parto. Em função da fraqueza neonatal, hipóxia, comprometimento metabólico e do menor fluxo sanguíneo para o tecido adiposo marrom, a atividade termogênica é anormal (CARSTENS, 1994). Entretanto, tais assertivas vão de encontro aos resultados deste experimento, pois não se observou hipotermia nos bezerros dos Grupos DIST e OCT nos distintos momentos de avaliação. A maior produção de catecolaminas durante a distocia pode ser responsável pelo aumento do aporte vascular para o tecido adiposo marrom e, conseqüentemente, maior produção de calor (BELLOWS; LAMMOGLIA, 2000). O maior estresse neonatal observado nos bezerros do grupo DIST corrobora tal condição, favorecendo a resposta orgânica às condições extra-uterinas adversas. Ademais, as altas concentrações de cortisol nos bezerros em distocia apresentam correlação negativa com o escore de vitalidade Apgar. 
A despeito da ativação dos mecanismos de termorregulação, os neonatos nascidos em distocia (G DIST) apresentaram escore Apgar estatisticamente inferior aos Grupos EUT e OCT, portanto, são caracterizados como recém-nascidos de baixa vitalidade ao nascimento. Segundo Diesch et al. (2004), os bezerros nascidos em distocia ou sob hipoxemia apresentam enfraquecimento das funções fisiológicas. De fato, as funções vitais dos bezerros do Grupo DIST evoluíram mais lentamente que os demais grupos, ao atingirem escore Apgar satisfatório (>7) apenas após 60 minutos de vida. Em neonatos caninos nascidos em distocia, Lúcio (2008) detectou depressão das funções vitais ao nascimento e evolução clínica mais lenta, sugerindo que a permanência do filhote no canal vaginal por maior tempo, o descolamento placentário precoce e as contrações uterinas improdutivas sejam as principais causas para a baixa vitalidade ao nascimento.

Em potros, a higidez neonatal é atestada apenas quando o escore Apgar é superior a 9; enquanto escores entre 6 e 8 indicam asfixia moderada, porém com bom prognóstico (VAALA et al., 2006). Contrariamente, bezerros em leve asfixia não apresentam distinção no escore Apgar em relação a bezerros sadios (BENESI, 1992). Desta forma, em bovinos, esta pontuação de vitalidade parece ser subjetiva e passível de falhas, dificultando a aplicação do método. Por outro lado, o sistema de pontuação Apgar pode ser seguramente correlacionado ao equilíbrio ácido-básico nos recém-nascidos (BENESI, 1992). De fato, a menor vitalidade dos bezerros do Grupo DIST observada no presente experimento pôde ser positivamente correlacionada à acidose ao nascimento $(r=0,549 ; p=0,02)$, não verificada nos Grupos EUT e OCT.

O escore Apgar correlacionou-se negativamente à temperatura corpórea nos Grupos DIST e OCT. Acredita-se que tal condição ocorra por disponibilização das reservas energéticas nos bezerros de menor vitalidade em favorecimento da homeotermia e em detrimento das demais funções vitais. A presença de correlação positiva entre a glicemia e a temperatura corpórea nos neonatos do Grupo DIST corrobora esta infrência. 


\subsection{Equilíbrio ácido-básico neonatal}

Em relação à avaliação hemogasométrica dos bezerros ao nascimento, foi possível detectar acidose mista (metabólica e respiratória) no Grupo DIST e alteração dos componentes do equilíbrio ácido-básico nos Grupos EUT e OCT.

Nos bezerros nascidos em eutocia, embora o pH sangüíneo estivesse dentro dos valores de referência, os teores de bicarbonato sangüíneo e o excesso de bases estavam abaixo do normal e a pressão de $\mathrm{CO}_{2}$, elevada. É importante ressaltar que a eutocia também pode promover variados graus de desequilíbrio ácido-base, como conseqüência da isquemia útero-placentária fisiológica durante as contrações expulsivas. Por este motivo, torna-se essencial a análise do Anion Gap, pois este componente da análise hemogasométrica pode denunciar 0 desequilíbrio metabólico, já em processo de compensação, mesmo sem a alteração do pH sangüíneo (KANETO et al., 2004). Ao se analisar tal componente ao nascimento no Grupo EUT ao nascimento, nota-se que o desequilíbrio ácido-base foi estabelecido não obstante o parto normal. Para a compensação do pH sangüíneo, é possível inferir que as bases-tampão do sangue, tais como o bicarbonato e o BE, estão sendo mobilizadas e consumidas para este fim. Disto demonstra a rápida resolução do quadro acidótico instalado durante $o$ parto $e$, por conseguinte, o ótimo prognóstico para bezerros nascidos em eutocia.

Os bezerros do Grupo DIST apresentaram acentuado grau de acidose mista ao nascimento, comparando-se aos Grupos EUT e OCT. Os resultados alterados do BE, $\mathrm{HCO}_{3}^{-}$e Anion Gap confirmam a acidose do tipo metabólica, enquanto os elevados valores de $\mathrm{pCO}_{2}$ caracterizam a acidose respiratória. Após 60 minutos de vida, não obstante a recuperação da acidemia, os componentes metabólicos $\left(\mathrm{HCO}_{3}{ }^{-}\right.$ e Anion Gap) permaneceram alterados. Assume-se, portanto, que em bezerros nascidos em distocia, a compensação metabólica inicia-se somente durante a primeira hora de vida. Nas distocias, o distúrbio da circulação materno-fetal é mais severo e prolongado, determinando acidose mais acentuada, exigindo-se um período de recuperação maior ao imposto para o desequilíbrio metabólico verificado na eutocia (MASSIP, 1980).

Em referência aos bezerros nascidos sob influência da ocitocina (Grupo OCT), nota-se perfil hemogasométrico semelhante aquele do Grupo EUT. Todavia, 
após 60 minutos do parto, o Anion Gap permaneceu alterado, apesar da normalização do $\mathrm{HCO}_{3}{ }^{-}$e $\mathrm{BE}$. O bicarbonato é um dos muitos tampões do sangue que pode ser afetado pelo componente respiratório $\left(\mathrm{pCO}_{2}\right)$, mascarando seu emprego para designar a acidose. De fato, os valores de $\mathrm{pCO}_{2}$ no Grupo OCT foram estatisticamente mais elevados que o Grupo EUT nos dois momentos de avaliação, denotando maior comprometimento respiratório. Em equinos, a indução de contrações uterinas com ocitocina contribui para o agravamento da asfixia periparto, resultando em hipercapnia e anormalidade neonatal (MACPHERSON et al., 1997). Embora a saturação de $\mathrm{O}_{2}$ estivesse normal no Grupo OCT nas duas avaliações, a pressão de $\mathrm{O}_{2}$ ao nascimento apresentou-se significativamente inferior ao Grupo EUT. Sugere-se, portanto, que a administração de ocitocina em bovinos possa comprometer as trocas gasosas placentárias durante o parto, levando à alterações respiratórias dos bezerros ao nascimento. A infusão lenta de ocitocina pode provocar padrões de contração uterina diferenciados do fisiológico, tanto em intensidade como duração, comprometendo ainda mais a circulação, oxigenação e o estresse materno-fetal.

$\mathrm{A} \mathrm{pO}_{2}$ sangüínea sofre influência da concentração de oxigênio inspirado e da freqüência respiratória do recém-nascido. A hipercapnia e acidose respiratória são resultantes da incapacidade dos músculos respiratórios ventilarem adequadamente os pulmões do neonato, bem como por disfunções neurológicas (VAALA et al., 2006), resultantes do sofrimento fetal durante o parto. Portanto, a hipoxemia e hipercapnia verificadas nos bezerros do Grupo OCT ao nascimento podem ser reflexos da maior permanência fetal no conduto pélvico (aproximadamente 4 horas) em comparação aos demais grupos. Entretanto, nota-se recuperação da hipóxia após 60 minutos do parto no Grupo OCT. O desequilíbrio ácido-base em bezerros ao nascimento é capaz de estimular mais efetivamente os quimiorreceptores respiratórios, resultando em melhor conversão de oxigênio (BLEUL et al., 2007).

Os bezerros nascidos em distocia (Grupo DIST) apresentaram alteração mais acentuada do componente metabólico da acidose sangüínea. Tal assertiva pode ser corroborada ao se verificar a correlação positiva existente entre o $\mathrm{pH}$ e os componentes metabólicos $\mathrm{BE}, \mathrm{HCO}_{3}{ }^{-}$e $\mathrm{TCO}_{2}$ neste grupo. Já os neonatos do Grupo OCT demonstraram maior comprometimento respiratório na análise hemogasométrica, pois verificou-se correlação negativa entre o $\mathrm{pH}$ e a $\mathrm{pCO}_{2}$, bem como entre as variáveis respiratórias $\mathrm{pO}_{2}$ e $\mathrm{pCO}_{2}$. Ainda, os bezerros do Grupo OCT 
apresentaram hiperventilação após 60 minutos do parto, representada pelo aumento da freqüência respiratória, como mecanismo reflexo da hipercapnia, não verificado nos Grupos EUT e DIST. Os pulmões podem suscitar rápidas alterações no pH sangüíneo ao eliminar rapidamente $\mathrm{O}^{\mathrm{CO}_{2}}$. Quando a ventilação pulmonar é eficiente, a $\mathrm{pCO}_{2}$ diminui e ocorre menor dissociação do ácido carbônico em íons $\mathrm{H}^{+}$ e $\mathrm{HCO}_{3}{ }^{-}$, aumentando o pH sangüíneo (ROBINSON, 2004). O aumento da freqüência respiratória nos bezerros do Grupo OCT demonstra a sensibilidade dos receptores à hipercapnia instalada, mas não permitiu a normalização da hipercapnia após 60 minutos do parto.

Os mecanismos de controle do equilíbrio ácido-básico e eletrolítico nos recém-nascidos é peculiar desta faixa etária, pois diferenças significativas na metabolização e função renal em relação aos adultos são verificadas. O rim do neonato não é funcionalmente ativo ao nascimento e, portanto, a excreção renal de íons é menos eficiente do que nos adultos (KNOTTENBELT et al., 2006). Desta maneira, a avaliação hidro-eletrolítica é fundamental para predizer eventuais limitações fisiológicas, desidratação e desequilíbrios iônicos, uma vez que os recémnascidos possuem maior superfície corpórea em relação aos adultos (COELHO, 2002). Neste estudo, os bezerros dos distintos grupos experimentais apresentaram normonatremia e normocloremia ao nascimento e após 60 minutos. Tais resultados vão de encontro aos apresentados por Mohri et al. (2007), para os quais os níveis de cloretos séricos são baixos nos recém-nascidos. Nos Grupos OCT e DIST (aos 60 minutos pós-parto), observou-se hipocalemia. De acordo com Dibartola et al. (2006), a liberação de adrenalina durante o estresse do parto e o aumento da insulina promovem maior afluxo de potássio para as células musculares e hepáticas. Quando o desequilíbrio ácido-base é corrigido após 60 minutos do parto, os íons $\mathrm{H}^{+}$intracelulares são substituídos pelo $\mathrm{K}^{+}$, levando à diminuição deste íon no sangue, conforme observado nos Grupos DIST e OCT.

A maioria dos eletrólitos apresenta via de excreção renal e são reabsorvidos ou excretados na dependência de íons $\mathrm{H}^{+}$e do estado ácido-base, tal como o íon potássio; já os cloretos são proporcionais e opostos às taxas de bicarbonato no sangue (COELHO, 2002). De fato, foi possível neste experimento estabelecer correlações entre as concentrações de eletrólitos e as variáveis do equilíbrio ácidobase. Para os bezerros nascidos em eutocia, os níveis de $\mathrm{K}^{+}$correlacionaram 
positivamente ao $\mathrm{pH}$ sangüíneo, enquanto a correlação com a $\mathrm{pCO}_{2}$ foi negativa. No Grupo DIST, os níveis de $\mathrm{Na}^{+}$também apresentaram correlações positivas com o pH sangüíneo. Em condições de acidose, os íons $\mathrm{H}^{+}$são substituídos por íons sódio e potássio intra-celulares, aumentando suas concentrações no sangue (ROBINSON, 2004). Já no Grupo OCT, as concentrações de $\mathrm{Cl}^{-}$correlacionaram-se negativamente ao $\mathrm{HCO}_{3}{ }^{-}$. O íon cloreto $\left(\mathrm{Cl}^{-}\right)$é uma base fraca, pois sua capacidade de associar-se ao $\mathrm{H}^{+}$é pequena. Portanto, trata-se de um sistema complementar aos demais componentes metabólicos compensatórios da acidose (ROBINSON, 2004).

Os bezerros do Grupo OCT apresentaram perfil eletrolítico diferenciado dos demais grupos. O aumento significativo de $\mathrm{Na}^{+}$e $\mathrm{Cl}^{-}$e a hipocalemia nos dois momentos de avaliação permitem atribuir tais resultados à ação hipotensora da ocitocina exógena. Segundo Wallin et al. (1989), a ocitocina é normalmente secretada em conjunto o hormônio anti-diurético (ADH), a partir do hipotálamo. Durante o parto ou em quadros hemorrágicos, o ADH também é liberado como resposta à redução de volume sangüíneo, o que permite a reabsorção de água pelos rins, especialmente através da liberação de renina. Subseqüentemente, há estímulo para a produção de angiotensina II e aldosterona que conjuntamente evitam a excreção renal de $\mathrm{Na}^{+}$. Como conseqüência, a favor de seu gradiente eletroquímico, o $\mathrm{Cl}^{-}$também é reabsorvido e o $\mathrm{K}^{+}$, opostamente, é eliminado de forma ativa pela bomba ATPase- $\mathrm{Na}^{+} / \mathrm{K}^{+}$renal. Ocorre, desta forma, a restauração do volume sangüíneo e a normalização da pressão arterial (STEPHENSON, 2004). Desta maneira, a hipotensão materna durante a infusão de ocitocina pode alterar a distribuição do fluxo sangüíneo materno-fetal e, conseqüentemente, promover hipoperfusão renal e alterações hidro-eletrolíticas neonatais.

Durante a asfixia periparto em casos extremos, a menor perfusão renal resulta em necrose tubular ou até insuficiência renal aguda. Tais alterações podem levar a distúrbios eletrolíticos como hipocloremia e hiponatremia (VAALA et al., 2006). Entretanto, os níveis de uréia nitrogenada para os bezerros do presente estudo encontravam-se normais para o período neonatal, sugerindo adaptabilidade da função renal logo após o nascimento. Ainda, a normonatremia e normocloremia corroboram a adequada função renal dos bezerros nas primeiras horas de vida. Por este motivo, acredita-se que a excreção de íons ocorreu de maneira adequada, permanecendo os níveis séricos dentro dos padrões de normalidade. De acordo com 
Mohri et al. (2007), os níveis de uréia nas primeiras 24-48 horas de vida dos bezerros é semelhante aos dos adultos e suas variações podem ser reflexo da ingestão protéica materna.

Embora não tenham sido observadas diferenças nos resultados do hematócrito e concentração de hemoglobina entre os grupos experimentais e períodos de avaliação neste experimento, os dados hematológicos encontraram-se abaixo dos valores de referência. A hemoglobina está intimamente envolvida com o transporte de gases e captação de íons $\mathrm{H}^{+}$, sendo um dos mais importantes tampões do organismo (LISBÔA, 2000). Portanto, pode-se atribuir tais resultados ao componente metabólico de compensação da acidose no periparto, pois a hemoglogina foi consumida para o sistema tampão sangüíneo. Ainda, o hematócrito apresentou correlação positiva com o pH no Grupo DIST.

Embora a anemia fisiológica em bezerros tenha sido descrita por diversos autores, sua etiologia ainda não está bem definida. É possível citar distintas causas, tais como: alteração da resposta medular ao aumento progressivo da oxigenação sangüínea neonatal; menor vida-útil dos eritrócitos fetais; reduzidas concentrações de eritropoetina e baixa disponibilidade de nutrientes como o ferro. A imaturidade renal em potros pode ter relação com deficiência na produção de eritropoetina e, portanto, com a anemia fisiológica (KNOTTENBELT et al. 2006). De acordo com Benesi (1992), a anemia de bezerros pode decorrer também da hemodiluição por ajustes de fluidos corporais após o nascimento. A hemólise e a deficiência eritropoiética podem ser conseqüências da ação de estrógenos placentários, além da relação com a hipóxia tecidual.

\subsection{Glicemia e cortisol materno e neonatal}

As alterações metabólicas que ocorrem em bovinos durante a gestação, parto e puerpério não promovem alterações diretas no metabolismo da glicose sangüínea (POGLIANI, 2006). No entanto, o parto é um evento fisiológico que envolve algesia e estresse e, portanto, passível de mudanças hormonais, tais como de cortisol, adrenalina, noradrenalina, ocitocina, vasopressina e endorfinas (HYDBRING et al., 
1999). Os glicocorticóides e as catecolaminas são hormônios responsivos ao estresse e estimulam diretamente o metabolismo hepático de carboidratos, como a glicose (CHAN et al., 1993). De fato, todas as fêmeas bovinas deste experimento apresentaram hiperglicemia 1 hora após o parto, independente da condição obstétrica. Ainda, o Grupo EUT apresentou elevação significativa do cortisol sérico já no intra-parto, enquanto nos Grupos DIST e OCT tal mudança ocorreu no pós-parto imediato. Portanto, nota-se que o efeito hiperglicemiante do estresse é mais precoce nas fêmeas em distocia, pois a elevação nos níveis de glicose também foi observada no pós-parto imediato. Desta forma, a resposta orgânica e hormonal depende da severidade e da duração do parto (HYDBRING et al., 1999).

Neste experimento, evidenciou-se correlação positiva dos níveis de cortisol e glicemia no Grupo DIST. Entretanto, é importante ressaltar que as fêmeas deste grupo também apresentaram níveis glicêmicos estatisticamente superiores ao grupo de eutocia no intra-parto, inclusive já em hiperglicemia. Tal resultado não pode ser atribuído exclusivamente ao estresse do parto, e sim à maior mobilização de glicose hepática como substrato energético para contrações uterinas expulsivas e intensas. O perfil diferenciado da glicemia observado no Grupo DIST permite inferir que a distocia é considerada um fator agravante para a hiperglicemia de estresse. Ainda, a elevação de glicocorticóides pode ser comumente associada a picos hipertensivos (HORWITZ; HORWITZ, 1982). Durante o parto, as vacas do Grupo DIST apresentaram aumento significativo da pressão arterial, assim como maiores concentrações de cortisol no pós-parto imediato.

Durante a passagem do feto pelo canal vaginal, os níveis de glicocorticóides maternos aumentam significativamente (LANDIM-ALVARENGA, 2006). Em novilhas, a concentração de cortisol eleva-se durante a expulsão do bezerro e atinge um pico após o nascimento, porém sem distinção do perfil de estresse entre partos assistidos ou não (HYDBRING et al., 1999). Contrariamente, neste estudo, as fêmeas que necessitaram de auxílio obstétrico (Grupo DIST) apresentaram concentrações de cortisol superiores aos demais grupos logo após o parto, sinalizando que o pico de estresse decorre da intensa manobra de extração. Burton et al. (2006) corroboram tais achados, pois indicam que as distocias por estenose vulvar ou cervical podem promover maior condição de estresse com conseqüente prolongamento do parto.

As fêmeas submetidas à infusão de ocitocina apresentaram hiperglicemia apenas 1 hora após o parto, porém com níveis glicêmicos estatisticamente inferiores 
aos demais grupos. A inércia uterina deste grupo exige menor mobilização de glicose hepática. No entanto, o perfil de cortisol assemelhou-se ao grupo em eutocia. Portanto, em bovinos, a potencialização do estresse promovida pela ocitocina, anteriormente descrita em humanos (OCHEDALSKI et al., 2001) não foi verificada, bem como o efeito hiperglicemiante descrito por Wallin et al. (1989).

Todos os neonatos avaliados apresentaram-se normoglicêmicos nos dois momentos de avaliação. A manutenção da homeostase de glicose imediatamente após o parto é dependente dos estoques de glicogênio hepático, os quais devem ser suficientes para fornecer energia antes da amamentação. Quando a nutrição materna é adequada, a disponibilidade neonatal de glicose é suficiente para as necessidades iniciais (LANDIM-ALVARENGA, 2006). A assistência ao parto não determinou alterações na glicemia dos bezerros, demonstrando que a distocia não interfere com sua mobilização energética. De fato, neste experimento, não foi possível estabelecer correlação entre a glicemia dos neonatos e os teores de cortisol, mesmo em bezerros nascidos com auxílio obstétrico (Grupo DIST). Chan et al. (1993) não verificaram relação entre a função hepática de bezerros e a condição obstétrica ao nascimento.

Por outro lado, Massip (1980) verificou que bezerros submetidos ao estresse do parto assistido, hipoxemia intra-parto ou baixas temperaturas ambientais apresentam altas concentrações de glicose. Nos neonatos do Grupo DIST, o maior estresse gerado pela intensa força de extração fetal foi confirmado por maiores concentrações de cortisol ao nascimento. A longa permanência do bezerro no canal de parto, além da dificuldade para a extração forçada com auxílio de correntes obstétricas contribuíram significativamente para o aumento do estresse neste grupo.

As glândulas adrenais secretam corticosteróides como resposta à acidemia e hipóxia no momento do parto (MASSIP, 1980). De fato, verificou-se que os neonatos do Grupo DIST apresentaram simultaneamente os maiores valores de cortisol e o menor pH sangüíneo ao nascimento. É possível sugerir que a distocia induz maior liberação de adrenalina e noradrenalina em bezerros, em função do trauma causado pela intensa força de extração. A produção de catecolaminas, como indicadores de estresse, é essencial para induzir os efeitos compensatórios da acidemia estabelecida (CHAN et al., 1993).

A recuperação do estresse neonatal verificado ao nascimento ocorre 
rapidamente durante as primeiras horas de vida. Após este período inicial de adaptação, a queda nas concentrações de cortisol é mais lenta, em até 48 horas do parto (HOYER et al., 1990). Já Benesi (1992) observou valores máximos de glicocorticóides em bezerros apenas após 1 hora e decréscimo significativo a partir de 6 horas do nascimento. No presente estudo, o decréscimo dos níveis de cortisol no Grupo DIST ocorreu durante a primeira hora de vida, momento no qual não se observa diferença significativa com o grupo em eutocia.

Os bezerros do Grupo OCT, nascidos sob influência da ocitocina exógena, apresentaram glicemia e concentração de cortisol semelhantes ao Grupo EUT, tanto ao nascimento como após 60 minutos de vida. Por outro lado, potros neonatos apresentam concentrações crescentes de cortisol durante a primeira hora de vida quando o parto foi assistido com administração de ocitocina (MACPHERSON et al., 1997). Para Lúcio (2008), neonatos caninos nascidos em eutocia apresentam concentrações de cortisol similares aos nascidos sob influência de ocitocina exógena. Desta forma, a infusão de ocitocina em vacas com hipotonia ou atonia uterina neste experimento induziu a progressão fetal no canal de parto, reduzindo o grau de estresse neonatal de forma semelhante ao grupo eutocia. 
Conclusão

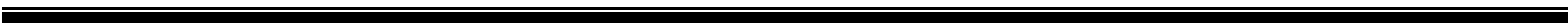




\section{CONCLUSÃO}

Com base nos resultados obtidos, pode-se concluir que:

1) A distocia com correção manual eleva a pressão arterial das fêmeas bovinas, enquanto a administração de ocitocina reduz momentaneamente a freqüência cardíaca e a pressão arterial, impondo assistência neonatal criteriosa em ambas condições.

2) Os bezerros oriundos de partos laboriosos apresentam acidose mista e importante alteração metabólica, com redução da vitalidade ao nascimento. Os bezerros sob influência da ocitocina exógena apresentam alteração respiratória e eletrolítica significativa, mas sem comprometimento do padrão de vitalidade ao nascimento.

3) As fêmeas bovinas e os bezerros submetidos à assistência obstétrica moderada a intensa demonstram maior estresse imediatamente após o parto, representado por elevação nas concentrações de cortisol e glicose sangüíneos.

4) Foi possível sugerir parâmetros laboratoriais para sangue arterial $\left(\mathrm{TCO}_{2} \mathrm{e}\right.$ Anion Gap) de bezerros hígidos, nascidos em eutocia. 
Considerações finais 


\section{CONSIDERAÇÕES FINAIS}

A área de Neonatologia é relativamente recente, mesmo na Medicina. Importantes avanços tem sido alcançados, frente à importância dos recém-nascidos no âmbito familiar, além do acurado controle de saúde pública. Entretanto, não se observa o mesmo perfil de estudos em Medicina Veterinária. Não obstante o desenvolvimento da saúde animal, ainda impera a idéia de fatalidade diante da perda, mesmo com prejuízos econômicos ou sociais. O conformismo de médicos veterinários, proprietários e pecuaristas é conseqüência da mentalidade desacreditada que se vinculou à profissão com o passar dos anos. A atuação na área de Neonatologia representa, neste aspecto, uma mudança no cenário da Medicina Veterinária. Passa-se, desta maneira, a encarar os indivíduos como pacientes, sejam eles de qualquer faixa etária. Desta forma, as pesquisas na área podem fornecer novos conhecimentos para o progresso de médicos veterinários na assistência médica aos neonatos e aos cuidados maternos.

Os resultados deste estudo denotam que as especificidades do período neonatal devem ser respeitadas e adotadas na prática médica. Ademais, neonatos de diferentes espécies apresentam particularidades que excluem o emprego de uma conduta globalizada. A adoção de um sistema exeqüível de avaliação neonatal deverá ter por base: o escore Apgar de vitalidade neonatal, adaptado à Medicina Veterinária, utilizado para discriminar neonatos hígidos e comprometidos; e análises subsidiárias que permitem não somente definir o diagnóstico, como preconizar medidas corretivas. Ainda, o recém-nascido merece atenção médica não exclusivamente no momento do parto e sim durante toda a fase adaptativa, com o objetivo de certificar que este período transcorrerá sem irregularidades.

A harmonização dos sistemas cardiovasculares e hemodinâmicos na fêmea gestante garante a higidez no momento do parto e aumenta a chance de vitalidade neonatal. Os referidos períodos fisiológicos determinam correções intrínsecas que, quando ausentes, potencializam as alterações maternas e neonatais. Por este motivo, a instituição do acompanhamento pré-natal deve ser prática rotineira em Obstetrícia Veterinária. A medida terapêutica diante de uma afecção do parto pode definir a conduta de assistência ao neonato. A terapia exógena com ocitocina pode ser considerada segura e eficaz para os casos de inércia uterina em fêmeas 
bovinas, no entanto, requer assistência materna e neonatal mais criteriosa. A condição obstétrica ao nascimento é crítica para o desempenho clínico do neonato, comprometendo sua vitalidade inicial e influenciando a circulação materno-fetal.

Esta pesquisa suscitou relevantes informações clínicas em Neonatologia Veterinária. Entretanto, diversas indagações científicas ainda persistem ou emergiram. As futuras pesquisas nesta área devem priorizar a obtenção de novos conhecimentos fisiológicos do período, simultaneamente à contribuição para o estabelecimento de padrões de conduta para a fêmea gestante, parturiente e o recém-nascido. 
Referências

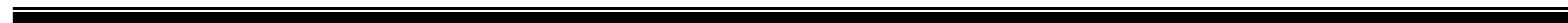




\section{REFERÊNCIAS}

ABITBOL, M. M.; MONHEIT, A. G.; STONE, M. L. Arterial PO2, PCO2, and pH versus transcutaneous $\mathrm{PO} 2$ and $\mathrm{PCO} 2$ and tissue $\mathrm{pH}$ in the fetal dog. Journal of Obstetrics and Gynecology, v.155, n.2, p.437-443, 1986.

ADAMS, R.; GARRY, F. B.; ALDRIDGE, B. M.; HOLLAND, M. D.; ODDE, K. G. Physiologic differences between twin and single born beef calves in the first two days of life. Cornell Veterinary, v.83, p.13-29, 1993.

ANDRES, R. L.; SAADE, G.; GILSTRAP, L. C.; WILKINS, I.; WITLIN, A.; ZLATNIK, F.; HANKINS, G. V. Association between umbilical blood gas parameters and neonatal morbidity and death in neonates with pathologic fetal acidemia. American Journal of Obstetrics and Gynecology, v. 181, p. 867-871, 1999.

ARTHUR, P. F.; ARCHER, J. A.; MELVILLE, G. J. Factors influencing dystocia and prediction of dystocia in Angus heifers selected for yearling growth rate. Australian Journal of Agricultural Research, v.51, p.147-153, 2000.

BATCHELDER, C. A.; BERTOLINI, M.; MASON, J. B.; MOYER, A. L.; HOFFERT, K. A.; PETKOV, S. G.; FAMULA, T. R.; ANGELOS, J.; GEORGE, L. W.; ANDERSON, G. B. Perinatal physiology in cloned and normal calves: physical and clinical characteristics. Cloning and stem cells, v.9, n.1, p.63-83, 2007.

BELLOWS, R. A.; LAMMOGLIA, M. A. Effects of severity of dystocia on cold tolerance and serum concentrations of glucose and cortisol in neonatal beef calves. Theriogenology, v.53, n.3, p.803-013, 2000.

BENESI, F. J. Hematologia de bezerros recém-nascidos. Influência da asfixia neonatal, do tipo de parto e da ingestão de colostro sobre a crase sangüínea. 1992. 126p. Tese (Livre-docência) - Faculdade de Medicina Veterinária e Zootecnia, Universidade de São Paulo, São Paulo, 1992.

BLEUL, U.; LEJEUNE, S.; SCHWANTAG, S.; KAHN, W. Blood gas and acid-base analysis of arterial blood in 57 newborn calves. Veterinary Records, v.161, p.688691, 2007.

BLEUL, U.; SCHWANTAG, S.; KAHN, W. Blood gas analysis of bovine fetal capillary blood during satge II labor. Theriogenology, v.69, p.245-251, 2008. 
BROOKS, V. L.; KEIL, L. C. Changes in the baroreflex during pregnancy in conscious dog:heart rate and hormonal responses. Endocrinology, v.135, n.5, p. 1894-1901, 1994.

BURTON, J. L.; WEBER, P. S. D.; BUSH, A. A.; NEUDER, L. et al. Parturient steroids and labor duration associated with distocia and stillbirth. Journal of Dairy Science, v.89, p.8, 2006. Supplement, 1.

CABBAD, M. F.; MINKOFF, H.; FAUSTIN, D. Fetal heart rate decelerations after oxytocin infusion in an abdominal pregnancy. Obstetrics and Gynecology, v. 66, n. 3, p. 2S-4S, 1985.

CAIN, D. V.; DENNIS, S. M. Perinatal calf mortality. Agri Practice, v.8, p.11, 1987.

CARSTENS, G. E. Cold thermoregulation in the newborn calf. In: HUNT, E. Perinatal mortality in beef herds. Veterinary Clinics of North America: Food Animal Practice, v.10, n.1, p.69-106, 1994.

CHAN, W. W.; LONKER, F. H.; RAUSCH, W. D.; TAVERNE, M. A. M. Plasma catecholamines and blood chemistry in newborn calves in relation to different obstetrical procedures and to neonatal outcome. Animal Reproduction Science, v.34, n.1, p.43-54, 1993.

CLAXTON, M. S. Electrocardiographic evaluation of arrhythmias in six cattle.

Journal of American Veterinary Medical Association, v.192, n.4, p.516-521, 1988.

COELHO, C. S. Avaliação da função renal, do metabolismo ósseo e do equilíbrio hidroeletrolítico em bezerras sadias, da raça Holandesa, no primeiro mês de vida. Influência do fator etário. 2002. 125p. Dissertação - Faculdade de Medicina Veterinária e Zootecnia, Universidade de São Paulo, São Paulo, 2002.

DAVIDSON, A. P. Approaches to reducing neonatal mortality in dogs. In: CONCANNON, P. W.; ENGLAND, G.; VERSTEGEN, J.; LINDE-FORSBERG, C. Recent advances in small animal reproduction. New York: International Veterinary Information Service, 2003. Disponível em: <http//: www.ivis.org/advances/concannon/Davidson/chapter frm.asp? LA=1>. Acesso em 05 de maio de 2006.

DEROTH, L. Electrocardiographic parameters in the normal lactating Holstein cow. Canadian Veterinary Journal, v.21, p.271-77, 1980. 
DIBARTOLA, S. P.; MORAIS, H. A. Disorders of potassium: hypokalemia and hiperkalemia. In: DIBARTOLA, S. P. Fluid, eletrolyte, and acid-base disoders in small animal pratice. 3. ed. Missouri: Saunders Elsevier, 2006. p. 91-121.

DIESCH, T. J.; MELLOR, D. J.; STAFFORD, K. J.; WARD, R. N. The physiological and physical status of single calves at birth in dairy herd in New Zealand. New Zealand Veterinary Journal, v.52, n.5, p.250-255, 2004.

DUCSAY, C. A. Fetal and maternal adaptations to chronic hypoxia: prevention of premature labor in response to chronic stress. Comparative Biochemistry and Physiology, v.119A, n.3, p.675-681, 1998.

ESSLEMONT, R. J.; PEELER, E. J. The scope for raising margins in dairy herds by improving fertility and health. British Veterinary Journal , v.149, n.6, p.537-547, 1993.

FAGLIARI, J. J.; SANTANA, A. E.; MARCHIO, W.; CAMPOS FILHO, E.; CURI, P. R. Constituintes sangüíneos de vacas das raças Nelore (Bos indicus) e Holandesa (Bos taurus) e de bubalinas (Bubalus bubalis) da raça Murrah durante a gestação, no dia do parto e no puerpério. Arquivo Brasileiro de Medicina Veterinária e Zootecnia, v.50, n.3, p.273-282, 1998.

GILBERT, R. O.; SCHWARK, W. S. Pharmacologic considerations in the management of peripartum conditions in the cow. In: Applied Pharmacology and therapeutics II. Veterinary Clinics of North America: Food Animal Practice, v.8, n.1, p.29-55, 1992.

GLATZ, T. H.; WEITZMAN, R. E.; ELIOT, R. J.; KLEIN, A. H.; NATHANIELSZ, P. W.; FISHER, D. A. Ovine maternal and fetal plasma oxytocin concentrations before and during parturition. Endocrinology, v.108, n.4, p.1328-1332, 1981.

GREENE, S. A. Anesthesic considerations for surgery of the reproductive system. Seminars in Veterinary Medicine \& Surgery: Small Animals, v.10, n.1, p.2-7, 1995.

GUTKOWSKA, J.; JANKOWSKI, M.; MUKADDAM-DAHER, S.; MCCANN, S. M. Oxytocin is a cardiovascular hormone. Brazilian Journal of Medical and Biological Research, v.33, n.6, p.625-633, 2000.

HAMLIN, R. L. Normal physiology of the cardiovascular system. In: FOX, P. R. Canine and feline cardiology. New York: Churchill Livingstone, 1988. p.15-25. 
HERPIN, P.; DIVIDICH, J. L.; HULIN, J. C.; FILLAUT, M.; DE MARCO, F.; BERTIN, $R$. Effects of the level of asphyxia during delivery on viability at birth and early postnatal vitality of newborn pigs. Journal of Animal Science, v.74, p.2067-2075, 1996.

HOMEIDA, A. M.; COOKE, R. G. Biological half-life of oxytocin in the goat. Research in Veterinary Science, v.37, p.364-375, 1984.

HORWITZ, K. B.; HORWITZ, L. D. Canine vascular tissues are targets for androgens, estrogens, progestins and glucocorticoids. Journal of Clinical Investigation, v.69, p.750-758, 1982.

HOYER, C.; GRUNERT, E.; JÖCHLE, W. Plasma glucocorticoid concentrations in calves as an indicator of stress during parturiation. American Journal of Veterinary Research, v. 15, n. 11, p. 1882-1884, 1990.

HUNTER, J. T.; FAIRCLOUGH, R. J.; PETERSON, A. J.; WELCH, R. A. Foetal and maternal hormonal changes preceding normal bovine parturition. Acta endocrinologica, n.84, v.3, p.653-662, 1977.

HYDBRING, E.; MADEJ, A.; MACDONALD, E.; DRUGGE-BOHOLM, G.; BERGLUND, B.; OLSSONM, K. Hormonal changes during parturition in heifers and goats are related to the fases and severity of labour. Journal of Endocrinology, n.160, p.75-85, 1999.

JOHNSTON, S. D.; KUSTRITZ, M. V. R.; OLSON, P. N. S. Canine Parturition Eutocia and Dystocia. In: JOHNSTON, S.D. Canine and feline theriogenology. Philadelphia: W.B. Saunders, 2001. 592p.

KANETO, F. M.; COELHO, C. S.; LEAL, M. L. R.; LISBOA, J. A. N.; BENESI, F. J. Glicemia e "anion-gap" em bezerras sadias da raça holandesa no primeiro mês de vida. Ars Veterinaria, v.20, n.3, p.291-298, 2004.

KNOTTENBELT, D. C.; HOLDSTOCK, N.; MADIGAN, J. E. Perinatal review. In: Equine neonatology. Medicine and surgery. Philadelphia: Saunders, 2006. p1-27.

LANDIM-ALVARENGA, F. C. Gestação. In: PRESTES, N. C.; LANDIMALVARENGA, F. C. Obstetrícia veterinária. Rio de Janeiro: Guanabara Koogan, 2006. p.70-81. 
LANDIM-ALVARENGA, F. C. Parto Normal. In: PRESTES, N. C.; LANDIMALVARENGA, F. C. Obstetrícia veterinária. Rio de Janeiro: Guanabara Koogan, 2006. p.82-96.

LANDIM-ALVARENGA, F. C.; PRESTES, N. C.; SANTOS, T. C. M. Manejo do neonato. In: PRESTES, N. C.; LANDIM-ALVARENGA, F. C. Obstetrícia veterinária. Rio de Janeiro: Guanabara Koogan, 2006. p.158-177.

LEFCOURT, A. M.; EREZ, B.; VARNER, M. A.; BARFIELD, R.; TASCHS, U. A noninvasive radiotelemetry system to monitor heart rate for assessing stress responses of bovines. Journal of Dairy Science, n.82, p.1179-1187, 1999.

LISBÔA, J. A. N. Equilíbrio ácido-básico em bezerras sadias da raça holandesa, no primeiro mês de vida. Influência do fator etário. 2000. 113p. Tese (Doutorado) - Faculdade de Medicina Veterinária e Zootecnia, Universidade de São Paulo, São Paulo, 2000.

LÚCIO, C. F. Influência das condições obstétricas ao nascimento sobre padrões de vitalidade e bioquímica neonatal na espécie canina. 2008. 76p. Dissertação (Mestrado) - Faculdade de Medicina Veterinária e Zootecnia, Universidade de São Paulo, São Paulo, 2008.

LUTTKUS, A. K.; STUPIN, J. H.; CALLSEN, T. A.; DUDENHAUSEN, J. W. Feasibility of simultaneous application of fetal electrocardiography and fetal pulse oximetry. Acta Obstetrica Gynecologica Scandinavica, v. 82, n. 5, p. 443-448, 2003.

MACINTIRE, D. K. Pediatric intensive care. In: Pediatrics: Puppies and Kittens. Veterinary Clinics of North America: Small Animal Practice, W.S. Saunders Company, v.29, n.4, p.971-988, 1999.

MACPHERSON, M. L.; CHAFFIN, M. K.; CARROLL, G. L.; JORGENSEN, J.; ARROTT, C.; VARNER, D. D.; BLANCHARD, T. L. Three methods of oxytocininduced parturition and their effects on foals. Journal of the American Veterinary Medical Association, v.210, p.799-803, 1997.

MANGURKAR, B. R.; HAYES, J. F.; MOXLEY, J. E. Effects of calving ease: calf survival on production and reproduction in Holsteins. Journal of Dairy Science, v.67, p.1496-1509, 1984. 
MARQUES JUNIOR, A. P.; CASTILLO CASTILLO, O. A. Glicose e triglicérides plasmáticos de vacas holandesas próximo ao parto e no puerpério. Arquivos Brasileiros de Medicina Veterinária e Zootecnia, v.48, n.3, p.309-315, 1996.

MASSIP, A. Relationship between $\mathrm{pH}$, plasma, cortisol and glucose concentrations in the calf at birth. British Veterinary Journal, v.136, n.6, p.597-601, 1980.

MEE, J. F. Prevalence and risk factors for distocia in dairy cattle: a review. The Veterinary Journal, v.176, p.93-101, 2008.

MOHRI, M.; SHARIFI, S.; EIDI, S. Hematology and serum biochemistry of Holstein dairy calves: age related changes and comparison with blood composition in adults. Research in Veterinary Science, v.83, p.30-39, 2007.

MOON, P. F.; MASSAT, B. J.; PASCOE, P. J. Neonatal critical care. Veterinary Clinics of North America: Small Animal Practice, v. 31, n. 2, p.343-366, 2001.

MOON-MASSAT, P. F.; ERB, H. N. Perioperative factors associated with puppy vigor after delivery by cesarean section. Journal of the American Hospital Association, v. 38, p.90-96, 2002.

MOORE. J. N. Dor. In: SMITH, B. P. Medicina Interna de grandes animais. 3. ed. Barueri: Manole, 2006. p. 27-35.

MORTIMER, R. G.; TOOMBS, R. E. Abnormal bovine parturition. Obstetrics and fetotomy. Female bovine infertility. Veterinary Clinics of North America: Food Animal Practice, v.9, n.2, p.323-341, 1993.

MUKADDAM-DAHER, S.; YIN, Y.L.; ROY, J.; GUTKOWSKA, J.; CARDINAL, R. Negative inotropic and chronotropic effetcs of oxytocin. Hypertension, v.38, n.2, p.292-296, 2001.

MUNCK, A.; GUYRE, P. M.; HOLBROOK, N. J. Physiological functions of glucocorticoids in stress and their relations to pharmacological actions. Endocrine Reviews, v.5, p.25-44, 1984. 
MUNIZ, L. M. R. Relação entre os níveis séricos de cortisol, T3 livre e total, T4 livre e total e a contagem de ovos por grama de fezes (OPG) de ovinos da raça Suffolk e Ideal no final da gestação, durante a lactação e após o desmame. 2001. 77f. Tese - Faculdade de Medicina Veterinária e Zootecnia, Universidade Estadual Paulista "Júlio de Mesquita Filho", Botucatu, 2001.

NIX, J. M.; SPITZER, J. C.; GRIMES, L. W.; BURNS, G. L.; PLYLER, B. B. A retrospective analysis of factors contributing to calf mortality and dystocia in beef cattle. Theriogenology, v.49, p.1515-1523, 1998.

NOAKES, D. E. Maternal distocia: causes and treatment. In: NOAKES, D. E.; PARKINSON, T. J.; ENGLAND, G. C. W. Arthur's veterinary reproduction and obstetrics. $8^{\text {th }}$ ed, London: W.B. Saunders, 2001. p.219-227.

NOAKES, D. E. The puerperium and the care of the newborn. In: NOAKES, D. E.; PARKINSON, T. J.; ENGLAND, G. C. W. Arthur's veterinary reproduction and obstetrics. $8^{\text {th }}$ ed, London: W.B. Saunders, 2001. p.189-202.

NOREN, H.; AMER-WAHLIN, I.; HAGBERG, H.; HERBST, A.; KJELLMER, I.; MARSAL, K.; OLOFSSON, P.; ROSEN, K. G. Fetal electrocardiography in labor and neonatal outcome: Data from the Swedish randomized controlled trial on intrapartum fetal monitoring. American Journal of Obstetrics and Gynecology, v.188, n.1, p.183-192, 2003.

OCHEDALSKI, T.; ZYLINSKA, K.; LAUDANSKI, T.; LACHOWICZ, A. Corticotrophinreleasing hormone and $\mathrm{ACTH}$ levels in maternal and fetal blood during spontaneous and oxytocin-induced labour. European Journal of Endocrinology, v.144, n.2, p.117-121, 2001.

ODDE, K. G. Survival of the neonatal calf. Veterinary Clinics of North America: Food Animal Practice, v.4, p.501, 1988.

OLIVEIRA, A. I. F. Reanimação na Sala de Parto. In: JÁCOMO, A. J. D.; JOAQUIM, M. C. M.; LISBOA, A. M. J. Assistência ao recém-nascido. Normas e rotinas. São Paulo: Atheneu, 1999. p.29.

OLSSON. K.; HYDBRING, E.; CVEK, K. Cardiovascular and fluid regulatory mechanisms during pregnancy and lactation in small ruminant. Trends Comparative Biochemistry and Physiology, v.5, p.283-296, 1998. 
PATTERSON, D. J.; BELLOWS, R. A.; BURFENING, P. J.; CARR, J. B. Ocurrence of neonatal and postnatal mortality in range beef cattle. I. Calf loss incidence from birth to weaning, backward and breech presentation and effects of calf loss on subsequent pregnancy rate of dams. Theriogenology, v.28, n.5, p.557-571, 1987.

PATTESON, M. Electrophysiology and arrhythmogenesis. In: MARR, C. M. Cardiology of the horse. 1 ed. Philadephia: W.B. Saunders, 1999. p.51-69.

PATTON, H. D.; HOWELL, W. H.. Textbook of physiology: circulation, respiration, body fluids, metabolisms and endocrinology, 21 ed. Philadelphia: W.B. Saunders, 1989. p.1391-1399.

PCAPS. Prefeitura do Campus de Pirassununga. Universidade de São Paulo.Estação metereológica. Disponível em: < http://www.usp.br/pcaps >. Acesso em 31 jul 2008.

PINEDA, M. H. McDonald's veterinary endocrinology and reproduction. lowa: lowa State Press, 2003. 597p.

POGLIANI, F. C. Valores de referência e influência dos fatores etários, sexuais e da gestação no lipidograma de bovinos da raça Holandesa, criados no Estado de São Paulo. 2006. 134p. Dissertação (Mestrado) - Faculdade de Medicina Veterinária e Zootecnia, Universidade de São Paulo, São Paulo, 2006.

PONTES JR, S. C.; ANDRADE, M. M. Mudanças cardiocirculatórias maternas no período gestacional. In: ANDRADE, J. Patologias cardíacas da gestação. São Paulo: Edusp, 2000. p.280.

RADOSTITS, O. M.; GAY, C. C.; BLOOD, D. C.; HINCHCLIFF, K. W. Clínica Veterinária. Um tratado de doenças dos bovinos, ovinos, suínos, caprinos e eqüinos. 9.ed. Rio de Janeiro: Guanabara Koogan, 2002, 1737p.

REEF, V. B.; MCGUIRK, S. M. Doenças do sistema cardiovascular. In: SMITH, B. P. Medicina interna de grandes animais. 3. ed. Barueri: Manole, 2006. p. 443.

RICE, L. E. Dystocia-related risk factors. In: KASARI, T. R.; WIKSE, S. E. Perinatal mortality in beef herds. Veterinary Clinics of North America: Food Animal Practice, v.10, n.1, p.53-68, 1994. 
RICHARDSON, B.; CARMICHAEL, L.; HOMAN, J.; PATRICK, J. E. Cerebral oxidative metabolism in fetal sheep with prolonged and graded hypoxemia. Journal Development Physiology, v.19, n.2, p.77-83, 1993.

RILEY, D. G.; CHASE, C. C.; OLSON, T. A.; COLEMAN, S. W.; HAMMOND, A. C. Genetic and nongenetic influences on vigor at birth and preweaning mortality of purebred and high percentage Brahman calves. Journal of Animal Science, v.82, p.1581-1588, 2004.

ROBINSON, N. E. Homeostase. Homeostase ácido-básica. In: CUNNINGHAM, J. G. Tratado de fisiologia veterinária. 3. ed. Rio de Janeiro: Guanabara-Koogan, 2004. p.533-549.

SALHAB, W. A.; WYCKOFF, M. H.; LAPTOOK, A. R.; PERLMAN, J. M. Initial hypoglycemia and neonatal brain injury in term infants with severe fetal acidemia Pediatrics, v.114, p.361-366, 2004.

SIRISTATIDIS, C.; SALAMALEKIS, E.; KASSANOS, D.; LOGHIS, C.; CREATSAS, G. Evaluation of fetal intrapartum hypoxia by middle cerebral and umbilical artery Doppler velocimetry with simultaneous cardiotocography and pulse oximetry. Archives of Gynecology and Obstetrics, v.270, n.4, p.265-270, 2003.

SOUSA, J. M. A.; HERMANN, J. L. V.; GUIMARÃES, J. B.; MENEZES, P. P. O.; CARVALHO, A. C. C. Avaliação das pressões sistólica, diastólica e pressão de pulso como fator de risco para doenças aterosclerótica coronariana grave em mulheres com angina instável u infarto agudo do miocárdio sem supradesnivelamento do segmento ST. Arquivos Brasileiros de Cardiologia, v.82, n.5, p.426-429, 2004.

SAS. STATISTICAL ANALISYS SYSTEM. System for Windows, Cary, NC, USA, 2000.

STEPHENSON, R. B. Fisiologia cardiovascular. Controle neural e hormonal da pressão sangüínea e do volume sangüíneo. In: CUNNINGHAM, J. G. Tratado de fisiologia veterinária. 3 ed. Rio de Janeiro: Guanabara-Koogan, 2004. p.208-217.

SWENSON, M. J.; REECE, W. O. Dukes fisiologia dos animais domésticos. Rio de Janeiro: Guanabara Koogan, 1996. 902p. 
TAVERNE, M. A. M.; SCHWARTZ, N. C. M.; KANKOFER, M.; BEVERS, M. M.; VAN OORD, H. A.; SCHAMS, D. Uterine responses to exogenous oxytocin before and after pre-partum luteolysis in the cow. Reproduction in Domestic Animals, v.36, p.267-272, 2001.

VAALA, W. E.; HOUSE, J. K.; MADIGAN, J. E. Parte três. Distúrbios e tratamento do neonato. In: SMITH, B. P. Medicina interna de grandes animais. 3 ed. Barueri: Manole, 2006. p. 255-386.

WALLIN, L. A.; FAWCETT, C. P.; ROSENFELD, C. R. Oxytocin stilumates glucagons and insulin secretion in fetal and neonatal sheep. Endocrinology, v.125, n.5, p.2289-2296, 1989.

WIKSE, S. E.; KINSEL, M. L.; FIELD, R. W.; HOLLAND, P. S. Investigating perinatal calf mortality in beef herds. Veterinary Clinics of North America: Food Animal Practice, v.10, n.1, p.147-166, 1994.

WITTUN, T. E.; SALMAN, M. D.; ODDE, K. G.; MORTIMER, R. G.; KING, M. E. Causes and costs of calf mortality in Colorado beef herds participating in the National Animal Health Monitoring System. Journal of American Veterinary Medical Association, v.203, n.2, p.232-236, 1993.

YEOMANS, E. R.; HAUTH, J. C.; GILSTRAP, L. C.; STRICKLAND, D. M. Umbilical cord $\mathrm{pH}, \mathrm{PCO}_{2}$ and bicarbonate following uncomplicated term vaginal deliveries. American Journal of Obstetrics and Gynecology, v.151, p.798-800, 1985. 